\title{
GESTÃO POR PROCESSOS EM UMA EMPRESA DE PESQUISA E DESENVOLVIMENTO: OBJETIVO ESTRATÉGICO DE UM MODELO DE GESTÃO
}

Odemilson Fernando Sentanin

Dissertação apresentada à Escola de Engenharia de São Carlos da Universidade de São Paulo, como parte dos requisitos para a obtenção do Título de Mestre em Engenharia de Produção.

Orientador: Prof. Dr. Fernando César Almada Santos

São Carlos

2004 
A Deus, fonte de vida, por intercessão de Nossa Senhora Aparecida. 
Dedico este trabalho aos meus pais Izael e Maria José, à minha esposa Elisângela e ao meu irmão Oelcio, pela paciência, ajuda, conselhos, confiança, incentivos e amor que deles recebi. 


\section{AGRADECIMENTOS}

Ao Professor Doutor Fernando César Almada Santos, por todo seu apoio, paciência e orientação durante o desenvolvimento deste trabalho.

Ao Doutor Ladislau Martin Neto, Chefe Geral da Embrapa Instrumentação Agropecuária, por acreditar em meu potencial, pela oportunidade e incentivo.

Ao Doutor Álvaro Macedo da Silva, pela compreensão e auxílio.

À Professora Doutora Ruth de Gouvêa Duarte, minha “mãe acadêmica”, pelo incentivo e constante apoio.

Ao meu amigo Luiz Fernando Ferreira, pela atenção e incentivo.

Ao Professor Doutor Renato Vairo Belhot, pelo grande auxílio no início deste trabalho.

Ao Professor Doutor Edmundo Escrivão Filho, pelas valiosas explanações e reflexões.

Aos demais funcionários do Departamento de Engenharia de Produção, especialmente José Luiz Donizetti Chiaretto, pelo apoio e atenção.

Aos funcionários da Embrapa Instrumentação Agropecuária, pelo apoio.

Ao Ednaldo José Ferreira, pelas constantes discussões sobre pós-graduação.

A todos que, de forma direta e indiretamente, contribuíram para a realização deste trabalho.

Agradeço a todos. Meu muito obrigado. 


\section{RESUMO}

SENTANIN, O.F. (2004). Gestão por processos em uma empresa de pesquisa e desenvolvimento: objetivo estratégico de um modelo de gestão. Dissertação (Mestrado) - Escola de Engenharia de São Carlos, Universidade de São Paulo, São Carlos, 2004.

Esta dissertação tem por objetivo avaliar a gestão por processos em uma empresa de pesquisa e desenvolvimento como um dos objetivos estratégicos de seu modelo de gestão, bem como identificar seu nível de evolução e características em relação a uma empresa orientada por processos. O presente estudo de caso foi realizado no Centro Nacional de Pesquisa e Desenvolvimento de Instrumentação Agropecuária - CNPDIA, uma das quarenta unidades de pesquisa da Empresa Brasileira de Pesquisa Agropecuária Embrapa, instituição de pesquisa e desenvolvimento vinculada ao Ministério da Agricultura, Pecuária e Abastecimento, uma das maiores instituições de pesquisa do mundo tropical, presente em quase todos os Estados da Federação, nas mais diferentes condições ecológicas, contribuindo para o sucesso do agronegócio e do desenvolvimento sustentável. Realizou-se uma revisão bibliográfica sobre a importância da gestão por processos dentro de uma visão estratégica, as principais diferenças entre uma empresa estruturada por função e estruturada por processos e também as principais dificuldades de uma transição para processos. Por meio da análise de documentos e relatórios apresentados pela empresa, entrevistas relacionadas ao tema com gerentes e funcionários da empresa, e estudo do Modelo de Gestão Estratégica - MGE - adotado, no qual insere-se a gestão por processos como um de seus objetivos estratégicos e confrontando com a teoria, este estudo de caso avaliou como a empresa está se estruturando para atender às necessidades e desafios apresentados nesse contexto de mudanças, os quais forçam as organizações a reavaliarem e readequarem seus modelos de gestão e suas estruturas organizacionais para conseguirem manterem-se vivas nesse ambiente competitivo. Os resultados obtidos nesta pesquisa demonstram que a unidade, apesar de apresentar vários indicativos de mudança de estrutura organizacional para modelos mais flexíveis, está passando por uma fase de transição, caracterizando um aprendizado para todos os envolvidos e, principalmente, que as resistências apresentadas a esse novo modelo de gestão proposto estão sendo reduzidas por conseqüência da internalização dos conceitos e do maior conhecimento, por parte dos executivos e funcionários, sobre a abordagem de processos.

Palavras-chave: gestão estratégica, planejamento estratégico, gestão por processos. 


\begin{abstract}
SENTANIN, O.F. (2004). Process management in a research company and development: strategic objective of a management model. M.Sc. Dissertation - Escola de Engenharia de São Carlos, Universidade de São Paulo, São Carlos, 2004.

This dissertation aims to evaluate the process management in a research and development institution as one of the strategic objectives of its management model, as well as to identify its level of evolution and characteristics in comparison to a company guided by process. The present case study was accomplished in the National Agricultural Instrumentation Research Center - CNPDIA, one of the forty units of research of the Brazilian Agricultural Research Corporation - Embrapa, research and development institution linked to the Ministry of Agriculture, Livestock and Food Supply, one of the largest institutions of research of the tropical world, present in almost all the States of the Federation, in the most different ecological conditions, contributing to the success of the agribusiness and of the maintainable development. A bibliographical revision on the importance of the process management for a strategic vision was carried out. The main differences between companies structured by function and companies structured by process and also the main difficulties of a transition for process were investigated. Through the analysis of documents and reports presented by the company, interviews related to the theme with managers and employees of the company, and the study of the Model of Strategic Management - MGE - adopted, in which interferes the process management as one of its strategic objectives and confronting with the theory, this case study evaluated as the company is structuring to meet to the needs and challenges presented in that context of changes, which force the organizations reanalyze and readjust their management models and their organizational structures to maintain itself alive in that competitive environment. The results obtained in this research demonstrate that the unit, although presenting several indicative of change of organizational structure for more flexible models, it is going by a transition phase, characterizing a learning for all involved them and, mainly, that the resistances presented to that new management model proposed they are being reduced for consequence of the adoption of the concepts and of the largest knowledge on the part of the executives and employees, on the approach of process.
\end{abstract}

Keywords: strategic management, strategic planning, process management. 


\section{LISTA DE FIGURAS}

Figura 1 - Estrutura do trabalho. 10

Figura 2 - Estrutura do Balanced Scorecard

Figura 3 - A perspectiva do cliente - medidas essenciais 26

Figura 4 - Envolvimento dos processos com o planejamento estratégico 38

Figura 5 - Estrutura do Capítulo 1 39

Figura 6 - Etapas básicas de um processo

Figura 7 - Fluxo de processos - onde os processos se encaixam em sua organização atual 43

Figura 8 - Macrofluxo do processo de negócio 47

Figura 9 - As três fases na vida de um processo de negócio 48

Figura 10 - Estrutura organizacional da Embrapa Instrumentação Agropecuária 79

Figura 11 - Modelo de gestão corporativo da Embrapa. 84

Figura 12 - Modelo de Gestão Estratégica Corporativo da Embrapa 88

Figura 13 - Processo de Gestão Estratégica na Embrapa 92

Figura 14 - Modelo de Gestão Estratégica da Embrapa Instrumentação Agropecuária 94

Figura 15 - Gestão por processos da Embrapa: arquitetura geral 97 


\section{LISTA DE QUADROS}

Quadro 1 - Premissas das escolas de prescritivas do pensamento para formulação de estratégia

Quadro 2 - Premissas das escolas descritivas do pensamento para formulação de estratégia 18

Quadro 3 - Premissas das escolas da integração do pensamento para

formulação de estratégia

Quadro 4 - Principais objetivos dos processos relacionados às perspectivas do balanced scorecard 31

Quadro 5 - Categorias básicas de processos 45

Quadro 6 - Etapas de implementação da gestão orientada por processos 51

Quadro 7 - Estrutura funcional e estrutura por processos 55

Quadro 8 - Pressupostos clássicos sobre resistência à mudança e possíveis contrapressupostos

Quadro 9 - Os estágios da evolução para a organização por processos 66

Quadro 10 - Tópicos associados à gestão por processos.

Quadro 11 - Cenários organizacionais da Embrapa 81

Quadro 12 - Visão geral da metodologia de análise e melhoria de processos (AMP) na Embrapa 100

Quadro 13 - Processos analisados e melhorados na Embrapa Instrumentação Agropecuária. 106

Quadro 14 - Estágio evolutivo da Embrapa Instrumentação Agropecuária rumo à organização por processos . 116

Quadro 15 - Análise e perspectivas para a Embrapa Instrumentação Agropecuária rumo à organização por processos 


\section{LISTA DE ABREVIATURAS}

EMBRAPA - Empresa Brasileira de Pesquisa Agropecuária

CNPDIA - Centro Nacional de Pesquisa e Desenvolvimento de Instrumentação Agropecuária

BSC - Balanced Scorecard

MGE - Modelo de Gestão Estratégica

PDE - Plano Diretor da Embrapa

PDU - Plano Diretor da Unidade

AMP - Análise e Melhoria de Processos 


\section{SUMÁRIO}

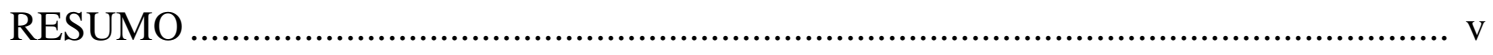

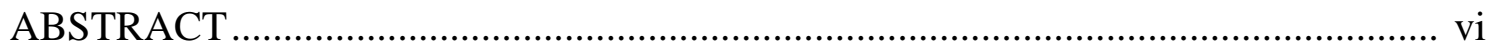

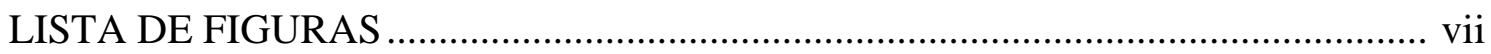

LISTA DE QUADROS .......................................................................................... viii

LISTA DE ABREVIATURAS .......................................................................... ix

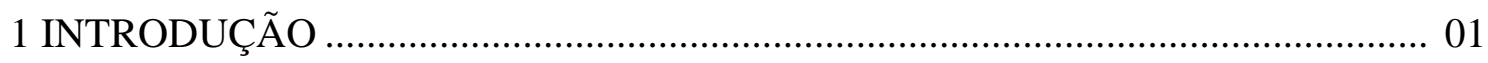

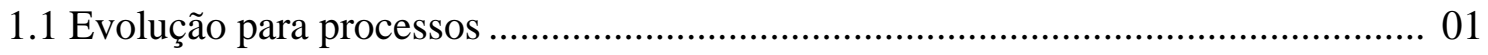

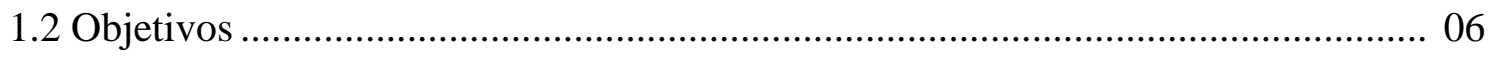

1.3 Metodologia de pesquisa................................................................................... 06

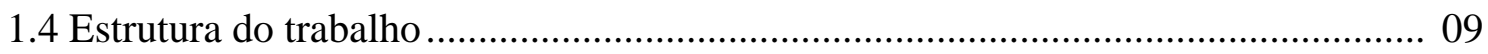

2 PLANEJAMENTO ESTRATÉGICO, MODELO DE GESTÃO ESTRATÉGICA

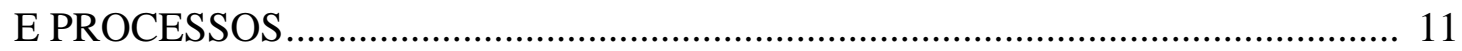

2.1 Planejamento estratégico...................................................................................... 11

2.2 Modelo de gestão estratégica: Balanced Scorecard................................................. 19

2.2.1 As quatro perspectivas do Balanced Scorecard .................................................... 23

2.2.1.1 Perspectiva financeira .................................................................................. 23

2.2.1.2 Perspectiva do cliente.................................................................................... 24

2.2.1.3 Perspectiva dos processos internos .................................................................. 26

2.2.1.4 Perspectiva do aprendizado e crescimento........................................................... 32

2.3 Planejamento estratégico e processos .................................................................... 37

2.4 Considerações finais............................................................................................. 39 


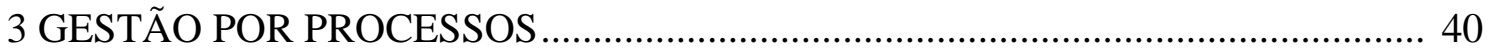

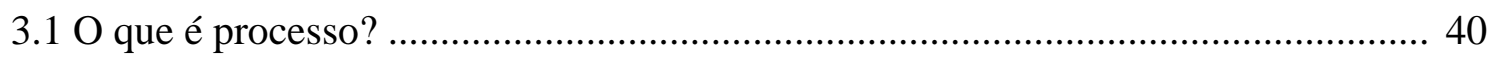

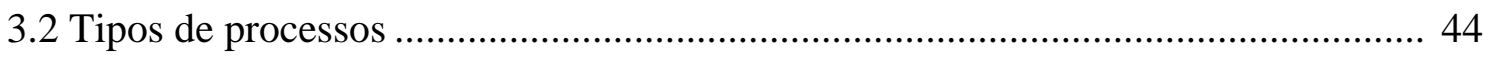

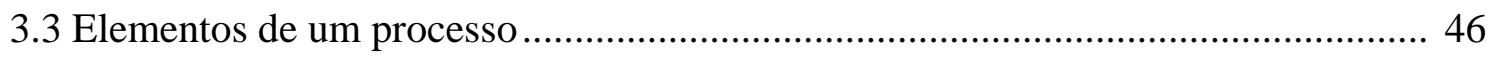

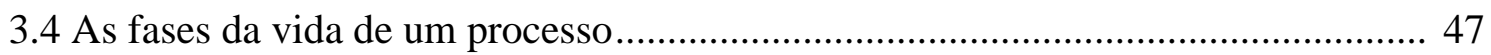

3.5 Estrutura funcional e estrutura por processos ................................................. 51

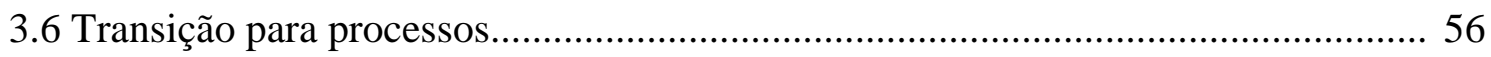

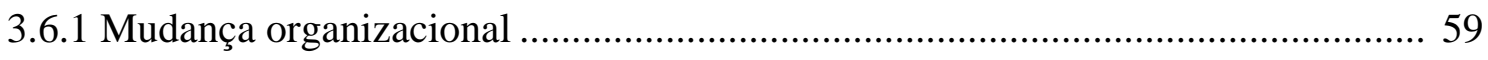

3.7 Estágios de evolução das empresas voltadas para processos .................................. 65

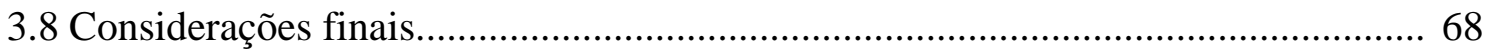

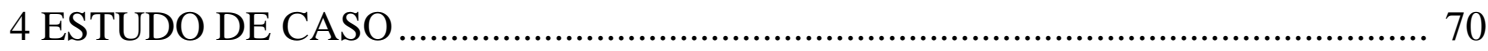

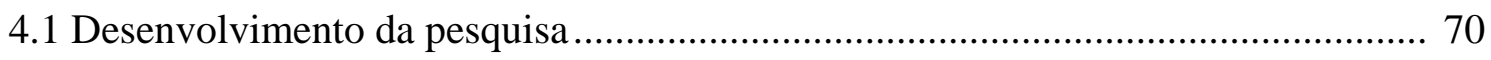

4.2 A Empresa Brasileira de Pesquisa Agropecuária - Embrapa ................................ 72

4.2.1 A Embrapa Instrumentação Agropecuária ....................................................... 77

4.3 A evolução do planejamento estratégico na Embrapa ........................................... 80

4.3.1 O planejamento estratégico na Embrapa Instrumentação Agropecuária .............. 85

4.4 O Modelo de Gestão Estratégica da Embrapa - MGE......................................... 87

4.4.1 O Modelo de Gestão Estratégica da Embrapa Instrumentação Agropecuária ...... 93

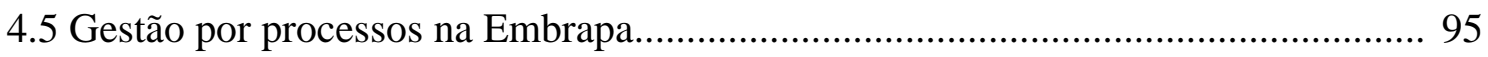

4.5.1 Metodologia de análise e melhoria de processos na Embrapa ............................. 99

4.5.2 A gestão por processos na Embrapa Instrumentação Agropecuária ................... 105

4.5.2.1 A visão de clientes para a Embrapa Instrumentação Agropecuária................. 107

4.5.2.2 A classificação dos processos na Embrapa Instrumentação Agropecuária...... 108

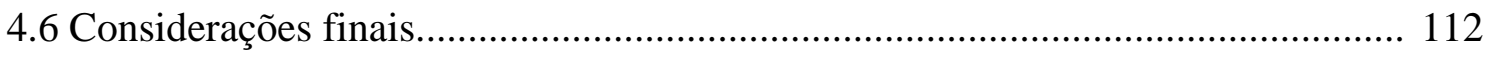


5 CONCLUSÕES

5.1 Confrontação entre teoria e prática ................................................................... 117

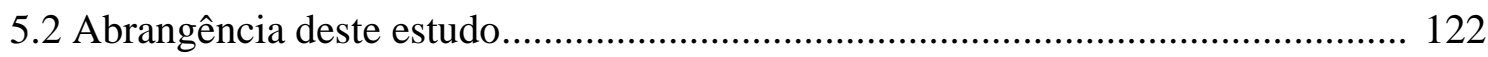

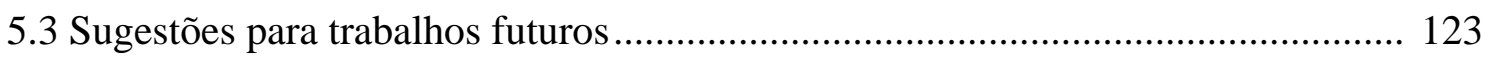

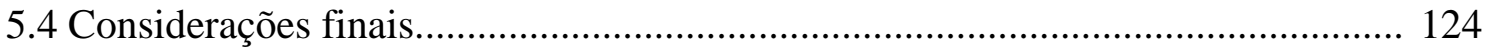

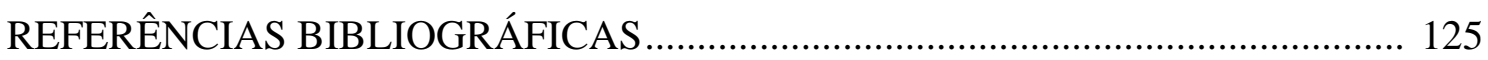

APÊNDICE 1 - Principais produtos e tecnologias da Embrapa Instrumentação

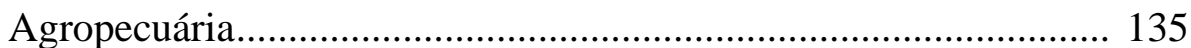

APÊNDICE 2 - Cartaz divulgado às unidades da Embrapa sobre o banco de dados de boas práticas 146 


\section{INTRODUÇÃO}

\subsection{Evolução para processos}

A saturação da demanda por bens de consumo padronizados por meio da produção em massa e a exigência, cada vez maior do consumidor, por diversificação de produtos, fez com que as empresas buscassem novas formas de produção, forçando-as a desenvolverem-se além de seu desempenho básico. O ambiente seguro em que as empresas operavam passou a ser um ambiente cada vez mais mutável e complexo.

As constantes mudanças do ambiente, provocadas pela crescente globalização da economia e pelo contínuo aparecimento de novas tecnologias, forçaram as organizações a elaborarem e aperfeiçoarem suas operações, aliando não somente a eficiência, mas também a eficácia e efetividade, com o objetivo de fazer as coisas certas, da melhor forma possível - de modo que os clientes estivessem satisfeitos com a utilização dos produtos ou serviços resultantes do processo.

Nessa nova perspectiva, o planejamento estratégico tem papel fundamental para que uma empresa possa focalizar sua atenção e recursos em objetivos definidos. Sem um claro entendimento da missão, visão e valores de um determinado negócio torna-se quase impossível criar processos para suportá-los. Com isso, direta ou indiretamente, os processos estão ligados ao planejamento estratégico de negócio. 
Para traduzir esse planejamento estratégico em objetivos específicos com medidas de desempenho, Kaplan e Norton apresentam o Balanced Scorecard. Esse modelo apresenta quatro perspectivas: financeira, de cliente, dos processos internos e do aprendizado e crescimento, as quais equilibram os objetivos de curto e longo prazos, os resultados desejados e os vetores de desempenho desses resultados, as medidas objetivas concretas e as medidas subjetivas mais imprecisas.

Ostroff e Smith (1992) destacam que, para vencer os competidores nesse mercado dinâmico, as empresas devem possuir algumas características como visão de liderança, forças de trabalho auto-gerenciadas, dedicação aos clientes, qualidade total e melhoria e inovação contínuas. No entanto, para se construir tal companhia é necessário que os gerentes se movam além de seu tradicional foco em excelência funcional, desenvolvendo novas formas organizacionais que alavanquem a coordenação através das funções de suas próprias atividades e, ainda, que as liguem fortemente aos seus fornecedores e clientes.

Nesse panorama, insere-se a perspectiva de processos que forçam as empresas a verem seu trabalho, não somente do próprio ponto de vista, mas também pelo prisma do cliente.

Campos (1998) destaca que - para serem bem sucedidas em um mercado de alta segmentação, onde a inovação, a rapidez e a qualidade são primordiais - as empresas precisam saber trabalhar em uníssono com os seus clientes, parceiros e fornecedores, em ambientes onde as funções se entrelaçam e esvanecem para dar prioridade aos processos.

Levando-se em consideração as expectativas de seus clientes, o gerenciamento efetivo de processos fundamenta-se, principalmente, em sua compreensão por parte da organização (EMPRESA BRASILEIRA DE PESQUISA AGROPECUÁRIA, 2002a).

A gestão eficiente dos processos pode permitir à organização: 
- criar condições para prever, promover e controlar mudanças institucionais;

- aperfeiçoar e maximizar o uso dos recursos disponíveis;

- dispor, de forma mais ágil, de meios para mudanças operacionais;

- desenvolver uma visão sistêmica das suas atividades;

- criar condições para uma gestão mais eficiente de suas equipes de trabalho;

- prever e minimizar a ocorrência de erros e problemas;

- compreender como as entradas (insumos) se transformam em saídas (produtos);

- definir e aplicar indicadores de desempenho do processamento e da agregação de valor;

- adotar adequados controles de custos.

Kaplan e Norton (1997) recomendam que uma cadeia de valor completa dos processos deve iniciar com o processo de inovação, no qual são identificadas as necessidades atuais e futuras dos clientes e são desenvolvidas novas soluções para essas necessidades; os processos de operações entregam os produtos e prestam serviços aos clientes existentes e, por fim, os processos de pós-vendas que complementam o valor proporcionado aos clientes pelos produtos ou serviços de uma empresa.

Por outro lado, na visão de processos, as atividades empresariais não são vistas somente como funções, departamentos ou produtos, mas sim como processos, nos quais a ênfase está na maneira como o trabalho é feito na organização.

Para Davenport (1994, p.7), “processo é uma ordenação específica das atividades de trabalho no tempo e no espaço, com um começo, um fim, e inputs e outputs claramente identificados: uma estrutura para a ação”. 
Segundo Hammer (1998), uma organização orientada para processos tem neles o centro das atenções, diferentemente das organizações tradicionais nas quais os processos são ignorados. As organizações tradicionais se baseiam no fato de os funcionários terem foco restrito e de a visão mais geral do quadro caber unicamente aos gerentes, enquanto nas organizações voltadas para processos, todos têm visão ampla com papéis maiores, trabalhando em espírito de equipe, com propósitos de alcançar determinados resultados e objetivos definidos pelo cliente. “As pessoas têm que cumprir tarefas, mas pensar a respeito de processos” (HAMMER, 1998, p.1).

A gestão por processos organizacionais difere da tradicional gestão por funções, devido a pelo menos três motivos: ela emprega objetos externos, os empregados e recursos são agrupados para produzir um trabalho completo e a informação segue diretamente para onde é necessária - sem o filtro da hierarquia (STEWART, 1992).

“Enquanto a estrutura hierárquica é, tipicamente, uma visão fragmentária e estanque das responsabilidades e das relações de subordinação, a estrutura de processo é uma visão dinâmica da forma pela qual a organização produz valor” (DAVENPORT, 1994, p.7).

Para Belmiro e Reche (2003), o principal motivo para a adoção de uma gestão orientada por processos está fundamentada na crescente necessidade de as organizações alcançarem maiores índices de desempenho e eficiência por meio de ganhos em rapidez e flexibilidade. "Espera-se que o foco no resultado viabilize melhorias contínuas nos processos internos e que uma reorientação na forma de gestão propicie uma cultura voltada para a eliminação de gargalos e redundâncias e para o questionamento contínuo da forma de se trabalhar” (BELMIRO e RECHE, 2003, p.261).

Ubeda (2003) destaca que essa reorientação na forma de gestão resulta na transformação da estrutura organizacional das empresas, forçando-as a realinharem seus processos, suas competências e seus sistemas de informação, direcionadas por seus objetivos estratégicos. "Evidencia-se o achatamento da hierarquia e a eliminação dos cargos, diminuindo o gerenciamento hierárquico, graças à tecnologia de informação que 
proporciona o desenvolvimento de equipes auto-geridas e o envolvimento dos funcionários nos processos” (UBEDA, 2003, p. 22).

Gonçalves (2000b) apresenta vários estágios na evolução de uma empresa em direção à organização por processos, desde um modelo puramente funcional até um modelo essencialmente baseado em processos, enfatizando que cada empresa pode decidir por evoluir de um estágio para outro que seja mais adequado às suas operações e perspectivas.

No entanto, a mudança para processos é muito difícil (HAMMER, 1998), pois as pessoas têm que aprender a pensar de forma diferente; têm que aprender a compreender o negócio, a assumir mais responsabilidades, a trabalhar em equipe. A tecnologia da informação tem importante papel na eficiência e eficácia desse tipo de organização voltada para processos. Para Davenport (1994, p.84), “o progresso na administração das informações raramente é descrito ou medido [...]. Grandes volumes de informações entram e saem das organizações sem que ninguém tenha plena consciência do seu impacto, valor ou custo”.

Em termos de recursos humanos, segundo Gonçalves (2000b), a gestão por processos traz inéditos desafios quanto à complexidade pois, em um quadro em que as pessoas têm grande importância na implementação das organizações estruturadas de acordo com esse modelo, surgem perguntas inquietantes para as quais ainda não foram encontradas as melhores respostas: - Como trabalham as pessoas em um processo? - A quem respondem? - Como se coordena o trabalho realizado no processo? - Como avaliar a adequação e o desempenho das pessoas na organização por processos? - Como estruturar a carreira e o desenvolvimento dessas pessoas?

Para Hammer (1997), as empresas que mantiverem suas estruturas hierárquicas tradicionais e sistemas burocráticos não serão capazes de competir com as empresas orientadas para processos. 


\subsection{Objetivos}

Tendo em vista a complexidade e as dificuldades apresentadas para a implementação de uma visão por processos, este trabalho tem por objetivo identificar o nível de evolução de uma empresa quanto à transição de uma estrutura funcional para uma visão orientada a processos.

Propõe, também, por meio de ampla revisão bibliográfica sobre o tema, confrontando teoria e prática, avaliar como a empresa está se estruturando para atender às mudanças e desafios apresentados nesse novo modelo de gestão organizacional, identificando os fatores organizacionais, contextuais e pessoais que interferem nesse processo, na busca de apresentar propostas para minimizar as diferenças entre o que é feito atualmente e o que é esperado.

Este estudo poderá servir de subsídios para ajustes e mesmo para planejamento de uma reestruturação que viabilize uma participação mais consciente, motivada e produtiva de cada indivíduo. As pessoas precisam compreender que as várias etapas de seu trabalho devem ser realizadas com uma perspectiva de integração e de foco nos clientes, para viabilizar uma gestão que otimize resultados.

\subsection{Metodologia de pesquisa}

O estudo foi realizado no Centro Nacional de Pesquisa e Desenvolvimento de Instrumentação Agropecuária - CNPDIA, uma das quarenta unidades de pesquisa da Empresa Brasileira de Pesquisa Agropecuária - Embrapa, instituição de pesquisa e desenvolvimento vinculada ao Ministério da Agricultura, Pecuária e Abastecimento, uma das maiores instituições de pesquisa do mundo tropical, presente em quase todos os Estados da Federação, nas mais diferentes condições 
ecológicas e contribuindo para o sucesso do agronegócio e do desenvolvimento sustentável.

A unidade de pesquisa da Embrapa estudada é também denominada Embrapa Instrumentação Agropecuária, nome que será adotado no decorrer deste trabalho.

A Embrapa Instrumentação Agropecuária, fundada em 1984, “caracteriza-se como uma instituição de ciência e tecnologia em instrumentação, voltada prioritariamente para o desenvolvimento econômico e social auto-sustentado do agronegócio brasileiro” (EMPRESA BRASILEIRA DE PESQUISA AGROPECUÁRIA, 2000b).

Por meio da análise de documentos e relatórios apresentados pela empresa, entrevistas relacionadas ao tema com gerentes e funcionários da empresa, e também a própria participação do pesquisador nas atividades e discussões relacionadas à metodologia de gestão proposta pela empresa, esta dissertação busca apresentar o Plano Diretor da Embrapa bem como o Plano Diretor da Unidade estudada - Embrapa Instrumentação Agropecuária, descrevendo também seu Modelo de Gestão Estratégica MGE, baseado no Balanced Scorecard, no qual insere-se a gestão por processos como um de seus objetivos estratégicos.

Conforme caracterizado, a pesquisa foi realizada em uma das unidades da Empresa Brasileira de Pesquisa Agropecuária. Rey (1993) define pesquisa como uma “investigação e estudo minudente e sistemático com o fim de descobrir ou estabelecer fatos ou princípios relativos a um campo qualquer do conhecimento”. Os métodos de pesquisa a serem utilizados variam de acordo com o campo da investigação, a natureza dos fatos ou fenômenos estudados e as circunstâncias em que se vai trabalhar.

Thiollent (2003) destaca que os métodos experimentais comuns, válidos em laboratórios, são inadequados à pesquisa em organizações reais. Devido a isso, apresenta como alternativa a pesquisa-ação. 
"Pesquisa-ação é um tipo de pesquisa social com base empírica que é concebida e realizada em estreita associação com uma ação ou com a resolução de um problema coletivo e no qual os pesquisadores e os participantes representativos da situação ou do problema estão envolvidos de modo cooperativo ou participativo" (THIOLLENT, 2003, p.14).

Seu princípio fundamental consiste na busca de soluções e, simultaneamente, no aprofundamento do conhecimento científico disponível, por parte dos pesquisadores e membros da organização envolvidos na definição do problema. Pela pesquisa-ação é possível estudar dinamicamente os problemas, decisões, ações, negociações, conflitos e tomadas de consciência que ocorrem entre os agentes durante o processo de transformação da situação (THIOLLENT, 2003).

Gil (2000) classifica as pesquisas em: pesquisas bibliográficas, pesquisa documentais, levantamentos, estudos de casos, estudos de campo e pesquisas experimentais. Para efeito deste trabalho será adotado o estudo de caso.

Segundo Yin (1989, p.23), estudo de caso “é um estudo empírico que investiga um fenômeno dentro de seu contexto de realidade, quando as fronteiras entre o fenômeno e o contexto não são claramente definidas, e no qual são utilizadas várias fontes de evidência”.

O estudo de caso tem sido utilizado com freqüência cada vez maior pelos pesquisadores sociais (GIL, 2000), visto que explora situações da vida real cujos limites não estão claramente definidos, descreve a situação do contexto da investigação e explica as variáveis causais de determinado fenômeno em situações que não possibilitam a utilização de levantamentos e experimentos.

Para Gil (2000), são necessárias algumas habilidades do pesquisador nos estudos de caso. Eles devem ter amplo conhecimento do assunto, atitude autocorretiva, habilidade para formular questões, habilidade para ouvir e interpretar.

Com a pesquisa realizada na instituição escolhida, apresentando seus instrumentos gerenciais, buscaram-se subsídios para confrontar os dados obtidos no 
estudo de caso descrito no Capítulo 4 com a revisão bibliográfica apresentada nos Capítulos 2 e 3, de modo a atingir os objetivos propostos para este trabalho.

\subsection{Estrutura do trabalho}

O Capítulo 1 apresenta a introdução desta dissertação de mestrado, contendo a contextualização do tema, objetivos, metodologia e estrutura deste trabalho.

No Capítulo 2 faz-se uma revisão bibliográfica sobre a importância da gestão por processos dentro de uma visão estratégica e qual seu papel dentro do modelo de gestão estratégica apresentado.

No Capítulo 3 caracteriza-se a gestão por processos com uma revisão bibliográfica sobre os principais itens a serem abordados como o nível de evolução de uma empresa gerida por processos, as principais diferenças entre uma empresa estruturada por funções e estruturada por processos e as dificuldades para uma transição para processos.

No Capítulo 4 realiza-se o estudo de caso, com o objetivo de avaliar a gestão por processos em uma empresa de pesquisa e desenvolvimento, como um dos objetivos estratégicos de um modelo de gestão.

O Capítulo 5 apresenta as conclusões finais deste trabalho, confrontandose a teoria apresentada nos Capítulos 2 e 3 com o estudo de caso apresentado no capítulo 4 e, também, argumenta sobre a abrangência deste estudo, bem como propõe trabalhos futuros. 


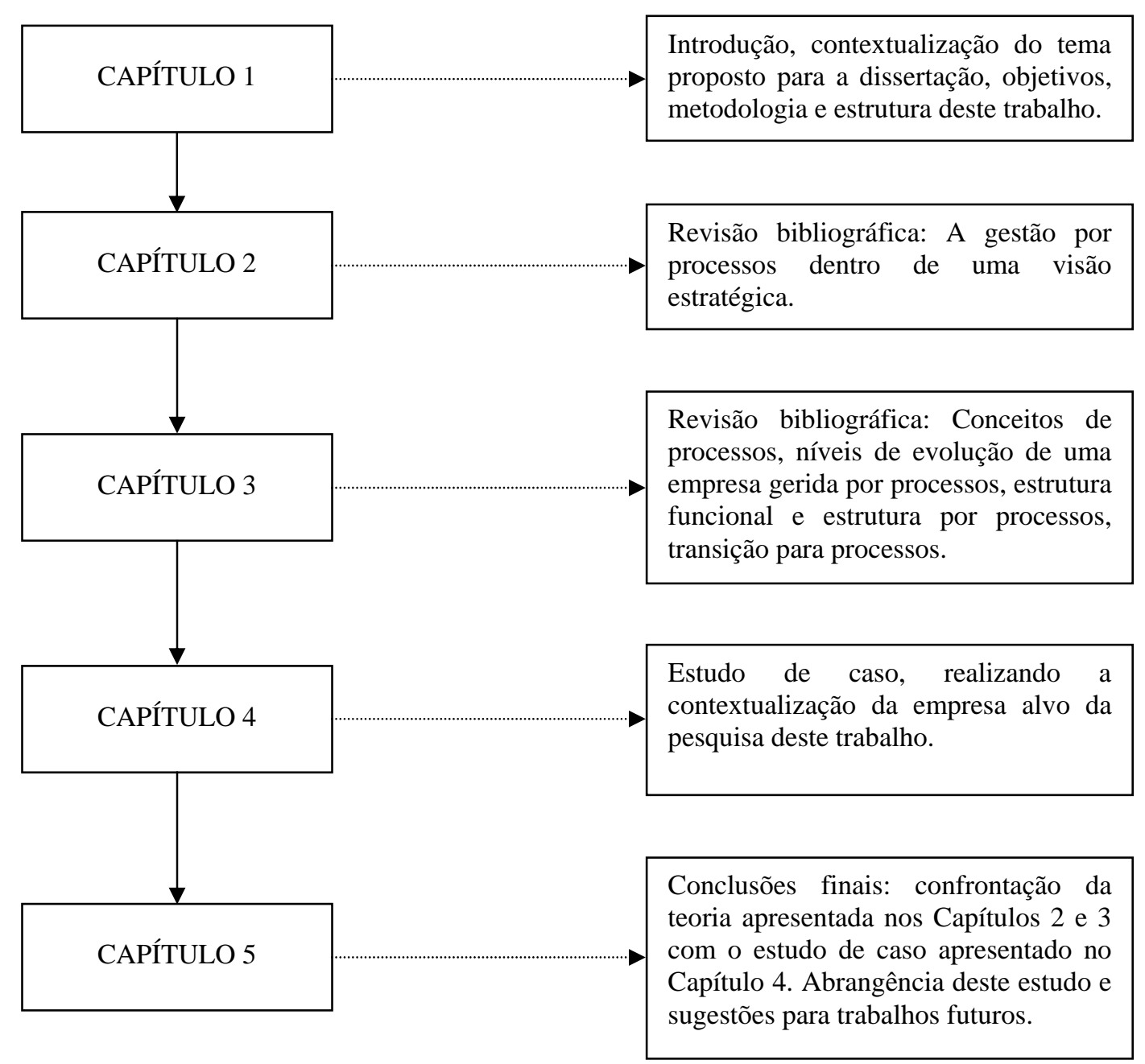

Figura 1 - Estrutura do trabalho 
O segredo do sucesso não é prever o futuro, mas criar uma organização que prosperará em um futuro que não pode ser previsto.

Hammer, 1997

\section{PLANEJAMENTO ESTRATÉGICO, MODELO DE GESTÃo ESTRATÉGICA E PROCESSOS}

Este Capítulo apresenta uma revisão da literatura sobre a importância do planejamento estratégico para uma organização de modo que ela efetivamente possa alcançar seus objetivos e buscar um desenvolvimento competitivo sustentável em um mercado cada vez mais globalizado e dinâmico. Apresenta-se, também, o modelo de gestão estratégica, Balanced Scorecard, desenvolvido por Kaplan e Norton em 1992, que traduz o planejamento estratégico em objetivos e medidas sob quatro perspectivas: financeiras, do cliente, dos processos internos e de aprendizado e crescimento. Finalmente, mostra a necessidade de ligação dos processos com o planejamento estratégico de uma organização para que seus objetivos estratégicos sejam alcançados de forma efetiva.

\subsection{Planejamento Estratégico}

O modelo industrial de Adam Smith (1723-1790) e Henry Ford (1863-1947) foi apropriado para um ambiente onde havia mais demanda que oferta e se fazia necessária a criação de condições para elaboração e aperfeiçoamento da produção em massa. A saturação da demanda por bens de consumo padronizados, resultante da produção em 
massa, por volta de 1930, fez com que o consumidor começasse a exigir mais que desempenho básico. Com essa nova exigência, as empresas passaram, então, a ter uma orientação para o marketing, possibilitando a criação de novas tecnologias e produtos.

Até a década de 1950, a evolução industrial foi “seqüencial”. Constituída por uma sucessão de períodos: de orientação para a empresa, de orientação para produção, de orientação para o marketing. À medida que os períodos se sucediam, a atenção e as prioridades de administração se deslocavam, correspondentemente, de uma preocupação central para outra. Porém, na década de 1970, as prioridades não mais se substituíam, ao contrário, prioridades novas se sobrepunham às anteriores (ANSOFF, 1988).

O antigo ambiente seguro, no qual as empresas operavam, passou a ser um ambiente cada vez mais mutável e complexo, em uma civilização em contínua e acelerada mudança.

Dessa forma, ao longo da história econômica dos últimos cem anos, percebe-se a evolução do centro da administração, que passa da eficiência para a eficácia. Essa eficácia traduzida como o "fazer as coisas certas” com eficiência, ou seja, “da melhor forma possível”.

Aliado a esses dois indicadores (eficiência/eficácia), há ainda um terceiro indicador, não menos importante, talvez até o principal- a efetividade, que avaliará, além “do fazer as coisas certas” e “da melhor forma possível”, se o objetivo proposto foi atingido, ou seja, se os clientes estão satisfeitos com a utilização dos produtos ou serviços resultantes do processo.

Para fazer as coisas certas, ou seja, acertar as ações da empresa em relação às necessidades atuais e futuras, a administração estratégica exerce papel fundamental.

Slack et al. (1999, p.74) definem estratégia como “o padrão global de decisões e ações que posicionam a organização em seu ambiente e têm o objetivo de fazê-la atingir seus objetivos de longo prazo". Essas decisões têm efeito abrangente e, por isso, são significativas na parte da organização à qual se refere à estratégia. 
Para Ansoff, Declerck e Hayes (1990, p.45), “as estratégias são expressões operacionais de políticas, no sentido que, dentro de um sistema de administração, elas definem critérios operacionais sobre os quais os 'programas estratégicos’ são concebidos, relacionados e implantados”.

Mintzberg, Ahlstrand e Lampel (2000) relacionam cinco significados para estratégia. Primeiro, a estratégia é um plano elaborado para direcionar a empresa. A estratégia pode, também, ser entendida como um padrão de comportamento que uma determinada empresa segue ao longo de sua história, direcionando suas ações e decisões importantes. A estratégia pode ser uma posição no mercado, na busca de vantagens competitivas, escolhida por uma empresa para obter melhores condições de negociação. Estratégia é uma perspectiva, segundo uma grande visão da empresa em relação ao que pode ser esperado do futuro e o que será feito a respeito. Estratégia, enfim, pode ser uma manobra para obter uma posição privilegiada, relacionada à manutenção de posição ou busca de poder.

“A essência da estratégia é escolher desempenhar atividades diferentemente do que os concorrentes fazem” (PORTER, 1996, p.64). Para isso as organizações devem ser flexíveis para rapidamente responderem às mudanças competitivas e mercadológicas, devem continuamente fazer benchmarking para alcançar as melhores práticas e concentrarem-se em suas competências essenciais (core competences).

No entanto, Hammer (1997) alerta para a necessidade das empresas de tratarem suas necessidades de mudança tão seriamente quanto trata o trabalho real que executam. "O tipo de mudança que as empresas estão vivenciando atualmente é inesperado e imprevisível. O ritmo de mudança acelerou-se; o horizonte de tempo foi reduzido. No momento em que as empresas conseguem visualizar uma mudança de abordagem, seus efeitos já estão atuando sobre elas. No momento em que a maioria das empresas consegue perceber o que vai acontecer, já aconteceu. [...] O segredo do sucesso não é prever o futuro, mas criar uma organização que prosperará em um futuro que não pode ser previsto.” (HAMMER, 1997, p.189). 
Kaplan e Norton (2004) destacam a importância da estratégia para uma organização, não como um processo isolado, mas uma das etapas de um processo contínuo lógico que movimenta toda a organização desde o alto nível gerencial até o trabalho executado pelos empregados da linha de frente e de suporte.

Para Porter (1996), o planejamento estratégico envolve uma seqüência de atividades vitais para o sucesso de uma organização como um todo e incluem:

- uma avaliação cuidadosa do ambiente em que a organização está inserida;

- uma análise das mudanças nesse ambiente, com uma projeção para o futuro;

- uma avaliação da própria organização em relação à missão, recursos e suas competências administrativas;

- a definição dos objetivos que a empresa gostaria de alcançar a longo prazo;

- uma avaliação das mudanças prováveis no ambiente externo e as oportunidades à mudança para se chegar aos objetivos;

- implementação do plano estratégico;

- medidas de progressos e revisão de planos.

Mintzberg (1998) apresenta como o planejamento estratégico é exercitado em uma organização. Segundo ele, as estratégias podem se formar como podem ser formuladas. Uma estratégia pode emergir como resposta a uma situação em evolução ou pode ser introduzida deliberadamente, por meio de um processo de formulação seguido de implementação. A adoção de uma estratégia formal ou emergente está diretamente relacionada à aprendizagem e controle. Uma estratégia puramente deliberada bloqueia a aprendizagem, uma vez que a estratégia já está formulada, enquanto uma estratégia emergente acaba favorecendo-a. 
De acordo com Silva (2003, p.64), “uma estratégia de fato deliberada tem de ser fruto de um conjunto de pretensões realizadas conforme a idéia original, sem interferências. Da mesma forma, uma estratégia emergente é consistente em suas ações sem qualquer sugestão de intenções, desde que seja atribuído um grau de importância relevante a essas ações”.

Mintzberg, Ahlstrand e Lampel (2000) apresentam dez “escolas de pensamento” para a formulação de estratégia:

a) Escola do Design: formulação de estratégia como um processo de concepção. Busca atingir uma adequação entre as capacidades internas (pontos fortes e pontos fracos) e as possibilidades externas da organização (oportunidades e ameaças);

b) Escola do Planejamento: formulação de estratégia como um processo formal. A estratégia deve ser guiada por um quadro de planejamento altamente formal (procedimento, treinamento e análise formais), por um departamento especializado de planejamento estratégico com acesso direto ao executivo principal;

c) Escola do Posicionamento: formulação de estratégia como um processo analítico. Essa escola focaliza o conteúdo das estratégias, prescrevendo estratégias específicas disponíveis às organizações e os contextos nos quais cada uma funciona melhor. $\mathrm{Na}$ escola do posicionamento, poucas estratégias-chave são desejáveis em uma determinada organização, ao contrário da escola do planejamento e do design, que não impõem limites sobre as estratégias possíveis;

d) Escola Empreendedora: formulação de estratégia como um processo visionário. A partir dessa escola, muda o foco das escolas prescritivas, movendo-se em direção àquelas de descrição, as quais procuram entender o processo de formação de estratégia à medida que esse se desdobra. A escola empreendedora apresenta o processo de formulação de estratégia em uma perspectiva menos coletiva e mais individual, baseada na visão do líder, em sua intuição, julgamento, sabedoria, experiência e critério; 
e) Escola Cognitiva: formulação de estratégia como um processo mental. Essa escola busca entender a mente do estrategista. Nessa escola os pesquisadores preocupam-se com o pensamento em si e não com os requisitos para pensar;

f) Escola de Aprendizado: formulação de estratégia como um processo emergente. De acordo com essa escola, as estratégias emergem quando as pessoas, atuando individual ou coletivamente, aprendem a respeito de uma situação tanto quanto a capacidade da sua organização de lidar com ela, e convergem sobre padrões de comportamento que funcionam. Sugerindo que a imagem tradicional de formulação de estratégia foi uma fantasia, que pode ter sido atraente para certos executivos, mas não correspondeu à realidade das organizações, a escola de aprendizado questiona quem é realmente o arquiteto da estratégia e onde ocorre, de fato, a formação de estratégia nas organizações;

g) Escola do Poder: formulação de estratégia como um processo de negociação. Essa escola caracteriza a formação de estratégia como um processo aberto de influência, enfatizando o uso de poder e política para negociar estratégias favoráveis a determinados interesses;

h) Escola Cultural: formulação de estratégia como um processo coletivo. Contrária a escola do poder que focaliza o interesse próprio, essa escola destaca o interesse comum, estando a formação da estratégia enraizada na força social da cultura da organização;

i) Escola Ambiental: formulação de estratégia como um processo reativo. O ambiente é o ponto principal nessa escola determinando as diretrizes a serem seguidas pela organização;

j) Escola de Configuração: formulação de estratégia como um processo de transformação. Por um lado descreve-se os estados da organização e do contexto que a cerca (configurações) e por outro descreve-se o processo de geração de estratégia (transformação). A geração da estratégia salta de um lado para outro. 
Mintzberg, Ahlstrand e Lampel (2000) dividem as escolas em três grupos e apresentam suas principais características, conforme descritas nos Quadros 1, 2 e 3:

- as três primeiras escolas são de natureza prescritiva - mais preocupadas em como as estratégias devem ser formuladas do que em como elas são formuladas;

- as seis escolas seguintes consideram aspectos específicos do processo de formulação de estratégias preocupando-se mais em descrever como as estratégias são, de fato, formuladas, do que com a prescrição do comportamento estratégico ideal;

- a última escola combina as demais. Busca-se a integração, agrupando-se vários elementos como processo de formulação de estratégias, conteúdo das mesmas, estruturas organizacionais e seus contextos, em estágios distintos.

\section{Quadro 1 - Premissas das escolas prescritivas do pensamento para formulação de estratégia}

\begin{tabular}{|c|c|c|}
\hline \multicolumn{2}{|r|}{ Escolas } & Premissas \\
\hline \multirow{3}{*}{ : } & Design & $\begin{array}{l}\text { - a formação da estratégia deve ser um processo deliberado de pensamento consciente; } \\
\text { - a responsabilidade pelo controle e percepção é do executivo principal; } \\
\text { - o modelo da formação de estratégia deve ser mantido simples e informal; } \\
\text { - as estratégias devem ser únicas: as melhores resultam de um processo de design } \\
\text { individual; } \\
\text { - o processo de design está completo quando as estratégias parecem plenamente } \\
\text { formuladas como perspectiva; } \\
\text { - essas estratégias devem ser explícitas; assim precisam ser mantidas simples; } \\
\text { - depois que essas estratégias únicas, desenvolvidas, explícitas e simples são } \\
\text { totalmente formuladas elas podem ser implementadas. }\end{array}$ \\
\hline & Planejamento & $\begin{array}{l}\text { - as estratégias devem resultar de um processo controlado e consciente de } \\
\text { planejamento formal, decomposto em etapas distintas, cada uma delineada por } \\
\text { checklists e apoiada por técnicas; } \\
\text { - a responsabilidade por todo o processo está, em princípio, com o executivo } \\
\text { principal; na prática, a responsabilidade pela execução está com os planejadores; } \\
\text { - as estratégias surgem prontas desse processo, devendo ser explicitadas para que } \\
\text { possam ser implementadas através da atenção detalhada a objetivos, orçamento, } \\
\text { programas e planos operacionais de vários tipos. }\end{array}$ \\
\hline & Posicionamento & $\begin{array}{l}\text { - estratégias são posições genéricas, especificamente comuns e identificáveis no } \\
\text { mercado; } \\
\text { - o mercado (o contexto) é econômico e competitivo; } \\
\text { - o processo de formação de estratégia é, portanto, de seleção dessas posições } \\
\text { genéricas com base em cálculos analíticos; } \\
\text { - os analistas desempenham um papel importante nesse processo, passando os } \\
\text { resultados dos cálculos aos gerentes que, oficialmente, controlam as opções; } \\
\text { - as estratégias saem desse processo totalmente desenvolvidas para serem } \\
\text { articuladas e implementadas; de fato, a estrutura do mercado dirige-se as } \\
\text { estratégias posicionais deliberadas, as quais dirigem a estrutura organizacional. }\end{array}$ \\
\hline
\end{tabular}

Fonte: Adaptado de Mintzberg, Ahlstrand e Lampel (2000). 


\section{Quadro 2 - Premissas das escolas descritivas do pensamento para formulação de estratégia}

\begin{tabular}{|c|c|c|}
\hline \multicolumn{2}{|r|}{ Escolas } & Premissas \\
\hline \multirow{6}{*}{ 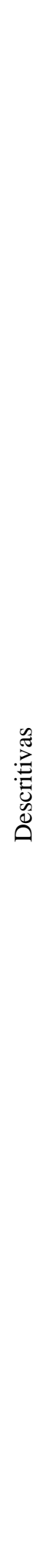 } & Empreendedora & $\begin{array}{l}\text { - a estratégia existe na mente do líder como perspectiva, especificamente um senso de } \\
\text { direção a longo prazo, uma visão do futuro da organização; } \\
\text { - o processo de formação da estratégia é, na melhor das hipóteses, semi-consciente, } \\
\text { enraizado na experiência e na intuição do líder; } \\
\text { - o líder promove a visão de forma decidida, até mesmo obsessiva, mantendo controle } \\
\text { pessoal da implementação; } \\
\text { - a visão estratégica é maleável e, assim, a estratégia empreendedora tende a ser } \\
\text { deliberada e emergente - deliberada na visão global e emergente na maneira pela qual os } \\
\text { detalhes da visão se desdobram; } \\
\text { - a organização é igualmente maleável, uma estrutura simples sensível às diretivas do líder. }\end{array}$ \\
\hline & \begin{tabular}{|l|} 
Cognitiva \\
\end{tabular} & $\begin{array}{l}\text { - a formação de estratégia é um processo cognitivo que tem lugar na mente do estrategista; } \\
\text { - as estratégias emergem como perspectivas - na forma de conceitos, mapas, esquemas e molduras - } \\
\text { que dão forma à medida pela qual as pessoas lidam com informações vindas do ambiente; } \\
\text { - essas informações fluem através de todos os tipos de filtros deturpadores, antes de serem } \\
\text { decodificadas pelos mapas cognitivos, ou são meramente interpretações de um mundo } \\
\text { que existe somente em termos de como é percebido. Em outras palavras, o mundo visto } \\
\text { pode ser modelado, emoldurado e construído. }\end{array}$ \\
\hline & Aprendizado & $\begin{array}{l}\text { - a natureza complexa e imprevisível do ambiente da organização, muitas vezes associada } \\
\text { à difusão de bases de conhecimento necessárias à estratégia, impede o controle } \\
\text { deliberado; a formação de estratégia precisa, acima de tudo, assumir a forma de um } \\
\text { processo de aprendizado ao longo do tempo, no qual, no limite, formulação e } \\
\text { implementação tornam-se indistingüíveis; } \\
\text { - embora o líder também deva aprender, às vezes, pode ser o principal aprendiz, em geral } \\
\text { é o sistema coletivo que aprende: na maior parte das organizações há muitos } \\
\text { estrategistas em potencial; } \\
\text { - esse aprendizado procede de forma emergente, através do comportamento que estimula o } \\
\text { pensamento retrospectivo para que se possa compreender a ação. As iniciativas estratégicas } \\
\text { são tomadas por quem quer que tenha capacidade e recursos para poder aprender; } \\
\text { - o papel da liderança passa a ser de não preconceber estratégias deliberadas, mas de gerenciar } \\
\text { o processo de aprendizado estratégico, pelo qual novas estratégias podem emergir. }\end{array}$ \\
\hline & Poder & $\begin{array}{l}\text { - a formação de estratégia é moldada por poder e política, seja como um processo dentro da } \\
\text { organização ou como o comportamento da própria organização em seu ambiente externo; } \\
\text { - as estratégias que podem resultar desse processo tendem a ser emergentes e assumem } \\
\text { mais a forma de posições e meios de iludir do que de perspectivas; } \\
\text { - o poder micro vê a formação de estratégia como a interação, através de persuasão, } \\
\text { enquanto o poder macro vê a organização como promovendo seu próprio bem-estar por } \\
\text { controle ou cooperação com outras organizações. }\end{array}$ \\
\hline & Cultural & $\begin{array}{l}\text { - a formação de estratégia é um processo de interação social, baseado nas crenças e } \\
\text { interpretações comuns aos membros da organização; } \\
\text { - um indivíduo adquire essas crenças através de um processo de aculturação ou } \\
\text { socialização, o que é em grande parte tácito e não verbal, embora seja, às vezes, } \\
\text { reforçado por uma doutrinação mais formal; } \\
\text { - os membros de uma organização podem descrever apenas parcialmente as crenças que } \\
\text { sustentam sua cultura, ao passo que as origens e explicações podem permanecer obscuras; } \\
\text { - a estratégia assume a forma de uma perspectiva, enraizada em intenções coletivas (não } \\
\text { necessariamente explicadas) e refletida nos padrões pelos quais os recursos ou } \\
\text { capacidades da organização são protegidos e usados para sua vantagem competitiva; } \\
\text { - a estratégia é melhor descrita como deliberada; } \\
\text { - a cultura e, em especial, a ideologia não encoraja tanto as mudanças estratégicas, quanto } \\
\text { a perpetuação da estratégia existente; na melhor das hipóteses, elas tendem a promover } \\
\text { mudanças de posição dentro da perspectiva estratégica global da organização. }\end{array}$ \\
\hline & Ambiental & $\begin{array}{l}\text { - o ambiente, apresentando-se à organização como um conjunto de forças gerais, é o } \\
\text { agente central no processo de geração de estratégia; } \\
\text { - a organização deve responder a essas forças, ou será “eliminada”; } \\
\text { - a liderança torna-se um elemento passivo para fins de ler o ambiente e garantir uma } \\
\text { adaptação adequada pela organização; } \\
\text { - as organizações acabam se agrupando em nichos distintos do tipo ecológico, posições } \\
\text { nas quais permanecem até que os recursos se tornem escassos ou as condições } \\
\text { demasiado hostis. Então elas morrem. }\end{array}$ \\
\hline
\end{tabular}

Fonte: Adaptado de Mintzberg, Ahlstrand e Lampel (2000). 


\section{Quadro 3 - Premissas das escolas da integração do pensamento para formulação de estratégia}

\begin{tabular}{|c|c|c|}
\hline \multicolumn{2}{|c|}{ Escolas } & Premissas \\
\hline 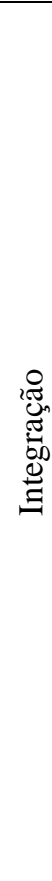 & Configuração & $\begin{array}{l}\text { - na maioria das vezes, uma organização pode ser descrita em termos de algum tipo de } \\
\text { configuração estável de suas características: para um período distinguível de tempo, } \\
\text { ela adota uma determinada forma de estrutura adequada a um determinado tipo de } \\
\text { contexto, o que faz com que ela se engaje em determinados comportamentos que dão } \\
\text { origem a um determinado conjunto de estratégias; } \\
\text { - esses períodos de estabilidade são ocasionalmente interrompidos por algum } \\
\text { processo de transformação - um salto quântico para outra configuração; } \\
\text { - esses estados sucessivos de configuração e períodos de transformação podem se } \\
\text { ordenar ao longo do tempo em sequiências padronizadas, por exemplo, descrevendo } \\
\text { ciclos de vida de organizações; } \\
\text { - a chave para a administração estratégica é sustentar a estabilidade ou, no mínimo, } \\
\text { mudanças estratégicas adaptáveis a maior parte do tempo, mas reconhecer } \\
\text { periodicamente a necessidade de transformação e ser capaz de gerenciar esse } \\
\text { processo de ruptura sem destruir a organização; } \\
\text { - o processo de geração de estratégia pode ser de concepção conceitual ou } \\
\text { planejamento formal, análise sistemática ou visão estratégica, aprendizado } \\
\text { cooperativo ou politicagem competitiva, focalizando cogniçãa individual, } \\
\text { socialização coletiva ou a simples resposta às forças do ambiente; mas cada um } \\
\text { deve ser encontrado em seu próprio tempo e contexto; } \\
\text { - as estratégias resultantes assumem a forma de planos ou padrões, posições ou } \\
\text { perspectivas ou meios de iludir; porém, mais uma vez, cada um ao seu tempo e } \\
\text { adequado à sua situação. }\end{array}$ \\
\hline
\end{tabular}

Fonte: Adaptado de Mintzberg, Ahlstrand e Lampel (2000).

"Sem uma descrição abrangente da estratégia, os executivos não podem divulgar com facilidade a estratégia entre si e compartilhá-la com os funcionários. Sem o entendimento comum da estratégia, os executivos são incapazes de promover o alinhamento em torno dela. E, sem alinhamento, os executivos não têm condições de implementar suas novas estratégias no novo ambiente de competição global, desregulamentação, soberania dos clientes, avanços tecnológicos e vantagem competitiva originada pelos ativos intangíveis, principalmente capital humano e da informação” (KAPLAN e NORTON, 2004, p.6).

\subsection{Modelo de gestão estratégica: Balanced Scorecard}

Para Ansoff, Declerck e Hayes (1990, p.58), “a resultante do planejamento estratégico é apenas um conjunto de planos e intenções. Por si mesmo, o 
planejamento estratégico não produz ações, nem mudanças visíveis na empresa. Para efetuar as mudanças a empresa necessita de aptidões adequadas: administradores treinados e motivados, informação estratégica, sistemas e estruturas fluídas e com tendência a serem compreensivos".

São necessários instrumentos gerenciais para traduzir essa estratégia em medidas operacionais.

Diante dessa necessidade, em 1992, Kaplan e Norton desenvolveram o Balanced Scorecard, como um instrumento necessário para se alcançar o sucesso.

Segundo Kaplan e Norton (1997), o Balanced Scorecard viabiliza processos gerenciais críticos:

- esclarece e traduz a visão e a estratégia;

- comunica e associa objetivos e medidas estratégicas;

- planeja, estabelece metas e alinha iniciativas estratégicas;

- melhora o feedback e o aprendizado estratégico.

O Balanced Scorecard "traduz a missão e a estratégia das empresas em um conjunto abrangente de medidas de desempenho que serve de base para um sistema de medição e gestão estratégica” (KAPLAN e NORTON, 1997, p.2). Esse desempenho organizacional é medido sobre quatro perspectivas equilibradas: financeira, do cliente, dos processos internos e do aprendizado e crescimento, que formam a estrutura do Balanced Scorecard (Figura 2).

Nesta dissertação utiliza-se o termo aprendizado com o sentido de processo de aprendizagem e não com o sentido de resultado desse processo pelo fato de se ter constatado a predominância desse uso na revisão de literatura. 


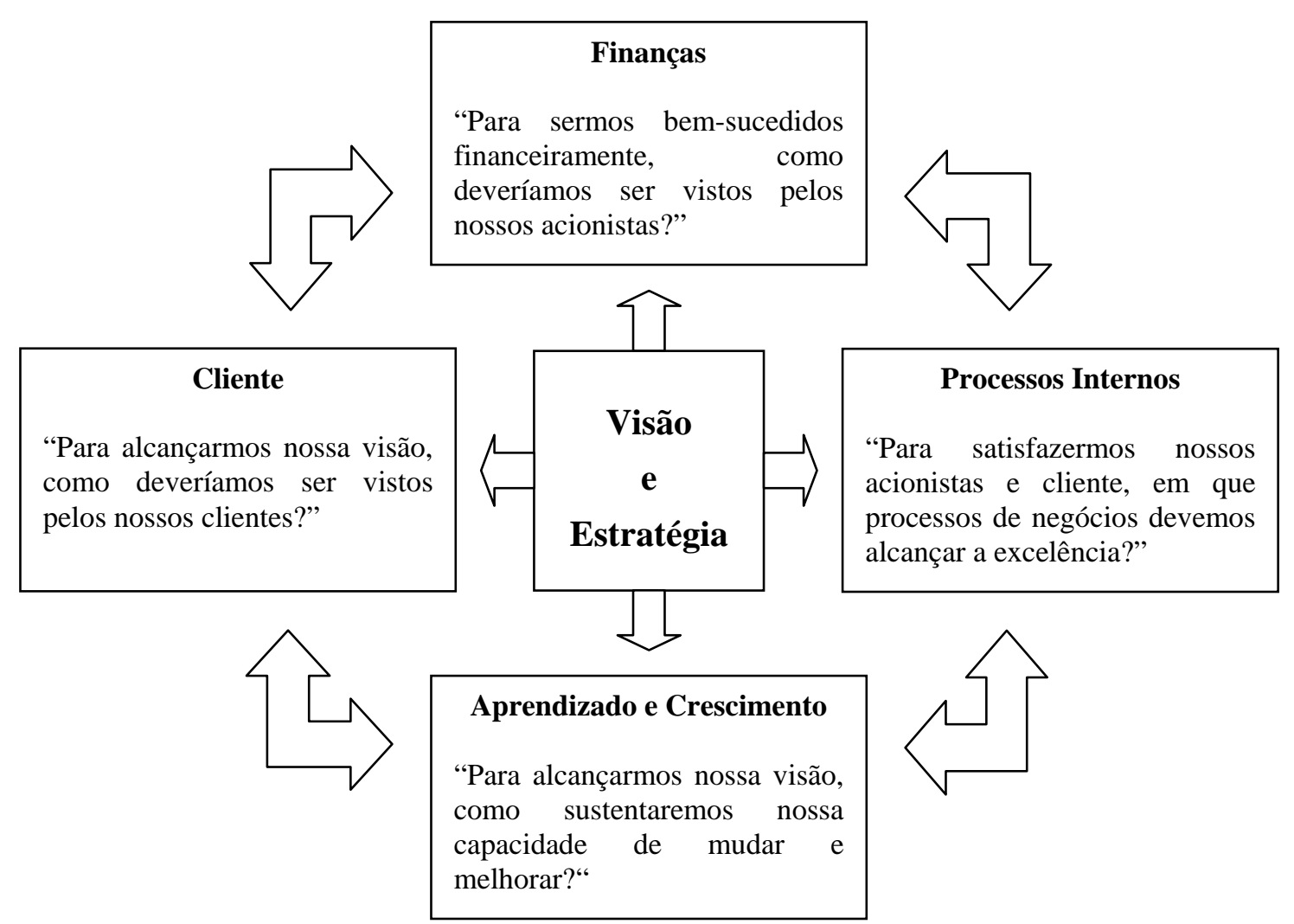

Fonte: Kaplan e Norton (1997).

Figura 2 - Estrutura do Balanced Scorecard

Os sistemas tradicionais de medição de desempenho, mesmo aqueles que utilizam indicadores não-financeiros, costumam se concentrar na melhoria dos custos, qualidade e ciclos dos processos existentes. O Balanced Scorecard destaca os processos mais críticos para a obtenção de um desempenho superior para clientes e acionistas. Em geral, essa identificação revela processos internos totalmente novos nos quais a organização deve buscar a excelência para que sua estratégia seja bem sucedida (KAPLAN e NORTON, 1997, p.11).

Almeida (2002) relata que, dentre as perspectivas apresentadas pelo Balanced Scorecard, processos internos destaca-se pela maior quantidade de indicadores utilizados pela maioria de empresas bem sucedidas. Esse destaque é facilmente explicável pelo fato de nos processos internos estarem as atividades que transformarão os insumos em produtos/serviços que os clientes querem adquirir. 
Por fim, as metas de aprendizado e crescimento produzem inovações e melhorias importantes para os processos internos de negócios, para os clientes e acionistas, uma vez que mostram os motivos para investimentos em reciclagem de funcionários, tecnologias e sistemas de informação e na melhoria dos procedimentos organizacionais.

Embora focado em medições de desempenho, Kaplan e Norton (1997) enfatizam que o Balanced Scorecard deve ser utilizado como um sistema de comunicação, informação e aprendizagem, não como um sistema de controle.

Para o setor público e as organizações sem fins lucrativos, o balanced scorecard é semelhante ao setor privado, mas com várias diferenças importantes (KAPLAN e NORTON, 2004). A principal diferença, considerada critério definitivo de sucesso para as organizações do setor público e para as entidades sem fins lucrativos, é o desempenho no cumprimento da missão. Essas organizações abrangem um conjunto amplo e diversificado de missões e, portanto, devem definir seu impacto social e seus objetivos maiores de maneira diferente.

Nesse modelo para organizações públicas e sem fins lucrativos, verificase a existência de medidas não-financeiras, destacadas por Silva (2003), como importantes para os modelos de gestão. Para ele, o modelo contábil foi desenvolvido em um ambiente completamente diferente do de hoje, regido unicamente por controles de estoques e processos de produção a custos baixos, não fundamentados em geração de valor agregado para o cliente por meio de qualidade e relacionamentos mantidos entre esse e a organização, nem na capacidade de inovação e lançamento de novos produtos.

Segundo Kaplan e Norton (1997), as medidas financeiras não são mais suficientes para orientar uma organização. Elas contam parte, mas não toda a história das ações passadas e não fornecem orientações adequadas para as ações que devem ser realizadas hoje e amanhã para criar valor financeiro. No entanto elas não devem ser desprezadas.

Campos (1998) também destaca essa mudança de enfoque por parte das organizações, as quais estão criando sistemas de gestão baseados não somente em medidas financeiras mas também na satisfação e retenção do cliente, melhoria e inovação dos produtos e processos internos, aprendizado contínuo e crescimento de seus 
colaboradores e parceiros. Os sistemas de medição financeira produziram bons resultados, mas hoje se mostram insuficientes para ajudar as empresas que necessitam evoluir e dominar novas habilidades e competências.

Campos (1998) alerta, ainda, para o perigo de uma organização se orientar essencialmente para as variáveis financeiras, pois os sistemas de medição do desempenho tendem a motivar os gerentes a concentrarem esforços quase exclusivamente no lucro a curto prazo e na redução de custos, ignorando muitas vezes fatores críticos que determinam o sucesso a longo prazo dos negócios.

No entanto, Kaplan e Norton (1997) diferenciam o Balanced Scorecard dos demais sistemas gerenciais não somente pela existência de medidas não-financeiras, pois muitas organizações já trabalham com essas medidas, relacionadas a programas de qualidade e satisfação de clientes, mas também pelo fato de que "os objetivos e medidas do scorecard derivam da visão e da estratégia da empresa”.

O processo de criação do Balanced Scorecard inicia-se com um trabalho da alta administração em traduzir a estratégia em objetivos estratégicos específicos. As medidas financeiras são estabelecidas priorizando-se a receita e o crescimento de mercado, tendo-se claro qual o segmento de clientes e mercados a serem atingidos. Uma vez estabelecidas as metas financeiras e de clientes, a organização concentra-se nos objetivos e medidas para seus processos internos. Essa etapa constitui uma das principais inovações e benefícios dessa abordagem.

\subsubsection{As quatro perspectivas do Balanced Scorecard}

\subsubsection{Perspectiva financeira}

As medidas financeiras não devem ser descartadas pela organização dentro das perspectivas apresentadas para o desempenho empresarial, uma vez que são valiosas para sintetizar as conseqüências econômicas imediatas de ações consumadas. 
Segundo Kaplan e Norton (1997, p.49), “os objetivos financeiros servem de foco para os objetivos e medidas das outras perspectivas do scorecard".

Muitas empresas adotam os mesmos objetivos financeiros para suas unidades de negócios, tornando-se uma atitude inadequada, uma vez que essa uniformidade não leva em consideração o fato de as unidades de negócio poderem estar seguindo estratégias bem diferentes.

Kaplan e Norton (1997) identificam três fases do ciclo de vida de uma empresa, nas quais os objetivos financeiros devem estar vinculados, de acordo com a estratégia que melhor se enquadre para cada fase. São elas, crescimento, sustentação e colheita.

O ciclo de vida tem início com a fase de crescimento, na qual são necessários elevados níveis de investimento para criar a infra-estrutura, implantar os processos internos necessários ao funcionamento da empresa e rapidamente ampliar a fatia de mercado. A fase de sustentação caracteriza-se pela busca da lucratividade e retorno do capital investido, melhoria dos processos internos; é a fase na qual se encontra a maior parte das empresas e unidades de negócio. Quando a empresa atinge maturidade, passa para a última fase do ciclo, na qual a meta principal é a maximização do fluxo de caixa operacional em benefício da empresa e diminuição da necessidade de capital de giro. Cabe aos gerentes identificar em que fase se encontra sua empresa ou unidade de negócios, para estabelecer os objetivos e indicadores financeiros adequados, levando em conta os temas estratégicos da empresa.

\subsubsection{Perspectiva do cliente}

O propósito da perspectiva de clientes no Balanced Scorecard é identificar os melhores segmentos de clientes e mercados nos quais a unidade de negócio deseja competir e criar medidas de desempenho que serão utilizadas, uma vez 
que os clientes atuais e potenciais não são homogêneos, com preferências diversas e valorizando atributos dos produtos ou serviços de formas diferentes.

Kaplan e Norton (2004) destacam que, apenas satisfazer e reter clientes não chega a ser estratégia. Para se configurar uma estratégia, a empresa precisa identificar segmentos de clientes específicos para promover o crescimento e a rentabilidade e, a partir disso, identificar os objetivos e os indicadores de sua proposição de valor para com seus clientes.

Essa proposta de valor refere-se a um conjunto de atributos dos produtos e serviços da organização capazes de atrair o interesse dos clientes e resultar em bons indicadores nas medidas acima mencionadas. A proposta de valor pode contemplar três categorias:

- proposta de valor nos atributos dos produtos ou serviços: refere-se à funcionalidade (utilidade ou efetividade), qualidade e preço dos produtos ou serviços da organização para o cliente;

- proposta de valor no relacionamento com clientes: refere-se à capacidade da organização de perceber as necessidades dos clientes e agir de acordo com essas percepções;

- proposta de valor na imagem e na reputação: refere-se à capacidade da organização de comunicar-se com o público da organização (clientes ou não) e persuadi-lo quanto às vantagens de realizar negócios com ela.

Kaplan e Norton (1997) apresentam um grupo de medidas essenciais de clientes comuns a todos os tipos de empresas, podendo ser agrupados em uma cadeia na forma de relações de causa e efeito (Figura 3). São elas: participação de mercado, retenção, captação, satisfação e lucratividade de clientes. 


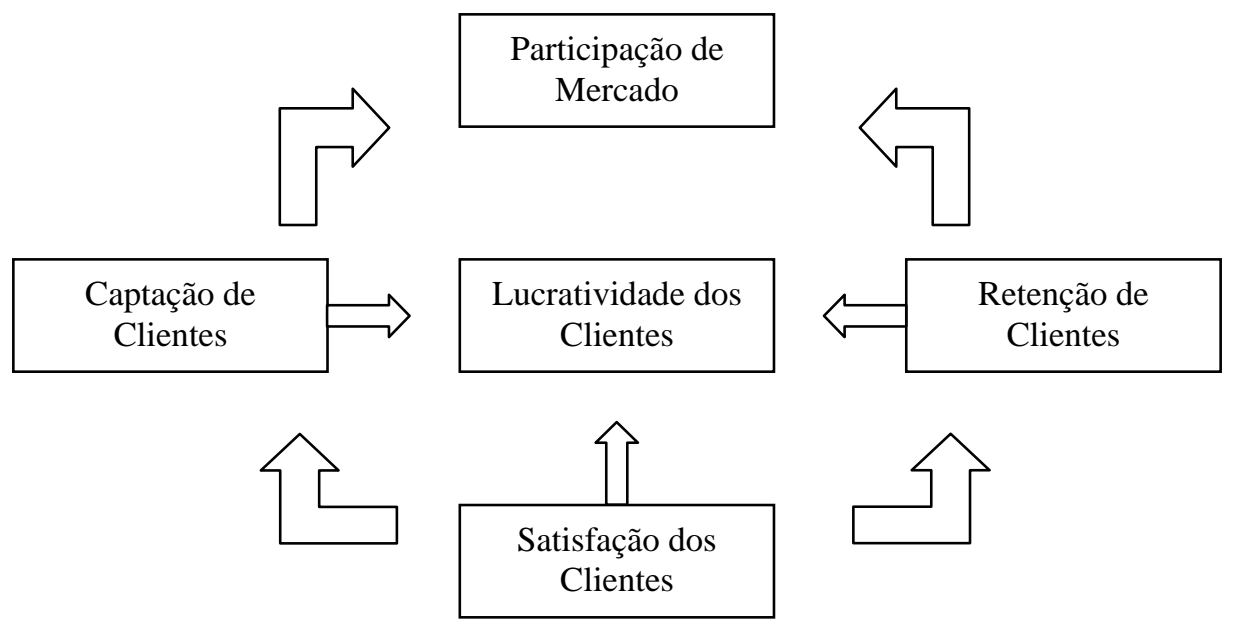

Fonte: Kaplan e Norton (1997).

Figura 3 - A perspectiva do cliente - medidas essenciais

\subsubsection{Perspectiva dos processos internos}

$\mathrm{Na}$ perspectiva de processos internos as organizações buscam identificar quais os processos mais críticos para a realização dos objetivos dos clientes e acionistas. Normalmente, os objetivos e medidas de desempenho para essa perspectiva são desenvolvidos após a formulação das perspectivas financeira e do cliente e descrevem como executar a estratégia de modo a cumprir a proposição de valor diferenciada da empresa.

Segundo Kaplan e Norton (2004), os processos internos cumprem dois componentes vitais da estratégia da organização:

- produzem e fornecem a proposição de valor para os clientes;

- melhoram os processos e reduzem os custos para dimensão produtividade da perspectiva financeira. 
Kaplan e Norton (2004) dividem os processos internos de uma organização em quatro agrupamentos: processos de gestão operacional, processos de gestão de clientes, processos de inovação, processos regulatórios e sociais.

Os processos de gestão operacional são processos básicos por meio dos quais as empresas produzem e entregam bens e serviços para os clientes. A gestão operacional abrange quatro importantes processos:

a) Desenvolver e sustentar relacionamentos com os fornecedores: essas redes de relacionamento com fornecedores proporcionam vantagens competitivas as empresas, proporcionando redução de custos de aquisição, rapidez de fornecimento, alta capacidade de fornecimento de alta qualidade, criação de parcerias, de modo a criar condições para que a empresa concentre seus recursos e tempo gerencial em processos que fornecem diferenciação;

b) Produzir produtos e serviços: processos operacionais, propriamente ditos, que produzem bens e serviços utilizados pelo cliente da organização, e tem por objetivos reduzir os custos de produção, melhoria contínua dos processos, melhorar a responsividade dos processos, melhorar a utilização do ativo fixo e melhorar a eficiência do capital de giro;

c) Distribuir e entregar produtos e serviços aos clientes: processos referentes à entrega dos produtos e serviços aos clientes. Seus principais objetivos são reduzir custos de servir, entregar com responsividade aos clientes e aumentar a qualidade de entrega;

d) Gerenciar riscos: processos encontrados principalmente em empresas de serviços financeiros e tem como principais objetivos reduzir riscos decorrentes de operações de crédito, movimentos das taxas de juros e flutuações das taxas de câmbio. 
Os processos de gestão de clientes têm importância fundamental na estratégia de negócios de uma empresa. Atualmente, são os clientes quem tomam as iniciativas de compra devendo, as organizações, estarem preparadas e, principalmente, terem um relacionamento com clientes que lhes permitam orientar seus produtos na direção da satisfação das necessidades desses clientes. Os processos de gestão de clientes devem ajudar a empresa a conquistar, sustentar e cultivar relacionamentos rentáveis e duradouros com os clientes-alvo. A gestão de clientes consiste em quatro processos genéricos:

a) Selecionar clientes: o processo de seleção dos clientes inicia-se com a identificação de segmentos de clientes atraentes para empresa. A partir dessa identificação, são elaboradas proposições de valor específicas para esses segmentos e criada uma imagem de marca que atraia os clientes desses segmentos para os produtos e serviços da empresa;

b) Conquistar clientes: uma vez selecionado o cliente, a empresa deve comunicar suas proposições de valores aos novos clientes, na busca de atrair clientes potenciais e convertê-los em clientes efetivos;

c) Reter clientes: o próximo passo é reter esses clientes com produtos e serviços de qualidade, buscando sua fidelidade e, principalmente, o comprometimento desses clientes para com a organização;

d) Cultivar relacionamentos com os clientes: finalmente, aumentar o valor dos clientes da empresa, oferecendo parcerias e desenvolvendo soluções específicas para os clientes-alvo.

Os processos de inovação contínua de produtos, serviços e processos de uma empresa farão com que ela consiga uma posição de destaque no mercado criando vantagem competitiva sustentável. Quatro processos estão inclusos na gestão da inovação: 
a) Identificar oportunidades de novos produtos e serviços: as empresas devem antecipar-se às futuras necessidades dos clientes e descobrir novas oportunidades. Para isso as empresas devem buscar novas idéias tanto internamente, em seus laboratórios de pesquisa, mas também em laboratórios de pesquisas externas, como universidades, e principalmente com fornecedores e clientes criando-se parceiras estratégicas na busca de novas idéias e recursos a respeitos de novos produtos;

b) Gerenciar o portfólio de pesquisa e desenvolvimento: uma vez geradas as idéias, os gestores devem avaliar e decidir quais projetos financiar, adiar ou eliminar. Como resultado dessa avaliação é gerado um plano mestre de projetos de define o portfólio de projetos da empresa;

c) Projetar e desenvolver novos produtos e serviços: é a essência da inovação, que trará novos conceitos ao mercado, tendo como resultados o produto ou serviço com a funcionalidade almejada, atraente para o mercado-alvo e capaz de ser produzido com qualidade consistente e custos que proporcione margem de lucro satisfatória;

d) Lançar novos produtos e serviços no mercado: nesse processo, inicia-se a produção comercial com a construção de protótipos de equipamentos, são verificados os processos de fabricação e a área de marketing e vendas começa a vender o novo produto aos clientes.

Nos processos regulatórios e sociais, as empresas devem observar, em seu país e comunidades, as legislações sobre meio ambiente, segurança e saúde e práticas trabalhistas, e incluírem em suas normas de operações, de modo a evitar paralisações ou litígios dispendiosos à empresa. As empresas gerenciam seus processos regulatórios e sociais baseadas em quatro dimensões:

a) Meio ambiente: vários componentes fazem parte dessa dimensão como consumo de energia e outros recursos; efluentes líquidos (água potável); efluentes gasosos (poluição); produção e descarte de resíduos sólidos; desempenho do produto; indicadores ambientais agregados; 
b) Segurança e saúde: esses indicadores são mais padronizados, baseando-se principalmente nas ocorrências de acidentes de trabalho, exposição dos empregados a riscos;

c) Práticas trabalhistas: boa parte dos relatórios sobre práticas trabalhistas trata do aumento da diversidade de empregados, por exemplo, empregados oriundos de comunidades carentes, percentual de mulheres e negros em cargos executivos;

d) Investimento na comunidade: contribuições financeiras a organizações sem fins lucrativos, trabalho voluntariado dos empregados da empresa na comunidade são exemplos dessa dimensão.

A integração entre esses processos de negócio multifuncionais, com medidas de desempenho mais abrangentes, representa uma melhoria significativa em relação aos sistemas de medição de desempenho existentes.

Essas tendências de avaliação de desempenho reforçam a importância de se medir o desempenho dos processos de negócio, como atendimento a pedidos, compras, planejamento e controle da produção que atravessam vários departamentos organizacionais.

Todas as empresas tentam melhorar a qualidade, reduzir os tempos de ciclo, aumentar a produção, maximizar a produtividade e reduzir os custos de seus processos de negócios. Portanto, a concentração exclusiva em ganhos no tempo de ciclo, produtividade, qualidade e custos dos processos existentes talvez não leve a competências exclusivas. A menos que se possa superar o desempenho dos concorrentes em todos os processos de negócio, qualidade, tempo, produtividade e custo, tais melhorias aumentarão as chances de sobrevivência, mas não gerarão vantagens competitivas distintas e sustentáveis (KAPLAN e NORTON, 1997, p.99). 


\section{Quadro 4 - Principais objetivos dos processos relacionados às perspectivas do balanced scorecard}

\begin{tabular}{|c|c|c|c|}
\hline $\begin{array}{l}\text { Perspectivas } \\
\text { Processos }\end{array}$ & Financeira & Clientes & Aprendizado e Crescimento \\
\hline $\begin{array}{l}\text { Gestão de } \\
\text { operações }\end{array}$ & $\begin{array}{lll}\text { - } \text { Tornar-se líder em custo do } \\
\text { setor; } \\
\text { - Maximizar o uso dos ativos } \\
\text { existentes; } \\
\text { - Aumentar participação nas } \\
\text { compras } & \text { dos } & \text { clientes } \\
\text { existentes; } & & \\
\text { - Aumentar } & \text { a } & \text { receita } \\
\text { decorrente } & \text { de } & \text { novos } \\
\text { clientes. } & & \\
\end{array}$ & $\begin{array}{l}\text { - Reduzir os custos dos } \\
\text { clientes; aumentar o lucro } \\
\text { dos clientes; } \\
\text { - Entregar aos clientes } \\
\text { produtos e serviços zero } \\
\text { defeitos; } \\
\text { - Entregas pontuais; } \\
\text { - Oferta de r portfólio } \\
\text { excelente. }\end{array}$ & $\begin{array}{l}\text { - Desenvolver habilidades } \\
\text { em gestão da qualidade e } \\
\text { em melhoria de processos; } \\
\text { - Adotar tecnologias que } \\
\text { promovam melhoria dos } \\
\text { processos e satisfação dos } \\
\text { clientes; } \\
\text { - Infundir cultura de } \\
\text { melhoria contínua. }\end{array}$ \\
\hline $\begin{array}{l}\text { Gestão de } \\
\text { clientes }\end{array}$ & $\begin{array}{l}\text { - Criar novas fontes de } \\
\text { receita; } \\
\text { - Aumentar a receita por } \\
\text { cliente; } \\
\text { - Elevar rentabilidade dos } \\
\text { clientes; } \\
\text { - Melhorar produtividade das } \\
\text { vendas. }\end{array}$ & $\begin{array}{l}\text { - Aumentar a satisfação dos } \\
\text { clientes por meio de uma } \\
\text { proposição de valor } \\
\text { atraente; } \\
\text { - Intensificar } \\
\text { clientes; } \\
\text { - Criar fãs ardorososodade dos }\end{array}$ & $\begin{array}{l}\text { - Desenvolver competências } \\
\text { estratégicas; } \\
\text { - Atrair e reter talentos de } \\
\text { alto nível; } \\
\text { - Desenvolver portfólio de } \\
\text { dados e informações sobre } \\
\text { gestão de clientes; } \\
\text { - Intensificar } \\
\text { compartilhamento } \\
\text { conhecimentos; } \\
\text { - Desenvolver cultura de } \\
\text { orientação ao cliente; } \\
\text { - Promover alinhamento com } \\
\text { objetivos pessoais. } \\
\end{array}$ \\
\hline Inovação & $\begin{array}{l}\text { - Retorno sobre } \\
\text { investimentos em P\&D; } \\
\text { - Aumento da receita oriunda } \\
\text { dos atuais clientes; } \\
\text { - Aumento da receita oriunda } \\
\text { de novos clientes; } \\
\text { - Gerenciamento dos custos } \\
\text { do ciclo de vida. }\end{array}$ & \begin{tabular}{|lllr|} 
- Oferecer & \multicolumn{2}{c}{ aos } & \multicolumn{2}{c}{ clientes } \\
produtos e & serviços & mais \\
funcionais; & & \\
- Ser o primeiro no mercado \\
com novos & produtos & e \\
serviços; & & & \\
• Estender & produtos & e \\
serviços & a & novos \\
segmentos. & &
\end{tabular} & $\begin{array}{l}\text { - Alcançar profunda } \\
\text { expertise funcional; } \\
\text { - Desenvolver equipes } \\
\text { interdisciplinares e } \\
\text { multifuncionais eficazes; } \\
\text { - Aplicar tecnologia } \\
\text { computacional para } \\
\text { simulação e prototipagem } \\
\text { virtual; } \\
\text { - Usar tecnologia para o } \\
\text { rápido lançamento de } \\
\text { produtos; } \\
\text { - Captar conhecimentos de } \\
\text { ponta da comunidade } \\
\text { científica e tecnológica; } \\
\text { - Fomentar cultura de } \\
\text { inovação. } \\
\end{array}$ \\
\hline $\begin{array}{l}\text { Regulatórios } \\
\text { e sociais }\end{array}$ & \begin{tabular}{|l} 
- Reduzir riscos associados \\
ao negócio; \\
- Atrair clientes \\
$\begin{array}{ll}\text { investidores imbuídos de } \\
\text { consciência ambiental. }\end{array}$ \\
\end{tabular} & $\begin{array}{l}\text { - Propor valor ao cliente em } \\
\text { termos de parcerias na } \\
\text { comunidade; } \\
\text { - Empresa cidadã. }\end{array}$ & $\begin{array}{l}\text { - Investir no crescimento do } \\
\text { capital humano; } \\
\text { - Tecnologias limpas; } \\
\text { - Cultura de consciência e } \\
\text { responsabilidade social. }\end{array}$ \\
\hline
\end{tabular}

Fonte: Adaptado de Kaplan e Norton (2004). 


\subsubsection{Perspectiva do aprendizado e crescimento}

As três perspectivas anteriores - financeira, do cliente e dos processos internos - mostram onde a empresa deve se destacar para obter o desempenho efetivo na busca da competitividade sustentável. A perspectiva do aprendizado e crescimento apresenta a infra-estrutura para a consecução dos objetivos propostos nas perspectivas anteriores, enfatizando a importância de alinhar os ativos intangíveis com a estratégia da organização (Kaplan e Norton, 2004).

Do ponto de vista financeiro, investimentos em infra-estrutura como a capacidade de pessoas, sistemas e processos organizacionais, são difíceis de serem sustentados pelas empresas, uma vez que são considerados despesas do exercício pelo modelo contábil financeiro e a simples redução de investimento produz ganhos incrementais a curto prazo.

O Balanced Scorecard enfatiza a importância de investir no futuro e não apenas em áreas tradicionais de investimento como novos equipamentos e pesquisas e desenvolvimento de novos produtos.

Kaplan e Norton (2004) propõem três componentes principais dos ativos intangíveis para implementação da estratégia, os quais devem estar alinhados com os objetivos dos processos internos e integrados uns aos outros:

- Capital humano: habilidades, conhecimento, valores;

- Capital da informação: sistemas; banco de dados, redes;

- Capital organizacional: cultura, liderança, alinhamento, trabalho em equipe. 
Quanto ao capital humano, durante muito tempo os trabalhadores eram contratados para trabalhos braçais, cabendo à elite organizacional - engenheiros e gerentes - o papel de definir as rotinas e tarefas de cada trabalhador, criando padrões e sistemas para monitorar e garantir a conformidade das tarefas. Atualmente, as empresas começaram a investir em treinamento de seus funcionários para conseguir diferencial competitivo.

As idéias que permitem melhorar os processos e o desempenho para os clientes
cada vez mais emanam dos funcionários da linha de frente, que se encontram
mais próximos dos processos internos e dos clientes da organização. Padrões que
determinavam como os processos internos e a resposta aos clientes deveriam ser
realizados servem como base a partir da qual devem ser feitas melhorias
contínuas, mas não servem como padrões para o desempenho atual e futuro. Essa
mudança exige grande reciclagem dos funcionários, para que suas mentes e
capacidades criativas sejam mobilizadas no sentido dos objetivos
organizacionais (KAPLAN e NORTON, 1997, p.133).

Kaplan e Norton (2004) apresentam um modelo que capacita as organizações a identificar as necessidades de capital humano para a execução de sua estratégia:

a) Identificar funções estratégicas: compete à gestão estratégica identificar e focalizar as poucas funções críticas que exercem maior impacto sobre a estratégia;

b) Definir o perfil de competências: uma vez identificadas as principais funções estratégicas, o próximo passo é definir as especificações dessa função, ou seja, o perfil de competência (conhecimento, habilidades e valores) que o empregado necessita para ser bem sucedido nessa função;

c) Avaliar a prontidão do capital humano: o próximo passo é verificar as atuais capacidades e competências dos empregados em funções estratégicas existentes na organização para suprir as competências necessárias, detectadas no passo anterior; 
d) Instituir programa de desenvolvimento do capital humano: os programas de recursos humanos da organização (recrutamento, treinamento e planejamento de carreiras) devem ser orientados pelo mapa estratégico para atender, principalmente, cargos que realmente tenham funções estratégicas para a organização.

Kaplan e Norton (1997) associam três medidas essenciais para avaliar os funcionários:

- satisfação dos funcionários, mede o nível de satisfação dos funcionários para com a organização;

- retenção dos funcionários, objetiva reter aqueles funcionários nos quais a empresa tem interesse a longo prazo;

- produtividade dos funcionários, mede o resultado do impacto agregado na elevação do nível de habilidade e do moral dos funcionários pela inovação, pela melhoria dos processos internos e pelos clientes satisfeitos.

Quanto ao capital da informação, as informações sobre os clientes, os processos internos e as conseqüências financeiras advindas de atividades desenvolvidas, são necessárias para que os funcionários tenham um desempenho eficaz. Bons serviços de informação são uma exigência para que os funcionários melhorem os processos. Os funcionários da linha de frente necessitam de informações precisas sobre o relacionamento de cada cliente com a organização, para que possam julgar o grau de esforço a ser despendido, não apenas para satisfazer o cliente naquele momento, mas também para conhecer e tentar satisfazer as necessidades emergentes desse cliente. $\mathrm{O}$ capital da informação, composto pelos sistemas, banco de dados, bibliotecas e redes fornece informações e conhecimentos à organização.

Para Kaplan e Norton (2004), o capital da informação deve ser gerenciado para alinhar-se a estratégia e compreende três componentes: 
a) Descrever o capital da informação: a descrição do capital da informação abrange a infra-estrutura de tecnologia e aplicações de capital da informação. A infra-estrutura de tecnologia envolve, além das tecnologias propriamente ditas, as gestões necessárias para o fornecimento e uso eficaz das aplicações de capital de informação. As aplicações de capital de informação dividem-se em três categorias: sistemas transacionais, que automatizam as transações repetitivas básicas da empresas; aplicações analíticas, que promovem a análise, a interpretação e o compartilhamento de informações e conhecimento; e as aplicações transformacionais, que mudam o modelo de negócios predominante da empresa;

b) Alinhar o capital da informação à estratégica: os executivos devem garantir que seu capital de informação esteja alinhado aos processos internos estratégicos da organização, efetuando os devidos investimentos em tecnologia da informação, necessários para garantir esse alinhamento à estratégia da organização;

c) Medir a prontidão do capital da informação: esse componente mede a extensão em que o capital da informação respalda a estratégia da empresa, mostrando o quanto de tecnologia a empresa dispõe e quanto é necessário para atingir determinada estratégia.

Quanto ao capital organizacional. O capital humano e o capital da informação, por si sós não contribuem para o sucesso das organizações. Não basta os funcionários terem acesso total às informações se eles não estiverem motivados para agir em prol do interesse da empresa, ou se não tiverem liberdade para decidir ou agir.

Kaplan e Norton (2004, p.281) definem capital organizacional como "a capacidade da organização de mobilizar e sustentar o processo de mudança necessário para executar a estratégia”.

Esses autores referem, ainda, que esse processo de mudança enquadra-se em duas categorias. A primeira diz respeito às mudanças comportamentais necessárias à 
criação de valor para os clientes, concentrando o foco no cliente, sendo criativos e inovadores e produzindo resultados. A segunda mudança comportamental é necessária para a execução da estratégia, sendo necessário compreender a missão, a estratégia e os valores, promover o senso de responsabilidade, comunicar-se com abertura e trabalhar como equipe.

Nas empresas, o capital organizacional quase sempre é constituído por quatro componentes:

a) Cultura: atitudes e comportamentos predominantes que caracterizam o funcionamento de um grupo ou organização. Consciência e internalização da missão, visão e valores essenciais necessários para executar a estratégia;

b) Liderança: capacidade dos líderes, em todos os níveis, de mobilizarem toda a força de trabalho da organização em direção a uma mudança bem sucedida para a execução da estratégia. O papel da liderança pode ser definido por duas abordagens: um processo para desenvolver líderes e um modelo de competências de liderança;

c) Alinhamento: uma organização alinhada estimula o empowerment (RODRIGUES e SANTOS, 2001) dos empregados, a inovação e a tomada de riscos, pois as ações individuais são orientadas para a consecução de objetivos de alto nível. Para atingir esse alinhamento os líderes devem seguir duas etapas: promover a conscientização de todos os empregados divulgando os objetivos estratégicos de alto nível de maneira compreensível e instituir incentivos e recompensas aos indivíduos e equipes que conseguirem atingir os objetivos propostos;

d) Trabalho em equipe e compartilhamento do conhecimento: novos conhecimentos devem ser gerados, organizados, desenvolvidos e distribuídos em toda a organização. O principal desafio é encontrar maneiras de motivar os indivíduos a documentar suas idéias e conhecimentos e disponibilizá-las aos demais. 


\subsection{Planejamento estratégico e processos}

Nesse contexto de administração estratégica insere-se a orientação por processos. Segundo Hammer (1998), a organização orientada para processos está surgindo como a forma organizacional dominante para o século XXI. Para Hammer e Stanton (1999), a mudança para uma empresa por processos deve estar ligada com uma iniciativa estratégica.

Para Robbins (2002), a organização precisa avaliar seus processos essenciais que, claramente, agregam valor às suas competências. Esses processos transformam material, capital, informação e mão-de-obra em produtos e serviços aos quais os consumidores dão valor. Quando a organização é vista como uma série de processos, que vão desde o planejamento estratégico até o suporte pós-venda, a administração pode determinar qual o valor que cada um desse agrega a organização, podendo, portanto, reavaliar tais processos e, principalmente, reavaliar seu posicionamento estratégico frente ao mercado.

Um negócio, segundo Cruz (2003, p.46), “é uma reunião de três elementos: pessoas, processos e tecnologia da informação, com a finalidade de atender às expectativas do cliente. Os três elementos devem, necessariamente, agregar valor aos insumos que forem usados para produzir o bem ou serviços pois, do contrário, a empresa não conseguirá colocar seus produtos no mercado e, cedo ou tarde, desaparecerá.”

Para criar os novos processos que suportarão um negócio, novo ou já existente, é necessário contextualizá-lo. Para isso é preciso conhecer bem:

- os objetivos do negócio;

- os resultados esperados do negócio;

- quais são os fatores críticos de sucesso do negócio. 
Sem conhecer os objetivos do negócio fica impossível criar os processos que devem suportá-lo. Os objetivos do negócio devem estar diretamente ligados ao plano estratégico de negócio. Dessa forma, os processos também devem estar ligados ao plano estratégico do negócio, direta ou indiretamente. Processos sem ligação com o planejamento estratégico não têm razão de continuar existindo, pois são consumidores de recursos desorganizadores dos demais processos.

A Figura 4 mostra como os processos de negócio estão ligados aos objetivos por meio dos planos operacionais, das metas e do plano estratégico de negócio. Em linhas gerais, o plano operacional de negócio é o planejamento tático, ou seja, o desdobramento do plano estratégico em ações que devem ser executadas para alcançá-lo.

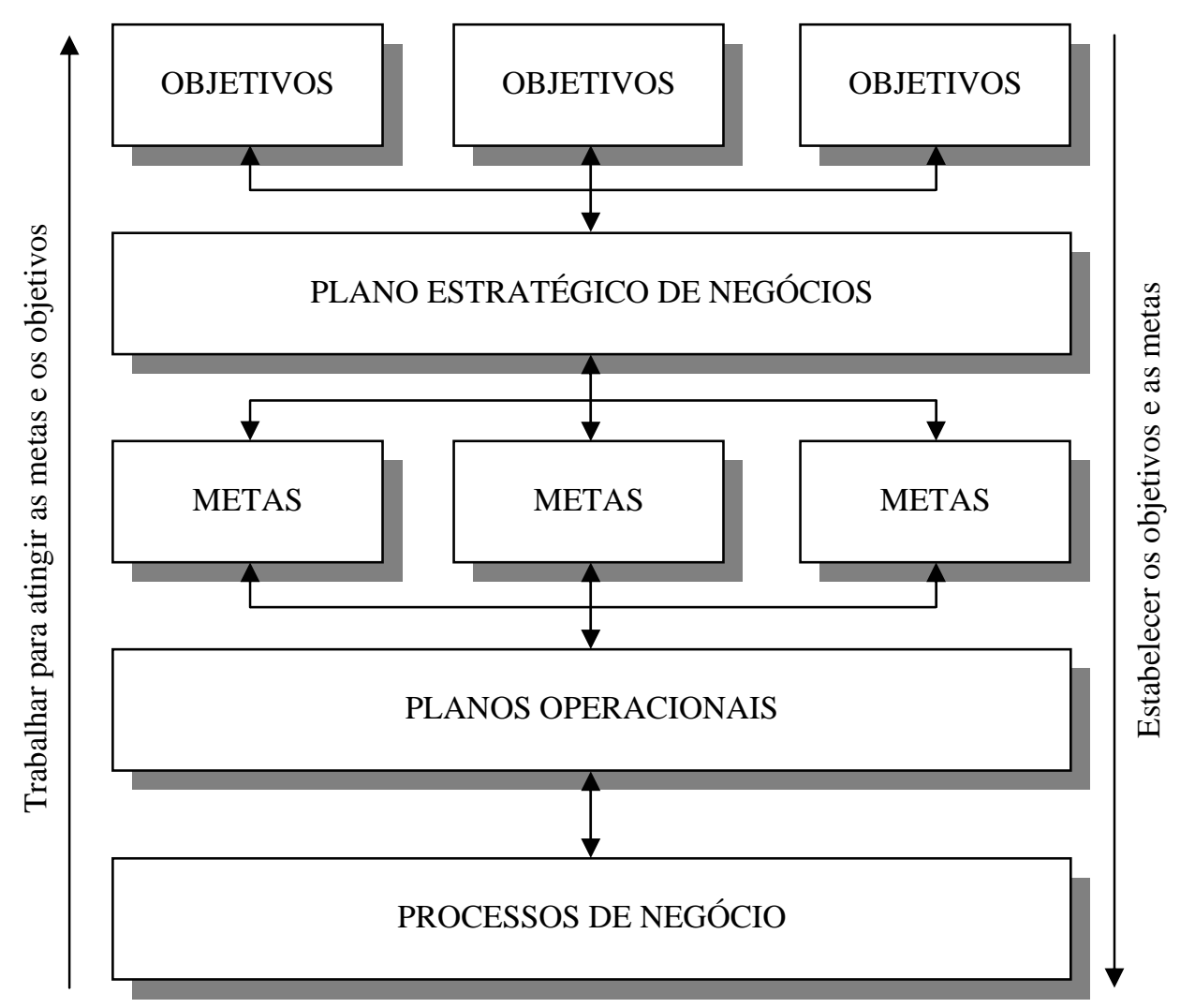

Fonte: Cruz (2003, p.48).

Figura 4 - Envolvimento dos processos com o planejamento estratégico 


\subsection{Considerações finais}

Este capítulo apresentou a importância do planejamento estratégico para uma organização, enfocando também a necessidade de instrumentos para transformar essa estratégia em planos operacionais. O Balanced Scorecard é uma ferramenta capaz de operacionalizar a estratégia através de medidas de desempenho divididas em quatro perspectivas: financeira, do cliente, dos processos internos e do aprendizado e crescimento.

Este capítulo é finalizado mostrando a importância do envolvimento dos processos com o planejamento estratégico, mas antes de tudo torna-se necessário o conhecimento dos objetivos, os resultados esperados e, principalmente, os fatores críticos de sucesso do negócio para que possam ser criados processos de deverão suportá-lo.

\begin{tabular}{|c|c|}
\hline \multicolumn{2}{|c|}{ PLANEJAMENTO ESTRATÉGICO } \\
\hline \multicolumn{2}{|c|}{ MODELO DE GESTÃO ESTRATÉGICA - Balanced Scorecard } \\
\hline $\begin{array}{l}\text { Perspectiva Financeira } \\
\text { • crescimento } \\
\text { • sustentação } \\
\text { • colheita }\end{array}$ & $\begin{array}{l}\text { Perspectiva do Cliente } \\
\text { - atributos dos produtos ou serviços } \\
\text { - relacionamento com os clientes } \\
\text { • imagem e na reputação }\end{array}$ \\
\hline $\begin{array}{l}\text { Perspectiva dos Processos Internos } \\
\text { • gestão operacional } \\
\text { • gestão de clientes } \\
\text { • inovação } \\
\text { • regulatórios e sociais }\end{array}$ & $\begin{array}{l}\text { Perspectiva do Aprendizado e Crescimento } \\
\text { - capital humano } \\
\text { - capital da informação } \\
\text { - capital organizacional }\end{array}$ \\
\hline PROCESS & E NEGÓCIOS \\
\hline
\end{tabular}

Figura 5 - Estrutura do Capítulo 1 
Os problemas que afligem as organizações modernas não são problemas de tarefa. São problemas de processo.

Hammer, 1997

\section{GESTÃO POR PROCESSOS}

Este capítulo propõe-se caracterizar a gestão por processos com uma revisão da literatura. Primeiramente, apresenta-se uma conceituação de processos, mostrando os principais tipos, elementos que os compõem e fase de gerenciamento. Expõem-se as principais diferenças entre uma organização tradicional e uma organização estruturada por processos, as principais dificuldades encontradas para uma transição entre estruturas. Finalmente, apresentam-se os diversos estágios em que as empresas percorrem, desde uma organização puramente funcional até uma organização totalmente estruturada por processos.

\subsection{O que é processo?}

Processo, palavra originária do latim processu, significa “ato de proceder, de ir por diante; maneira pela qual se realiza uma operação, segundo determinadas normas; método, técnica” (FERREIRA, 1986, p.1395).

Todo trabalho importante realizado nas empresas faz parte de algum processo (GRAHAM e LEBARON, 1994). Não existe um produto ou um serviço oferecido por uma empresa sem um processo. 
Em termos gerais, Garvin (1998, p.33) define processo "como uma coleção de tarefas e atividades que juntas - e somente juntas - transforma entradas em saídas”.

Segundo Hammer e Champy (1994, p.24), “processo é um conjunto de atividades com uma ou mais espécies de entrada e que cria uma saída de valor para o cliente”.

“Processo é o conjunto de atividades que tem por objetivo transformar insumos (entradas), adicionando-lhes valor por meio de procedimentos, em bens ou serviços (saídas) que serão entregues e devem atender aos clientes” (CRUZ, 2003, p.63).

Para Harrington (1993), processo é qualquer atividade que recebe uma entrada (input), agrega-lhe valor e gera uma saída (output) para um cliente interno ou externo.

A Figura 6 apresenta um modelo básico das etapas de um processo.

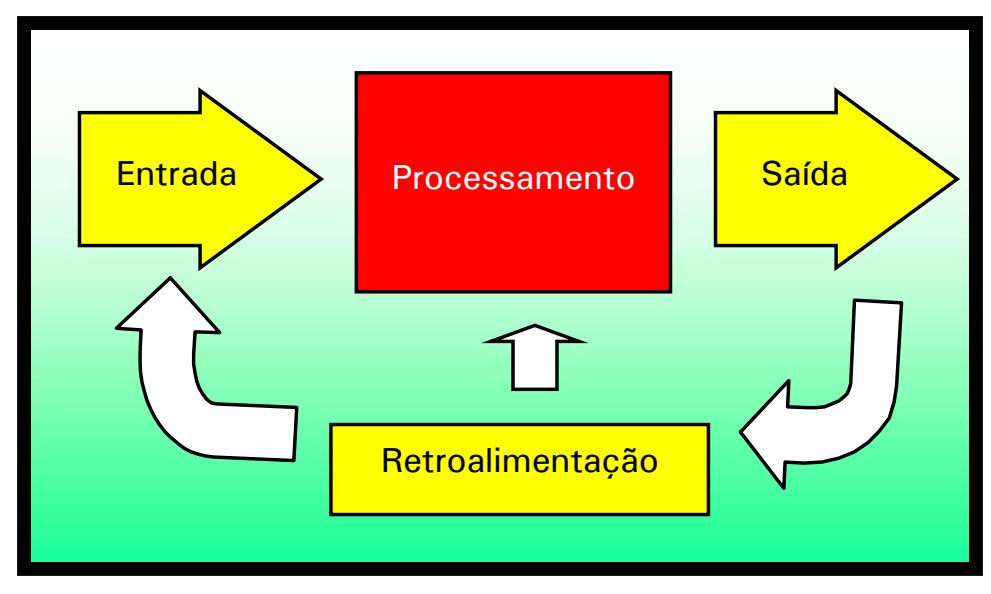

Figura 6 - Etapas básicas de um processo 
Verifica-se, portanto, nas definições que, para organizar as empresas por processos, é necessário colocar o foco no cliente, já que os processos nele começam e terminam.

"Os clientes são pessoas cujo comportamento a empresa deseja
influenciar proporcionando-lhes valor [...] Aparentemente, o relacionamento fundamental entre empresas e clientes tem por base a troca de produtos ou serviços por dinheiro, mas na verdade é muito mais abrangente do que isso. O relacionamento baseia-se em oferecer valor para influenciar e moldar o comportamento” (HAMMER, 1997, p.86). Para o autor, no contexto de negócios, valor é uma solução para o problema do cliente no atendimento de suas necessidades.

Hammer (1997) destaca, ainda, a importância dos clientes para organizar uma empresa por processos uma vez que, para eles os processos constituem a essência de uma empresa. O cliente não está interessado na estrutura organizacional e nas filosofias gerenciais da empresa mas sim nos produtos e serviços produzidos por seus processos.

Isso demonstra a importância dos processos para uma organização, pois eles permitem enxergar uma linha de atividades que começa com o entendimento exato do que o cliente deseja e que termina com o cliente adquirindo aquilo que precisa e deseja de um negócio (GONÇALVES, 2000b).

Manganelli e Klein (1995) dividem essas atividades do processo em três: atividades que agregam valor (importantes para o cliente); atividades de transferência (fazem o fluxo do trabalho atravessar as fronteiras, principalmente funcionais, departamentais ou organizacionais) e atividades de controle (em grande parte, são criadas para controlar as atividades de transferência que atravessam as fronteiras previamente estabelecidas).

A Figura 7 ilustra a evolução - ineficiente e ineficaz - de um processo que atravessa várias fronteiras funcionais e controles existentes na empresa. Para Manganelli e Klein (1995), essas fronteiras criam uma transferência e normalmente dois controles: um controle para a pessoa que está entregando e outro para a que está 
recebendo. Portanto, quanto mais serpenteado o fluxo de trabalho em uma organização, isto é, quanto maior o número de fronteiras que um processo precisa atravessar dentro de uma empresa - maior o número de atividades que não agregam valor dentro desse processo.

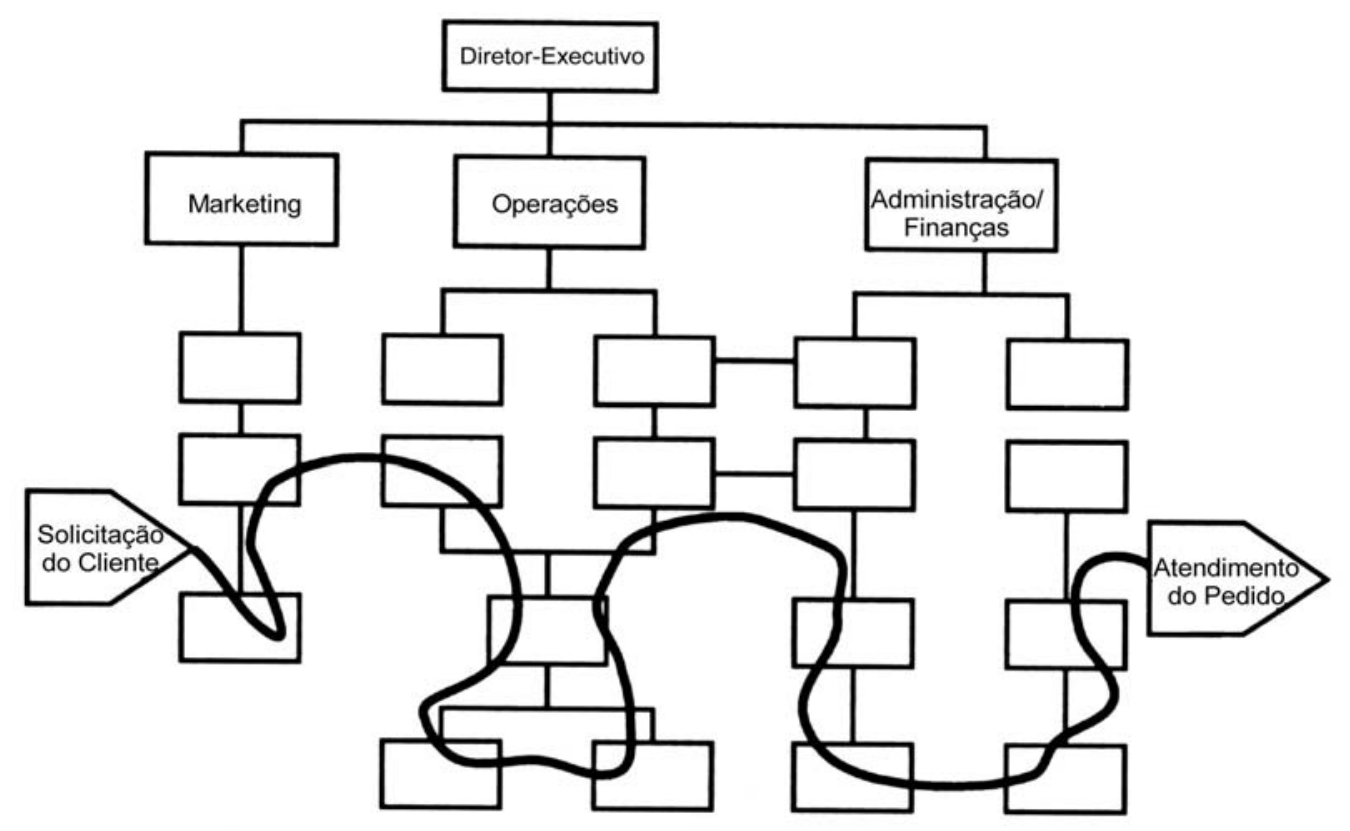

Fonte: Manganelli e Klein (1995).

Figura 7- Fluxo de processos - onde os processos se encaixam em sua organização atual.

Hammer (1997) destaca que as empresas que adotam o foco nos processos não criam nem inventam seus processos. Eles sempre existiram mas em um estado fragmentado, invisível, sem nome e sem gerência, pois os funcionários e supervisores envolvidos nos processos, não tinham consciência de seus processos pelo fato de estarem concentrados em suas próprias tarefas. Com a mudança de foco para processos das organizações, eles simplesmente passam a receber a atenção e o respeito que merecem. 
Nas organizações de pesquisa e desenvolvimento, devido à sua própria finalidade, está presente também o gerenciamento de projetos. Com características semelhantes à divisão por processo, a organização por projeto é formada por equipes multiprofissionais utilizando, como critério, o projeto no qual estão envolvidas em determinado momento, sendo cada projeto, estabelecido como uma unidade organizacional temporária.

Segundo Valeriano (1998, p.19), projeto é entendido como "um conjunto de ações, executadas de forma coordenada por uma organização transitória, ao qual são alocados os insumos necessários para, em um dado prazo, alcançar um objetivo determinado”.

"Projeto se diferencia de processo, pois cada projeto é único, não recorrente, esgotando-se ao fim de sua realização. Ele está ligado ao conjunto das variáveis de desempenho relativas ao valor global do produto, do resultado do projeto" (SALERNO, 1999, p.106).

Para Valeriano (1998), o projeto caracteriza-se por ter objetivo definido, não ser repetitivo, pode ser medido física e financeiramente, ser limitado no tempo e por dar origem a uma atividade ou por concorrer para a expansão ou melhoramento de atividade existente.

\subsection{Tipos de processos}

De maneira geral, em uma empresa, os processos podem ser internos (quando iniciam e terminam dentro da mesma empresa) e externos (quando envolvem diversas empresas diferentes para sua realização). Suas principais características são a interfuncionalidade - a maioria dos processos atravessa as fronteiras funcionais da organização - e o fato de eles terem clientes que podem ser internos ou externos à organização (GONÇALVES, 2000a). 
Os processos utilizam os recursos da organização para oferecer resultados objetivos aos seus clientes (HARRINGTON, 1991), formando-se, com isso, uma coleção de fluxos de valor voltados à satisfação de suas necessidades.

Gonçalves (2000b) apresenta três categorias básicas de processos:

- processos de negócios (ou de cliente), que estão ligados ao funcionamento básico das empresas em suas áreas de atuação e são suportados por outros processos internos, resultando em um produto ou serviço a um cliente externo;

- processos organizacionais (ou de integração organizacional), que são centralizados na organização. São imperceptíveis ao cliente externo, mas são essenciais, garantindo o suporte adequando aos processos de negócio;

- processos gerenciais, que são focalizados nos gerentes e nas suas relações e incluem as ações de medição e ajuste do desempenho da organização.

Quadro 5 - Categorias básicas de processos

\begin{tabular}{|c|c|c|c|}
\hline & $\begin{array}{l}\text { PROCESSOS } \\
\text { DE NEGÓCIO }\end{array}$ & $\begin{array}{c}\text { PROCESSOS } \\
\text { ORGANIZACIONAIS }\end{array}$ & $\begin{array}{l}\text { PROCESSOS } \\
\text { GERENCIAIS }\end{array}$ \\
\hline 莺 & $\begin{array}{l}\text { - Ligados à essência do } \\
\text { funcionamento da organização; } \\
\text { - Típicos da empresa em que operam; } \\
\text { - Variam de organização para } \\
\text { organização. }\end{array}$ & $\begin{array}{l}\text { - } \text { Produzem resultados } \\
\text { imperceptíveis para os clientes } \\
\text { externos; } \\
\text { - São essenciais para a gestão } \\
\text { efetiva dos negócios. }\end{array}$ & $\begin{array}{l}\text { - Ações realizadas pelos } \\
\text { gerentes para dar suporte } \\
\text { aos demais processos de } \\
\text { negócio. }\end{array}$ \\
\hline 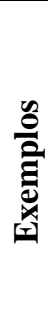 & $\begin{array}{l}\text { - Vendas; } \\
\text { - Desenvolvimento de produtos; } \\
\text { - Distribuição; } \\
\text { - Cobrança; } \\
\text { - Atendimento de pedidos; } \\
\text { - Atendimento de garantia. }\end{array}$ & $\begin{array}{l}\text { - Planejamento estratégico; } \\
\text { - Orçamento empresarial; } \\
\text { - Recrutamento e seleção; } \\
\text { - Compras; } \\
\text { - Treinamento. }\end{array}$ & $\begin{array}{l}\text { - Fixação de metas; } \\
\text { - Avaliação do resultado da } \\
\text { empresa; } \\
\text { - Gestão das interfaces; } \\
\text { - Alocação de recursos. }\end{array}$ \\
\hline & Processos primários & \multicolumn{2}{|c|}{ Processos de suporte } \\
\hline
\end{tabular}

Fonte: Gonçalves (2000b). 
Com relação à capacidade de agregar valor, os processos podem ser divididos em primários - atividades que geram valor ao cliente - e de suporte atividades que apóiam o funcionamento dos processos primários. Os processos organizacionais e gerenciais, como processos de suporte, são considerados processos de informação e decisão (GONÇALVES, 2000a).

Para Cruz (2003), os processos de negócio podem ser divididos em:

- processos industriais: são aqueles ligados diretamente à produção do produto que a organização tem por objetivo disponibilizar para seus clientes, podendo ser divididos em processos industriais de manufatura e processos industriais de serviços;

- processos administrativos (ou suporte): são os processos que dão apoio às áreas de produção e, também, às áreas administrativas de qualquer organização. São conhecidas como atividades meio, que tanto podem ser permanentes como temporárias.

Um processo administrativo jamais deverá prevalecer sobre um processo industrial, pois seria uma inversão de valores, uma vez que os processos industriais dizem respeito ao objetivo fim da organização. No entanto, para Cruz (2003), os processos administrativos não devem ser colocados em segundo plano. Esse tipo de comportamento acaba por comprometer a empresa, ocasionando, entre outros efeitos, o distanciamento do envolvimento de todos os empregados com os processos existentes na organização.

\subsection{Elementos de um processo}

Para analisar e modelar um processo é necessário que se tenham algumas informações sobre o mesmo. Cruz (2003) apresenta uma seqüência de 15 (quinze) elementos que compõem um processo de negócio, à qual denomina Macrofluxo do 
processo. São elas: objetivo do processo; clientes do processo; entradas físicas; entradas lógicas; saídas físicas; saídas lógicas; diretrizes; programa de melhoria contínua; benchmarking; metas; alocação de recursos; mão-de-obra; medição de desempenho; tecnologia da informação; gerente do processo.

A Figura 8 apresenta um diagrama que permite conhecer qualquer processo resumidamente, por meio dos principais elementos contidos (ou não) nele.

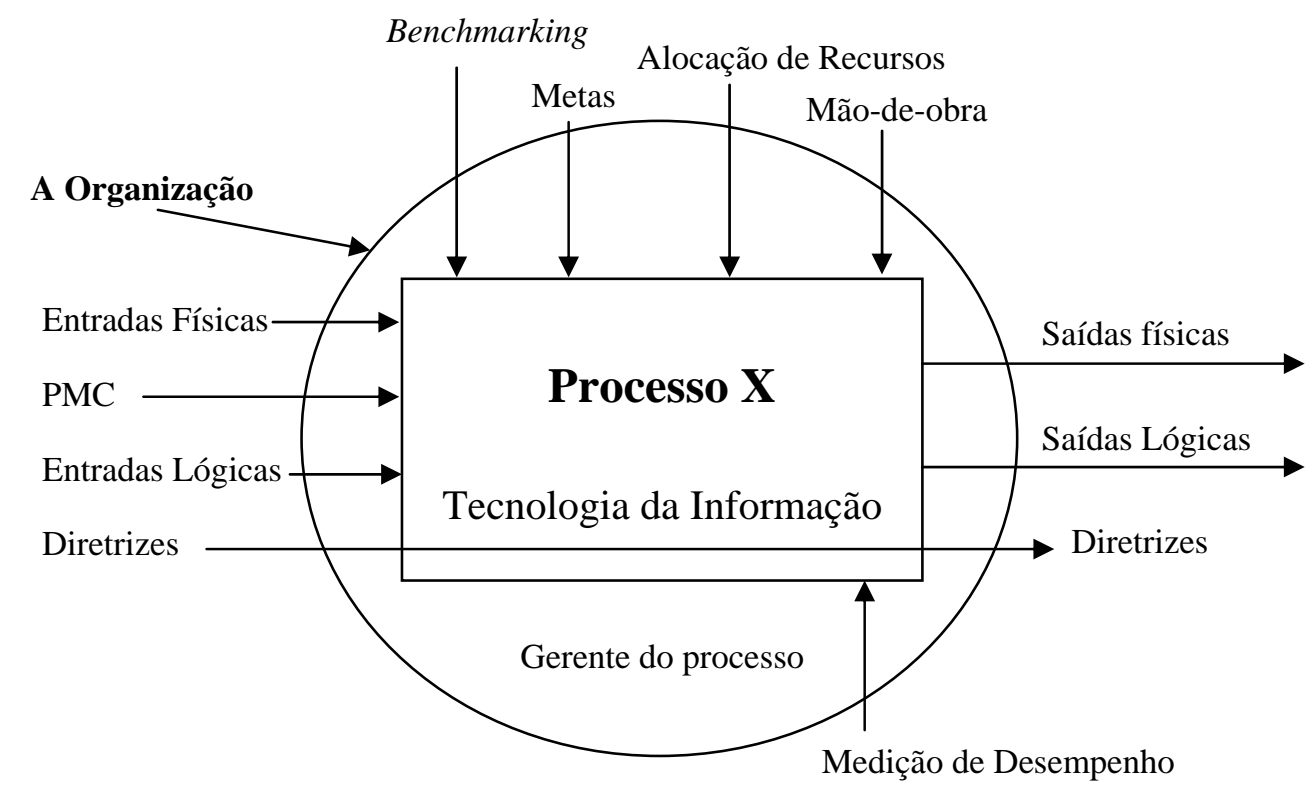

Fonte: Cruz (2003, p.68).

Figura 8 - Macrofluxo do processo de negócio

\subsection{As fases da vida de um processo}

Segundo Cruz (2003), um processo de negócio possui três fases ao longo de seu ciclo (Figura 9). No entanto, essas fases nem sempre são encontradas em todas as empresas que, de alguma forma, se preocupam com processos e muito menos nas que ignoram sua importância. Ressalta, também, a importância das ações de gerenciar e melhorar para uma empresa pois, sem gerenciamento, não pode haver melhoria por 
absoluta ignorância sobre o que está ocorrendo com o processo e sem melhoria não se consegue obter ganhos consistentes de desempenho e produtividade.

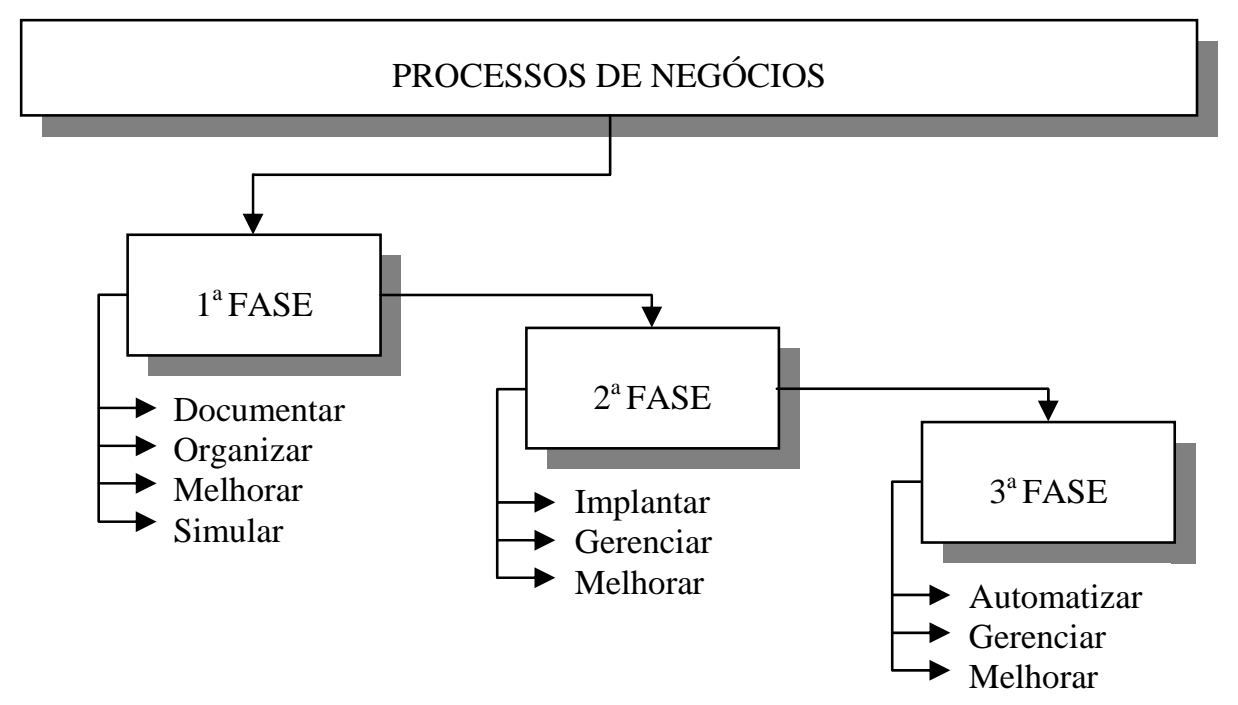

Fonte: Cruz (2003, p.57).

\section{Figura 9 - As três fases na vida de um processo de negócio}

Para Almeida (2002), definir um processo é importante mas não é suficiente, sendo necessário gerenciá-lo. Para isso apresenta algumas fases para seu gerenciamento: escolha do processo, seleção das equipes de melhoria, preparação do processo e operação do processo.

A fase de escolha do processo deverá ser coordenada por alguém, designado pela alta gerência, que tenha um treinamento sobre a metodologia de gerenciamento de processos. Outra opção é a contratação de consultoria externa para treinar as pessoas envolvidas no processo. Uma vez designado o coordenador, a fase seguinte é relacionar os processos que apresentem potencial de geração de benefícios para a empresa, podendo ser feito por meio de entrevistas com a alta gerência ou através de reuniões da alta gerência. Para a escolha dos processos, o item gerenciabilidade dever ser considerado, de modo a ser escolhido um processo que tenha limites 
perfeitamente definidos e conhecidos. Sugere-se que seja escolhido apenas um processo piloto para a aplicação da metodologia.

Uma vez escolhido o processo piloto, o próximo passo é a seleção das equipes de melhoria que irão trabalhar em sua melhoria contínua, a começar pelo “dono” do processo. Sugere-se que seja um dos diretores da organização. Para a escolha das pessoas que irão compor a equipe de melhoria, a palavra de ordem é participação, ou seja, envolvimento daqueles que lidam com o processo em seu dia-a-dia.

Nenhuma organização pode se dar ao luxo de excluir seus gerentes, supervisores,
funcionários, seus peões, das atividades de melhoria, de negar-lhes a
oportunidade de participar da análise e solução dos problemas que eles
enfrentam a cada dia. É inadmissível fazer com que milhares de colegas, ao
baterem o ponto de entrada, pendurem seus cérebros junto com os cartões de
ponto. Entre para o trabalho apenas com seus braços e pernas, fiquem oito horas
fazendo só que o "seu" mestre mandou, sem ao menos saberem por que estão
fazendo aquilo daquela forma, e sem terem a menor noção dos problemas que
advirão, caso façam algo errado (ALMEIDA, 2002, p.41).

É fundamental, também, a participação de pessoas com capacitação e dedicação, competentes, abertas a inovações, que saibam ouvir, que não sejam autoritárias, que sejam cooperativas, dinâmicas, boas comunicadoras e formadoras de opinião.

Escolhida a equipe de melhoria, é necessário treiná-la nos conceitos, definições e ferramentas de trabalho relativas aos processos, bem como seu gerenciamento.

Após o treinamento da equipe de melhoria, o dono do processo executará algumas etapas na preparação do processo:

a) Elaboração da missão da equipe de melhoria, com orientação geral das ações que serão tomadas em todos os setores envolvidos; 
b) Revisão do macrofluxo operacional do processo, que deverá ser desenvolvido por aqueles que estão mais pertos da ação; que melhor conhecem a realidade do processo. Mostra a visão global do processo que está sendo executado;

c) Sumário do processo, constando detalhamento do macrofluxo do processo em um fluxograma, apresentando as atividades envolvidas;

d) Análise das atividades, detalhando cada atividade apresentada, com entradas, processamento e saídas;

e) Definição dos indicadores de desempenho, utilizados para medir a efetividade do processo, podendo ser agrupados em operacionais, qualidade, produtividade e satisfação de clientes ou funcionários;

f) Acordos entre todos os pares de fornecedores/clientes do processo, com reuniões entre clientes e fornecedores das atividades analisadas de forma a buscar a sintonia do processo;

g) Preparo do manual do processo, com disponibilização a toda a organização. Somente o dono do processo poderá alterar o manual, devendo ser documentadas quaisquer alterações introduzidas.

A fase de operação do processo consiste na implementação das propostas apresentadas pela equipe de melhoria. Cabe ao dono do processo, implementar e liderar um sistema gerencial que garanta o acompanhamento sistemático de todos os seus aspectos importantes. Para garantir a qualidade da implementação dessas propostas e seu gerenciamento é necessário o envolvimento de todos os níveis hierárquicos, tanto dos superiores quanto daqueles que participam diretamente do processo. Todos os envolvidos nos processos devem comprometer-se com o mesmo; devem saber de sua importância dentro do processo como um todo. Para isso a participação do dono do processo é importantíssima, devendo montar e liderar o processo gerencial com ações que incentivem o envolvimento e comprometimento de todos para com o processo. 
Belmiro e Reche (2003) apresentam uma seqüência de etapas para implementação de uma gestão orientada por processos (Quadro 6).

\section{Quadro 6 - Etapas de implementação da gestão orientadas por processos}

\begin{tabular}{|c|l|}
\hline Etapas & \multicolumn{1}{|c|}{ Descrição } \\
\hline I & Criação de uma Assessoria de Gestão por Processos; \\
II & Formação da Equipe/Facilitadores; \\
III & Definição/classificação de todos os processos da empresa; \\
IV & Elaboração da cadeia de valores; \\
V & Definição do dono do processo; \\
VI & Modelagem dos processos; \\
VII & Definição dos indicadores de desempenho por processos; \\
VIII & Elaboração das propostas de melhoria; \\
IX & Implementação das ações. \\
\hline
\end{tabular}

Fonte: Belmiro e Reche (2003).

\subsection{Estrutura funcional e estrutura por processos}

Na organização funcional, o trabalho é dividido em funções, departamentos e tarefas. Gonçalves (2000b, p.12) define a organização estruturada por funções como "um conjunto de unidades funcionais verticais isoladas umas das outras, operando em paralelo, sem muita interligação. Nesse modelo, os processos precisam atravessar as fronteiras entre as 'chaminés' funcionais, com sensível perda de tempo, qualidade e capacidade de atendimento”. 
Para Ostroff e Smith (1992), em uma organização funcional:

- a construção primária de desempenho é o indivíduo e seu trabalho;

- a cadeia de comando aumenta em hierarquia funcional;

- o gerenciamento do trabalho é unir os direitos do indivíduo com as tarefas e então medir, avaliar, controlar e recompensar seu desempenho.

Nas organizações tradicionais, os processos são ignorados (HAMMER, 1998), enquanto na organização orientada para processos eles são cuidadosamente projetados, mensurados e entendidos por todos.

Os funcionários têm foco restrito, cabendo unicamente aos gerentes a visão mais geral do quadro. Nas organizações por processos as pessoas têm papéis maiores e mais amplos. Os funcionários trabalham em espírito de equipe juntamente com seus gerentes, com o propósito de alcançar determinados resultados e objetivos definidos pelo cliente (HAMMER, 1998).

Os clientes, por sua vez, nas organizações tradicionais, são uma consideração posterior (HAMMER, 1997), pois a empresa busca desenvolver e produzir um determinado produto ou serviço e tenta vender os resultados aos clientes, ao passo que, nas organizações estruturadas por processo, o cliente deve ser o ponto inicial, sendo qualquer trabalho iniciado a partir da análise de suas necessidades.

Ao procurar estruturarem-se por processos, as empresas acabam descobrindo que é impossível sobrepor um processo integrado a uma organização fragmentada pelo desenho funcional tradicional (HAMMER e STANTON, 1999). As organizações estruturadas por tarefas precisam ser redesenhadas para poder funcionar por processos. Um quadro claro dessa situação deve servir como ponto de partida para todos os subseqüentes alinhamentos de pessoas dentro de uma empresa (GONÇALVES, 2000b). 
A gestão por processos introduz uma visão sistêmica e integrada do trabalho e mostra a interdependência existente entre os fornecedores, executores e clientes, como participantes de uma cadeia de atividades destinadas a gerar resultados organizacionais, situação esta não presente em uma estrutura funcional. Nesse sentido, supervisores, técnicos e pessoal auxiliar passam a ter uma visão ampliada de seus respectivos papéis na organização. As pessoas, ao invés de trabalharem com uma lista de atividades, passam a trabalhar com processos descritos permitindo-lhes a indicação dos seus objetivos, fontes de insumos, produtos e resultados esperados, clientes a serem atendidos e indicadores de desempenho.

Esse novo modelo de gestão, orientado para processos, compreende o planejamento, o acompanhamento e o monitoramento das atividades, de forma sistêmica e integrada, onde o trabalho é dividido e organizado por processos, resultando em um modelo organizacional que possibilite a qualquer dos membros da organização envolvidos nos processos, uma visão global e integrada do fluxo de trabalho, bem como seu total entendimento, independentemente do local onde são executadas as diversas atividades (HAMMER, 1997).

Ostroff e Smith (1992) denominam organização horizontal para as empresas organizadas por processo e apresentam dez princípios básicos para esse tipo de organização:

1) Organizar em torno de processos e não tarefas, isto significa selecionar alguns dos objetivos chaves do desempenho baseados em necessidades de cliente e amarrá-los ao fluxo de trabalho, identificando os processos principais. Baseia-se no estabelecimento de times baseados em cliente, onde cada time fornece uma completa linha de serviços para seus clientes, realizando cada etapa do processo por si mesmo;

2) Nivelar a hierarquia minimizando a subdivisão de fluxos de trabalho e atividades que não agregam valor, eliminando atividades que não adicionam valor ou contribuem para o aumento do desempenho dos objetivos, bem como diminuir, dentro das possibilidades, o número de áreas de atividade em que cada processo está dividido; 
3) Atribuir um líder de processo e o desempenho de processo. Na organização horizontal não desaparece a figura do líder. É designado um líder para cada processo responsabilizando-se pelo seu desempenho. Esses líderes devem auxiliar no processo sem privilégios;

4) Vincular objetivos de desempenho e avaliação à satisfação do cliente. A organização vertical tende a comparar o desempenho com resultados financeiros e focar atenção em cada contribuição das funções de linha. Em contraste, a medida de desempenho horizontal foca na satisfação do cliente. Enquanto as equipes desenvolvem uma compreensão do que necessitam para manter o fluxo do processo, pensa-se em cada área da atividade como um cliente interno, fazendo uma ligação essencial que conduz à satisfação de clientes externos da companhia;

5) Fazer com que as equipes, não as pessoas individualmente, sejam os principais pilares de construção do desenho da organização. Tornar um grupo de trabalho uma equipe não é tão fácil. Uma real equipe, em oposição a um mero grupo de indivíduo com obrigações comuns, usualmente é constituída de 2 a 20 pessoas com habilidades complementares - pessoas comprometidas com um propósito comum e com metas de desempenho específicas e mensuráveis para as quais mantêm responsabilidades mútuas;

6) Combinar atividades gerenciais com atividades não-gerenciais tanto quanto possível. Nas organizações horizontais as atividades gerenciais e não-gerenciais devem ser combinadas de modo que os times consigam ser organizados sobre um fluxo de trabalho, pois as pessoas que desempenham certos tipos de atividades sabem a melhor maneira de melhorá-las e, através de suas experiências e proximidade, buscam novos caminhos para solução de problemas;

7) Tratar múltiplas competências como regra e não como exceção. Nas organizações horizontais, o grande número de habilidades e competências individuais e os conhecimentos individuais dos processos principais auxiliam na capacidade do time de resolver problemas; 
8) Informar e treinar as pessoas em uma base de executar just in time e não em uma base de "necessidade de saber". Nas organizações verticais, as informações são usadas para tomada de decisões e controle gerencial, não para informar a linha de frente ou suporte em seus esforços na melhoria de desempenho. Essas informações são repassadas somente aos gerentes que demonstram "necessidade de saber”. Nas organizações horizontais as informações são fornecidas diretamente a quem implementa as ações necessárias para melhoria de desempenho. Um importante benefício dessa aproximação just in time é que os empregados conhecem como modificar seu próprio comportamento para melhoria de desempenho e como seus novos comportamentos afetam os resultados desejados do negócio;

9) Maximizar contatos com fornecedores e clientes. As organizações horizontais encorajam seus empregados a manterem contatos regulares com fornecedores e clientes;

10) Recompensar o desenvolvimento de habilidades individuais e desempenho da equipe, não apenas o desempenho individual. Nas organizações horizontais o sistema de recompensa e planos de carreiras é baseado em habilidades, valores e comportamentos necessários para o aumento do desempenho da companhia. Enfatiza-se a expansão do papel individual para uma equipe e mais amplamente dentro dos processos.

Quadro 7: Estrutura funcional e estrutura por processos

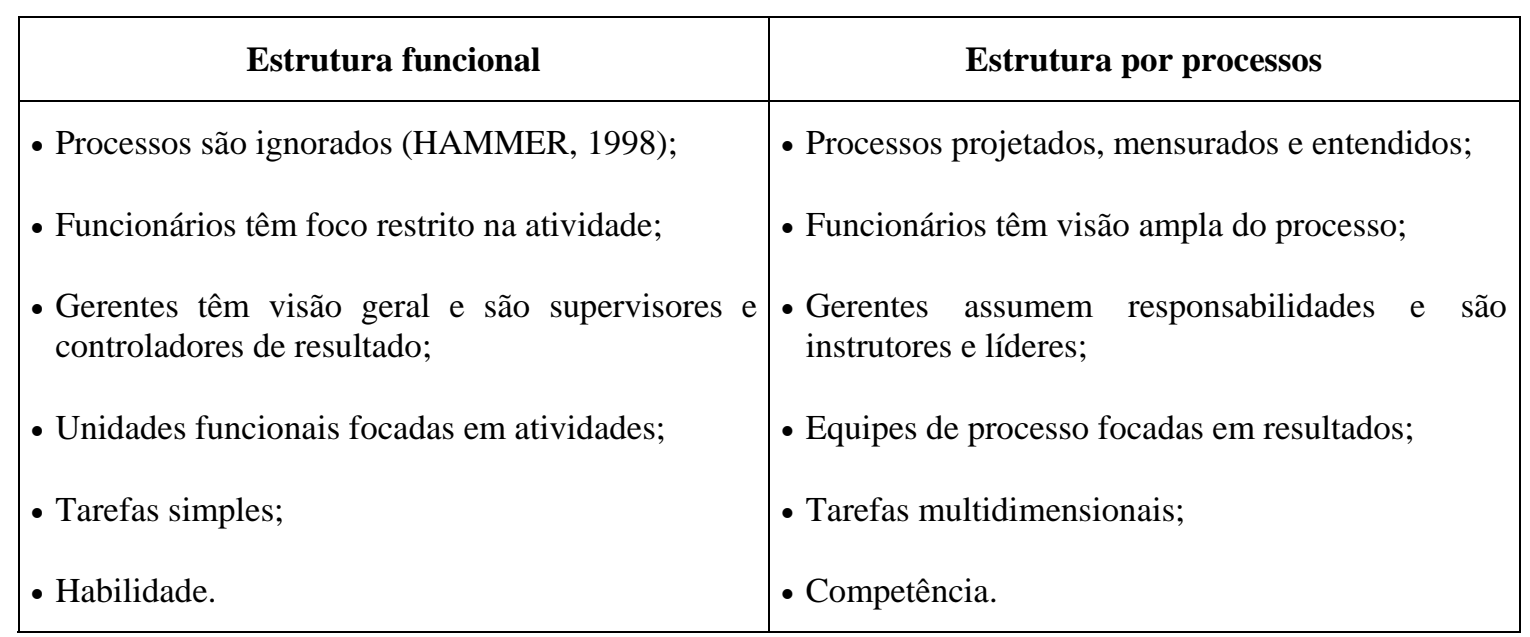




\subsection{Transição para processos}

A mudança de uma organização tradicional (funcional) para processos é muito difícil (HAMMER, 1998), pois as pessoas têm que aprender a pensar de novas formas, compreendendo melhor o negócio, assumindo mais responsabilidades e trabalhando em equipe. Em síntese, é necessário que haja comprometimento de todos para com os objetivos da organização na busca da satisfação do cliente e no conseqüente aumento da competitividade sustentável em um mercado cada vez mais globalizado e dinâmico.

Na adoção da gestão por processos, cada integrante da equipe deve entender claramente seu papel na distribuição de suas responsabilidades de forma a garantir o sucesso do modelo (EMPRESA BRASILEIRA DE PESQUISA AGROPECUÁRIA, 2002a). Os membros da equipe devem estar aptos a cumprir as funções de:

- entender a empresa e seu negócio;

- coletar informações direcionadas ao alcance dos objetivos visados pela gestão por processos;

- identificar as oportunidades de melhorias;

- influenciar mudanças de procedimentos e comportamentos;

- compromissar planos e implantar mudanças para melhorias no processo;

- acompanhar as mudanças para ajustes e garantia do sucesso.

Dos executivos que assumem novas funções de liderança aos gerentes de nível médio que precisam abrir mão da supervisão e começar a orientar os executivos 
que assumem a nova responsabilidade pela satisfação do cliente, todos enfrentam uma nova situação. Todos têm um novo papel e esses novos papéis exigem novas atitudes e habilidades, uma vez que o foco nos processos não ocorre somente na diretoria da empresa, mas principalmente nas linhas de frente, onde as pessoas que executam o verdadeiro trabalho na empresa redirecionam seu pensamento e mudam de comportamento (HAMMER, 1997).

Para Hammer e Stanton (1999), uma mudança para processos não ocorre rapidamente. Nem tudo necessita ser feito de uma vez. Para esses autores a maior resistência está nos executivos seniores funcionais, nos chefes de divisão e em outros membros da alta gerência. Eles vêem a mudança como uma perda da autonomia e poder e se sentem desconfortáveis com o novo estilo gerencial colaborativo. Os trabalhadores da linha de frente, por sua vez, raramente se opõem à mudança para processos, pois se sentem ansiosos com a ampliação de seus trabalhos, aumentando seu interesse por esse novo tipo de estrutura.

Com base em pesquisas conduzidas em uma empresa de telecomunicação, Belmiro e Reche (2003) relatam que, de acordo com os assessores de gestão por processos dessa empresa, o ganho mais importante em uma mudança para processos seria a quebra de barreiras por meio do estabelecimento de processos de comunicação internos mais integrados, obedecendo ao fluxo natural do processo de negócio. "Se as barreiras entre áreas deixassem de existir, tornar-se-ia possível concluir o processo em tempos mais competitivos” (BELMIRO e RECHE, 2003, p.266). Para o consultor executivo da assessoria de gestão por processos dessa empresa, a estrutura baseada em processos prega que na organização flexível e moderna o fator mais importante é a mudança.

Hammer (1997) apresenta quatro pontos básicos para uma empresa caminhar rumo ao foco nos processos:

- Identificar e dar nomes aos processos de uma empresa, o que não deve ser feito sem reflexão. Exige um cuidado rigoroso, a fim de garantir a identificação dos verdadeiros processos. Isso é difícil, pois os processos cruzam fronteiras organizacionais existentes. Muitas organizações enganam a si mesmas e 
simplesmente renomeiam suas unidade funcionais existentes como processos. A identificação do processo exige um novo estilo cognitivo, a capacidade de olhar horizontalmente a organização como um todo, como se vista de fora, e não de cima para baixo;

\section{- Conscientização de todos na empresa desses processos e de sua importância.} Todos precisam reconhecer os processos da empresa, ser capazes de nomeá-los e ter clareza quanto a seus inputs, outputs e o relacionamento entre eles. A adoção do foco nos processos não muda imediatamente as tarefas realizadas pelas pessoas, mas muda sua mentalidade. O trabalho no processo é um trabalho que considera o quadro geral;

- Avaliação dos processos. As empresas precisam identificar as medidas-chave através das quais seus processos serão avaliados. Algumas dessas medidas devem se basear no que é importante para o cliente. Outro conjunto de medidas deve refletir as próprias necessidades da empresa: custos de processo, utilização de ativos e outras questões tipicamente financeiras. As medidas são essenciais não só para saber como o processo está se saindo, mas para direcionar os esforços no sentido de melhorá-los;

- Gestão do processo. O foco nos processos é uma revolução permanente, devendo a empresa continuar focalizando seus processos, de modo a mantê-los afinados com as necessidades do ambiente de negócios, em constante mudança. Uma organização orientada para processos precisa lutar pela melhoria contínua dos processos. Para realizar isso, a empresa precisa gerenciar ativamente seus processos.

Para Gonçalves (1997), mudar a estrutura organizacional da empresa de um modelo funcional para uma empresa por processos implica:

- atribuir a responsabilidade pelo andamento de cada processo essencial a um proprietário de processo;

- minimizar os deslocamentos de pessoas e as transferências de material (para reduzir esperas, erros e cruzamento de fronteiras), organizando as atividades ao longo de processos, e não por funções; 
- maximizar o agrupamento das atividades, empregando equipes multifuncionais e pessoal polivalente;

- diminuir o gasto de energia por meio de atividades como, por exemplo, reunir as partes da empresa em menor número de locais ou empregar maciçamente os recursos de tecnologia de informação para reduzir o transporte, armazenagem e deslocamento dos recursos e materiais empregados nos processos essenciais.

Percebe-se que as pessoas têm papel fundamental na mudança de uma organização para processos. Pelo fato de as organizações por processos exigirem que as pessoas trabalhem de maneira tão diferente, é freqüente perceber que faltam as ferramentas e modelos sociais, psicológicos e humanos para ajustar os grupos internos às novas condições (GONÇALVES, 2000b).

\subsubsection{Mudança organizacional}

"Mudança organizacional é qualquer transformação de natureza estrutural, estratégica, cultural, tecnológica, humana ou de qualquer outro componente capaz de gerar impacto em partes ou no conjunto da organização” (WOOD JUNIOR, 1995, p.190).

Para fazer face à crescente competitividade, cumprir novas leis ou regulamentações, introduzir novas tecnologias ou atender a variações nas preferências de consumidores ou de parceiros as organizações estão sendo obrigadas a mudar (HERNANDEZ e CALDAS, 2001).

Gonçalves (1998) destaca que, embora sejam muitas as abordagens com que o tema mudança organizacional tem sido tratado por estudiosos da área organizacional, parece haver um consenso entre os autores quanto ao fato de que as 
alterações do ambiente externo têm forçado as organizações a promoverem mudanças em seus sistemas de gestão com freqüência e velocidade cada vez maiores.

Essa mudança, imposta pelo ambiente competitivo, força as organizações a adequarem seus modelos de gestão a essa nova realidade, alinhando seus processos, suas competências e sistemas de informação aos objetivos estratégicos da empresa. Evidencia-se o achatamento da hierarquia e a eliminação dos cargos, diminuindo o gerenciamento hierárquico, graças à tecnologia de informação que proporciona o desenvolvimento de equipes auto-geridas e o envolvimento dos funcionários nos processos.

Para Zarifian (2001), essas novas características organizacionais objetivam estimular as interações entre equipes e possibilitar ganhos em termos de desempenho graças à estruturação sistemática de uma comunicação interequipes e interocupações.

Robbins (2002) apresenta seis forças específicas que estimulam a mudança: a natureza da força de trabalho, a tecnologia, os choques econômicos, a competição, as tendências sociais e a política internacional. Nesse contexto, essas mudanças podem ser inseridas em uma organização por meio de quatro categorias (ROBBINS, 2002):

- mudar a estrutura, envolve alterações nas relações de autoridade, mecanismos de coordenação e replanejamento do trabalho;

- mudar a tecnologia, significa mudança na maneira pela qual o trabalho é realizado e a introdução de novos equipamentos, ferramentas ou métodos operacionais para a realização desse trabalho;

- mudar as instalações físicas, envolve mudanças no arranjo físico do espaço de trabalho, como de instalação de equipamentos, alterações de divisórias e paredes;

- mudar as pessoas, refere-se à modificação de atitudes, habilidades, expectativas, percepções e comportamentos dos funcionários de modo que esses trabalhem mais efetivamente em conjunto. 
Ferlie et al. ${ }^{1}$ (1999 apud MENDES e GUIMARÃES, 2002), utilizando como critérios a intensidade e a extensão com que ocorrem mudanças nas organizações, propuseram uma classificação para as mudanças organizacionais:

- mudança incremental: mudança de menor porte e produz efeitos de modificações pontuais, normalmente sobre uma função ou unidade organizacional;

- mudança estratégica: é um tipo de mudança que causa impacto em muitas partes da organização, afetando um ou mais sistemas organizacionais, tais como estratégico, estrutural e de controle;

- mudança transformadora: é descrita como mudança de cima para baixo, conduzida por motivos políticos e pela necessidade de direcionar os recursos e melhorar a eficiência. Os efeitos dessa mudança atingem toda a organização, interferem nas relações de poder e na cultura organizacional, além de implicar a inovação de produtos ou serviços.

Para Silva e Vergara (2002), a comunicação na mudança organizacional, tem papel fundamental e não pode ser vista como um simples mecanismo de transmissão de mensagem e de convencimento das pessoas sobre as intenções da organização. São múltiplas as identidades dos indivíduos que são afetadas pelas situações de mudança devendo, as organizações, considerarem alguns pontos como sentimentos, dúvidas, inseguranças, anseios ao efetuarem seu planejamento de gestão das mudanças.

Gonçalves (1998) destaca que as técnicas de mudança organizacional empregadas ultimamente não contribuem muito para a preservação do equilíbrio entre as expectativas dos empregados em relação a sua participação nas decisões referentes a seus trabalhos e da própria empresa.

${ }^{1}$ FERLie, E.; ASHBURnER, L.; FITZGERALD, L. e PITTIGREW, A. (1999). The new public management in action. London: Oxford University Press. 
Observa-se que as mudanças organizacionais geralmente são reativas quando deveriam ser resultado de previsão. “A empresa orientada para o cliente e que deseja criar uma boa impressão nos seus 'momentos da verdade' deve ser organização para a mudança. Por exemplo, deve achatar a pirâmide, eliminar níveis hierárquicos de responsabilidade para conseguir responder direta e rapidamente às demandas dos seus clientes” (GONÇALVES, 1998, p.13).

Hernandez e Caldas (2001) também destacam que as soluções para as resistências impostas a essas mudanças, são apresentadas na literatura, sem grandes variações, como uma lista de regras desenhadas para superar comportamentos resistentes adotados por empregados descontentes que podem impedir ou ameaçar o esforço de transformação. Apresentam um conjunto de pressupostos sugeridos pela literatura gerencial e acadêmica que, segundo eles, deveriam ser revisados, conforme apresentado no Quadro 8.

\section{Quadro 8 - Pressupostos clássicos sobre resistência à mudança e possíveis contrapressupostos}

\begin{tabular}{|c|c|}
\hline Pressupostos & Contrapressupostos \\
\hline $\begin{array}{l}\text { - A resistência à mudança é um “fato de vida” e } \\
\text { deve acontecer durante qualquer intervenção } \\
\text { organizacional. }\end{array}$ & $\begin{array}{l}\text { - A resistência é escassa/somente acontecerá em } \\
\text { circunstâncias excepcionais; } \\
\text { - Ao tentar prevení-la, os agentes de mudança acabam } \\
\text { contribuindo para sua ocorrência ou agravamento; } \\
\text { - A resistência é um comportamento alardeado pelos } \\
\text { detentores de poder e pelos agentes de mudança } \\
\text { quando são desafiados em seus privilégios ou ações. }\end{array}$ \\
\hline $\begin{array}{l}\text { - A resistência à mudança é maléfica aos esforços } \\
\text { de mudança organizacional. }\end{array}$ & $\begin{array}{l}\text { - A resistência é um fenômeno saudável e } \\
\text { contributivo; } \\
\text { - A resistência é usada como uma desculpa para } \\
\text { processos de mudança fracassados ou } \\
\text { inadequadamente desenhados. }\end{array}$ \\
\hline $\begin{array}{l}\text { - Os seres humanos são naturalmente resistentes à } \\
\text { mudança. }\end{array}$ & $\begin{array}{l}\text { - Os seres humanos resistem à perda, mas desejam } \\
\text { a mudança; tal necessidade tipicamente se } \\
\text { sobrepõe ao medo do desconhecido. }\end{array}$ \\
\hline $\begin{array}{l}\text { - Os empregados são atores organizacionais com } \\
\text { maior probabilidade de resistir à mudança. }\end{array}$ & $\begin{array}{l}\text { - A resistência - quando ocorre - pode acontecer entre } \\
\text { os gestores, agente de mudança e empregados. }\end{array}$ \\
\hline $\begin{array}{l}\text { - A resistência à mudança é um fenômeno } \\
\text { grupal/coletivo. }\end{array}$ & $\begin{array}{l}\text { - A resistência é tanto individual quanto coletiva - } \\
\text { a resistência vai variar de uma pessoa para outra, } \\
\text { em função de muitos fatores situacionais e de } \\
\text { percepção. }\end{array}$ \\
\hline
\end{tabular}

Fonte: Hernandez e Caldas (2001). 
Por outro lado, segundo Robbins (2002), as organizações também são conservadoras, resistindo ativamente às mudanças, e identifica seis principais fontes de resistência:

- inércia estrutural: possuem mecanismos internos que produzem a estabilidade sendo as pessoas moldadas e orientadas a se comportar de determinadas maneiras de modo a se ajustarem à organização;

- foco limitado de mudança: as organizações são formadas por diversos subsistemas interdependentes, não podendo ocorrer mudanças em um deles sem afetar os demais. Mudanças limitadas aos subsistemas tendem a ser anuladas pelo sistema mais amplo;

- inércia de grupo: mesmo que os indivíduos queiram mudar seu comportamento, as normas de grupo agem como limitadores;

- ameaça à especialização: as mudanças nos padrões organizacionais podem ameaçar a exclusividade de alguns grupos especializados;

- ameaça às relações de poder estabelecidas: qualquer redistribuição de autoridade para tomada de decisões pode ameaçar as relações de poder já estabelecidas dentro da organização;

- ameaça às alocações de recursos estabelecidas: nas organizações, os grupos que controlam algum tipo de recursos que possa ser cortado freqüentemente vêem a mudança como uma ameaça.

Para Kotter (1997), a grande dificuldade em uma mudança organizacional reside na complexidade da tarefa de convencer todo um coletivo de indivíduos a acreditar nos benefícios da mudança e conseguir retirá-lo de sua zona de conforto para uma outra lógica de atuação com novos valores, propósitos, processos, 
sistemas, conhecimentos etc. Apresentam-se erros comuns que causariam fracasso em um projeto de mudança organizacional e propõe alternativas para evitá-los ou minimizálos:

- assegurar que uma parte relevante da organização tenha o real entendimento da necessidade de mudança que está por vir;

- garantir a autonomia e a influência para o grupo responsável pela coordenação do processo de transformação;

- esse grupo deve definir a estratégia de atuação e a visão de futuro almejada, comunicando-as de forma abrangente e expressiva para a organização;

- deve-se ter a preocupação que essa visão corresponda às expectativas e possibilidades viáveis da organização, não se constituindo em um sonho utópico desacreditado pelos funcionários;

- manter a motivação necessária dos empregados durante o processo de mudança, que tendem a ser longos e cansativos, tendendo a serem difíceis de serem percebidos pelos funcionários;

- definir objetivos de curto prazo, que criem a percepção da agregação de valor que a mudança gerará;

- monitorar continuamente os processos de implantação, de forma a assegurar a continuidade da postura pró-mudança dos funcionários, evitando que ocorra uma regressão do projeto e combatendo os obstáculos entendidos como forças contrárias à mudança;

- conscientizar as pessoas de que os resultados obtidos foram conseguidos por meio dos esforços coletivos e da aceitação da mudança, de modo a garantir que essas não voltem a agir como antes, incorporando, assim, a mudança à cultura da organização. 


\subsection{Estágios de evolução das empresas voltadas para processos}

As empresas, quando tentam mudar de uma organização por tarefas para uma organização orientada por processos esbarram em algumas dificuldades por não saberem exatamente o que faz funcionar bem a empresa orientada por processos.

\footnotetext{
Muitas empresas querem organizar-se por processo, mas não têm uma noção clara dos passos a seguir e das providências que devem ser tomadas. Outras não estão certas da decisão a tomar a respeito da sua estruturação por processos e podem beneficiar-se de um raciocínio que as ajude a decidir. Existem também as empresas que não sabem ao certo o que significa serem organizadas por processos e as que não têm certeza se a sua forma organizacional atual é adequada para a gestão por processos. Finalmente, ainda, as empresas que precisam de mais esclarecimentos sobre o assunto para que possam analisar as vantagens da gestão por processos (GONÇALVES, 2000b, p.9).
}

Gonçalves (2000b) apresenta cinco estágios evolutivos para uma empresa em direção à organização por processos que vai de um modelo puramente funcional até o modelo essencialmente baseado em processos. As posições intermediárias correspondem a situações em que as empresas apresentam níveis variados de características típicas de organizações por processos. Atualmente, cada empresa se encontra em algum desses estágios e pode decidir passar para outro estágio que seja mais adequado às suas operações e perspectivas. Algumas empresas realmente evoluem de um estágio para outro ao longo de um trajeto. Outras passam diretamente de uma posição pouco evoluída para outra bem mais avançada. 


\section{Quadro 9 - Os estágios da evolução para a organização por processos}

\begin{tabular}{|c|c|c|c|c|c|}
\hline & \multicolumn{5}{|c|}{ Etapas } \\
\hline & $\mathbf{A}$ & B & $\mathbf{C}$ & $\mathbf{D}$ & $\mathbf{E}$ \\
\hline Onde estamos & Processos, que processos? & $\begin{array}{l}\text { Identificamos nossos } \\
\text { processos, subprocessos e } \\
\text { subsubprocessos. }\end{array}$ & $\begin{array}{l}\text { Melhoramos os processos } \\
\text { essenciais. }\end{array}$ & $\begin{array}{l}\text { Redistribuímos nossos } \\
\text { recursos ao longo de } \\
\text { nossos processos } \\
\text { essenciais e atribuímos a } \\
\text { responsabilidade a um } \\
\text { process owner. }\end{array}$ & $\begin{array}{l}\text { Nossa organização foi } \\
\text { desenhada pela lógica dos } \\
\text { nossos rocessos } \\
\text { essenciais. }\end{array}$ \\
\hline Comentários & $\begin{array}{l}\text { As empresas sequer se } \\
\text { deram conta; } \\
\text { Em geral, as empresas } \\
\text { percebem apenas os } \\
\text { processos de manufatura, } \\
\text { os outros processos são } \\
\text { acessórios. }\end{array}$ & $\begin{array}{l}\text { O foco do esforço ainda } \\
\text { está nas funções; } \\
\text { Os processos são } \\
\text { enquadrados na estrutura } \\
\text { funcional; } \\
\text { A abordagem é ampla } \\
\text { demais; } \\
\text { A forma de trabalho é } \\
\text { provavelmente ainda } \\
\text { antiga. }\end{array}$ & $\begin{array}{l}\text { As empresas ainda } \\
\text { raciocinam por funções, } \\
\text { mesmo que conheçam } \\
\text { bem seus processos; } \\
\text { O uso de case managers } \\
\text { pode melhorar o contato } \\
\text { com o cliente; } \\
\text { O poder ainda reside nas } \\
\text { unidades verticais. }\end{array}$ & $\begin{array}{l}\text { Ainda é um remendo, } \\
\text { construído sobre uma } \\
\text { estrutura antiquada; } \\
\text { As empresas começam a } \\
\text { obter resultados da ênfase } \\
\text { em processos, mas com } \\
\text { um alto desconforto na } \\
\text { organização; } \\
\text { Implantação da nova } \\
\text { organização. }\end{array}$ & $\begin{array}{l}\text { É a forma de organização } \\
\text { indicada para a gestão por } \\
\text { processo; } \\
\text { Áreas funcionais } \\
\text { praticamente não existem; } \\
\begin{array}{l}\text { As metas e métricas são } \\
\text { definidas para os } \\
\text { processos. }\end{array}\end{array}$ \\
\hline $\begin{array}{l}\text { Até onde dá para } \\
\text { ir em termos de } \\
\text { negócio }\end{array}$ & $\begin{array}{l}\text { Enquanto o assunto é pura } \\
\text { manufatura, as chances de } \\
\text { aperfeiçoamento radical } \\
\text { são limitadas. }\end{array}$ & $\begin{array}{l}\text { Aperfeiçoamento } \text { de } \\
\text { gargalos e obtenção de } \\
\text { melhoras de eficiência } \\
\text { pontuais. }\end{array}$ & $\begin{array}{l}\text { Aperfeiçoamento dos } \\
\text { processos essenciais, } \\
\text { cortando as atividades e } \\
\text { funções que não agregam } \\
\text { valor. }\end{array}$ & \begin{tabular}{lcr} 
Gestão & de & \multicolumn{2}{c}{ alguns } \\
processos & isolados e \\
integração & com processos \\
auxiliares.
\end{tabular} & $\begin{array}{lcc}\text { Gestão integrada } & \text { dos } \\
\text { processos essenciais. } & \end{array}$ \\
\hline
\end{tabular}

Fonte: Gonçalves, 2000b. 
No estágio A estão aquelas empresas que ainda não deram passos decididos em direção à estruturação por processos. Algumas se questionam sobre a validade de adotar uma estrutura por processos, outras só conseguem perceber os seus processos de manufatura, mas existem também aquelas empresas que, por diversos motivos, não chegaram a considerar seriamente a idéia de se reestruturar. São empresas que ainda precisam passar por uma etapa de conscientização a respeito do assunto. Para essas empresas, as chances de uma mudança radical são muito limitadas.

No estágio B as empresas já têm seus processos e subprocessos identificados, porém o foco do esforço ainda está centrado nas funções. Seus processos são enquadrados na estrutura funcional e geralmente empregam formas de trabalho antigas. As empresas dessa categoria limitam-se a aperfeiçoar os gargalos e obter mais eficiência operacional. Seu grande desafio é o mapeamento dos seus processos e a identificação dos processos essenciais em torno dos quais se organizar.

No estágio C estão as empresas que, embora já tenham identificado seus processos e melhorado seus processos essenciais, ainda raciocinam por funções. Nessas empresas, o poder ainda se concentra nas unidades verticais, que resistem fortemente à idéia de "horizontalizar" a gestão. Geralmente, o máximo que podem tentar é aperfeiçoar seus processos essenciais, acrescentando-lhes tecnologia e cortando as atividades e funções que não agregam valor para o cliente final. Em termos de passos adiante, podem adotar novos critérios para redistribuir seus recursos, de preferência, em função dos seus processos essenciais, e não das unidades verticais, e atribuir cada processo essencial a um process owner.

No estágio D as empresas já tomaram todas as providências das etapas anteriores. Geralmente, distribuem seus recursos ao longo de seus processos essenciais e atribuem a responsabilidade da gestão de cada processo essencial a um process owner. No entanto, ainda trabalham com estruturas antiquadas e, apesar de estarem começando a obter resultados, a ênfase em processos provoca um alto desconforto na organização. Em termos de negócios, podem conseguir aperfeiçoar bastante o desempenho de processos isolados, integrando-os aos processos auxiliares. Sua grande tarefa, a partir desse ponto, é desenvolver um novo modelo estrutural, rompendo com as principais 
funções, reformulando os referenciais e os mecanismos de gestão e, finalmente, implantando a nova organização.

No estágio $\mathbf{E}$ as empresas já foram desenhadas pela lógica dos processos essenciais. Muitas vezes, são empresas novas, que não têm compromissos estruturais e organizacionais com o passado e que surgem dentro de novos referenciais de organização e de negócio. São empresas capazes de realizar a gestão integrada de seus processos essenciais e de colher os resultados dessa integração. Sua grande tarefa é a monitoração permanente da definição do seu negócio e o ajuste dos processos adequados para seu negócio sempre que necessário, adequando a organização a cada momento, como um organismo vivo.

Para Gonçalves (2000b), a principal utilidade desse modelo de classificação das empresas é a identificação do estágio em que se encontra a empresa de modo a ser possível avaliar como ela se situa em relação às demais e com respeito às expectativas dos seus dirigentes. Ele pode sugerir as providências necessárias para que a empresa mude de etapa e indicar o esforço necessário para essa transformação. É possível, também, utilizar esse modelo para avaliar o nível de preparo da alta gestão em função da etapa em que a empresa está e do desafio de mudar de etapa.

\subsection{Considerações finais}

Este capítulo apresentou os principais conceitos de processos por meio de uma revisão bibliográfica, mostrando como podem ser divididos os processos dentro de uma organização. Analisaram-se os principais elementos que compõem um processo de negócio e as principais fases da vida de um processo. Foram expostas as principais diferenças entre uma estrutura funcional e uma estrutura por processos e dificuldade na transição de uma estrutura para outra.

Finalmente, apresentam-se os estágios evolutivos de uma organização voltada para processos. 
Quadro 10 - Tópicos associados à gestão por processos

\begin{tabular}{|c|c|}
\hline Processo & Entrada $\rightarrow$ transformação $\rightarrow$ saída $\rightarrow$ retroalimentação \\
\hline Tipos de um processo & $\begin{array}{l}\text { - Processos de negócios; } \\
\text { - Processos organizacionais; } \\
\text { - Processos gerenciais. }\end{array}$ \\
\hline Elementos de um processo & $\begin{array}{l}\text { Objetivos, clientes, entradas, saídas, diretrizes, melhoria } \\
\text { contínua, benchmarking, alocação de recursos, mão-de- } \\
\text { obra, medição de desempenho, tecnologia da } \\
\text { informação, gerência. }\end{array}$ \\
\hline Fases da vida de um processo & $\begin{array}{l}\text { • escolha do processo; } \\
\text { • seleção das equipes de melhoria; } \\
\text { • preparação do processo; } \\
\text { • operação do processo. }\end{array}$ \\
\hline Estruturas & $\begin{array}{l}\text { - Funcional; } \\
\text { • Por processo. }\end{array}$ \\
\hline Estágios evolutivos para processos & $\begin{array}{l}\text { A - Definir o que é processo; } \\
\text { B - Identificar os principais processos; } \\
\text { C - Melhorar os processos essenciais; } \\
\text { D - Redistribuir recursos ao longo dos processos e } \\
\text { atribuir responsabilidade a um process owner; } \\
\text { E - Organização desenhada pela lógica dos processos } \\
\text { essenciais. }\end{array}$ \\
\hline
\end{tabular}




\section{ESTUDO DE CASO}

Este Capítulo tem por objetivo apresentar a contextualização prática da revisão bibliográfica demonstrada nos Capítulos 2 e 3.

De início é apresentada a empresa, alvo de pesquisa deste trabalho. Com o aprofundamento da pesquisa de campo, este capítulo mostra as particularidades de seu planejamento estratégico, seu modelo de gestão estratégica, baseado no Balanced Scorecard e como os processos inserem-se nesse contexto estratégico.

\subsection{Desenvolvimento da pesquisa}

O estudo de caso deste trabalho foi realizado na Empresa Brasileira de Pesquisa Agropecuária - EMBRAPA, mais especificamente no Centro Nacional de Pesquisa e Desenvolvimento de Instrumentação Agropecuária - CNPDIA, uma de suas quarenta unidades de pesquisa, localizada na cidade de São Carlos, estado de São Paulo.

A presente pesquisa, ocorrida no período de setembro de 2001 a junho de 2004, é resultado da participação e acompanhamento da proposta de implantação de um modelo de gestão por processos como forma de adequar a estrutura organizacional da 
empresa, com vistas ao alcance da excelência no cumprimento da sua missão institucional.

Em setembro de 2001, a empresa ofereceu um treinamento corporativo aos seus funcionários, contemplando dois participantes para cada unidade de pesquisa da empresa, no qual houve participação do presente pesquisador.

A Oficina sobre Gestão por Processos para Consultores Internos da Embrapa capacitou seus participantes com relação à metodologia proposta para implantação do modelo pela empresa, visando fornecer informações para o desenvolvimento e aplicação da referida metodologia de gestão por processos nas unidades às quais pertencem.

Os objetivos principais da Oficina de Trabalho foram:

- divulgar, para os empregados participantes, a forma de organização e divisão do trabalho por processo;

- instrumentalizar pessoas nas unidades para atuar na coordenação da mudança nas formas de organização do trabalho e na multiplicação da própria metodologia;

- capacitar dirigentes, supervisores, líderes formais e informais e outros responsáveis pela gestão da Embrapa na aplicação da metodologia de gestão de processos;

- criar condições para a definição de ações para implementação da gestão por processo nas Unidades Descentralizadas da Embrapa.

Como forma de dar continuidade ao processo de difusão da metodologia, a empresa criou, por meio da intranet e correio eletrônico, um canal de comunicação, no qual os funcionários que participaram da Oficina de Gestão por Processos e demais interessados, pudessem trocar experiências, apresentando as dificuldades e progressos em relação à implantação da metodologia em suas unidades de origem. 
Ao longo do período da pesquisa, o pesquisador também esteve envolvido em comissões de análise e melhoria de processos propostos pela unidade, as quais muito contribuíram para a efetivação desta pesquisa.

\subsection{A Empresa Brasileira de Pesquisa Agropecuária - Embrapa}

A Empresa Brasileira de Pesquisa Agropecuária - Embrapa é uma instituição de pesquisa e desenvolvimento vinculada ao Ministério da Agricultura, Pecuária e Abastecimento, criada em 26 de abril de 1973.

A empresa está sob a coordenação do Sistema Nacional de Pesquisa Agropecuária - SNPA, constituído por instituições públicas federais, estaduais, universidades, empresas privadas e fundações que, de forma cooperada, executam pesquisas nas diferentes áreas geográficas e campos do conhecimento científico (EMPRESA BRASILEIRA DE PESQUISA AGROPECUÁRIA, 2004).

Tem como missão "viabilizar soluções para o desenvolvimento sustentável do agronegócio brasileiro por meio de geração, adaptação e transferência de conhecimentos e tecnologias, em benefício da sociedade” (EMPRESA BRASILEIRA DE PESQUISA AGROPECUÁRIA, 1998).

Sua visão é ser uma empresa de referência no Brasil e no exterior, reconhecida pela:

- excelência de sua contribuição técnico-científica;

- capacidade de catalisar e viabilizar parcerias e novos negócios de base tecnológica; 
- capacidade de oferecer soluções adequadas e oportunas para o mercado e para a sociedade;

- estrutura leve e ágil, centrada na atividade-fim.

Por meio de quatro objetivos globais a Embrapa busca cumprir sua missão apresentada em seu III Plano Diretor:

- Viabilizar soluções tecnológicas para o desenvolvimento de um agronegócio competitivo em uma economia global;

- Viabilizar soluções tecnológicas para o agronegócio, que promovam a sustentabilidade das atividades econômicas com o equilíbrio ambiental;

- Viabilizar soluções tecnológicas que contribuam para diminuir os desequilíbrios sociais;

- Viabilizar soluções tecnológicas para fornecimento de matérias-primas e alimentos que promovam a saúde e a melhoria do nível nutricional e da qualidade de vida da população.

Presente em quase todos os Estados da Federação, a Embrapa dispõe de 8.619 empregados, dos quais 2.221 são pesquisadores com alta qualificação. Seu orçamento anual possui valor aproximado de R 660 milhões. A Embrapa atua por intermédio de 40 Centros de Pesquisa distribuídos nas diversas regiões do Brasil e 11 Unidades Centrais integrantes da administração superior da Empresa, localizadas no edifício-sede da Embrapa, em Brasília, às quais compete planejar, supervisionar, coordenar e controlar as atividades relacionadas à execução de pesquisa agropecuária e à formulação de políticas agrícolas. 
As Unidades Centrais da Embrapa são:

- Assessoria de Auditoria Interna - AUD;

- Assessoria de Comunicação Social - ACS;

- Assessoria Jurídica - AJU;

- Assessoria Parlamentar - ASP;

- Departamento de Administração de Materiais e Serviços - DRM;

- Departamento de Administração Financeira - DAF;

- Departamento de Gestão de Pessoas - DGP;

- Departamento de Tecnologia da Informação - DTI;

- Gabinete do Diretor-Presidente - GRP;

- Secretaria de Gestão e Estratégia - SGE;

- Superintendência de Pesquisa e Desenvolvimento - SPD.

Os Centros de Pesquisa da Embrapa são classificados em Unidades de serviço, Unidades de pesquisa de produtos, Unidades de pesquisa de temas básicos e Unidades de pesquisa agroflorestal ou agropecuária nas ecorregiões brasileiras.

As Unidades de serviço são:

- Embrapa Café, em Brasília - DF;

- Embrapa Informação Tecnológica, em Brasília - DF;

- Embrapa Transferência de Tecnologia, em Brasília - DF. 
As Unidades de pesquisa de produtos são:

- Embrapa Algodão, em Campina Grande - PB;

- Embrapa Arroz e Feijão, em Santo Antonio de Goiás - GO;

- Embrapa Caprinos, em Sobral - CE;

- Embrapa Florestas, em Colombo - PR;

- Embrapa Gado de Corte, em Campo Grande - MS;

- Embrapa Gado de Leite, em Juiz de Fora - MG;

- Embrapa Hortaliças, em Brasília - DF;

- Embrapa Mandioca e Fruticultura, em Cruz da Almas - BA;

- Embrapa Milho e Sorgo, em Sete Lagoas - MG;

- Embrapa Pecuária Sudeste, em São Carlos - SP;

- Embrapa Pecuária Sul, em Bagé - RS;

- Embrapa Soja, em Londrina - PR;

- Embrapa Suínos e Aves, em Concórdia - SC;

- Embrapa Trigo, em Passo Fundo - RS;

- Embrapa Uva e Vinho, em Bento Gonçalves - RS. 
As Unidades de pesquisa de temas básicos são:

- Embrapa Agrobiologia, em Seropédica - RJ;

- Embrapa Agroindústria de Alimentos, no Rio de Janeiro - RJ;

- Embrapa Agroindústria Tropical, em Fortaleza - CE;

- Embrapa Informática Agropecuária, em Campinas - SP;

- Embrapa Instrumentação Agropecuária, em São Carlos - SP;

- Embrapa Meio Ambiente, em Jaguariúna - SP;

- Embrapa Monitoramento por Satélite, em Campinas - SP;

- Embrapa Recursos Genéticos e Biotecnologia, em Brasília - DF;

- Embrapa Solos, no Rio de Janeiro - RJ.

As Unidades de pesquisa agroflorestal ou agropecuária nas ecorregiões brasileiras:

- Embrapa Acre, em Rio Branco - AC;

- Embrapa Agropecuária Oeste, em Dourados - MS;

- Embrapa Amapá, em Macapá - AP;

- Embrapa Amazônia Ocidental, em Manaus - AM;

- Embrapa Amazônia Oriental, em Belém - PA; 
- Embrapa Cerrados, em Planaltina - DF;

- Embrapa Clima Temperado, em Pelotas - RS;

- Embrapa Meio Norte, em Teresina - PI;

- Embrapa Pantanal, em Corumbá - MS;

- Embrapa Rondônia, em Porto Velho - RO;

- Embrapa Roraima, em Boa Vista - RR;

- Embrapa Semi-Árido, em Petrolina - PE;

- Embrapa Tabuleiros Costeiros, em Aracaju - SE.

\subsubsection{A Embrapa Instrumentação Agropecuária}

A Embrapa Instrumentação Agropecuária, um dos quarenta Centros de Pesquisa da Embrapa, está localizada na cidade de São Carlos, estado de São Paulo.

Criada em 1984, por um grupo de pesquisadores físicos, engenheiros eletrônicos e físico-químicos, inicialmente recebeu o nome de Unidade de Apoio à Pesquisa e Desenvolvimento de Instrumentação Agropecuária (UAPDIA).

As relevantes contribuições científicas e tecnológicas fizeram com que a unidade de pesquisa, que era transitória, passasse a ser, em 1990, unidade permanente com o nome de Núcleo de Pesquisa e Desenvolvimento de Instrumentação Agropecuária (NPDIA). Em $1^{\circ}$ de maio de 1993, foi instituído o Centro Nacional de Pesquisa e Desenvolvimento de Instrumentação Agropecuária - CNPDIA (EMPRESA 
BRASILEIRA DE PESQUISA AGROPECUÁRIA, 2001). Sua assinatura síntese é Embrapa Instrumentação Agropecuária.

A missão da Embrapa Instrumentação Agropecuária é viabilizar soluções para o desenvolvimento sustentável do agronegócio, por meio da geração, adaptação e transferência de conhecimentos e tecnologias em instrumentação ${ }^{2}$ para o benefício da sociedade (EMPRESA BRASILEIRA DE PESQUISA AGROPECUÁRIA, 2000).

\section{Compete à Embrapa Instrumentação Agropecuária:}

- Gerar, desenvolver e adaptar metodologias avançadas e tecnologias para medir, controlar, avaliar, processar, transferir e armazenar parâmetros físicos, químicos e biológicos essenciais para a sustentabilidade do agronegócio brasileiro;

- Gerar, desenvolver e utilizar metodologias avançadas e tecnologias em instrumentação para viabilizar produtos e processos do agronegócio;

- Sistematizar, disponibilizar e difundir conhecimentos em instrumentação para o agronegócio;

- Capacitar e assessorar as unidades da Embrapa na área de instrumentação para o agronegócio, incluindo atividades de manutenção com engenharia em equipamentos laboratoriais.

Com 56 funcionários, dos quais 20 são pesquisadores, a Embrapa Instrumentação Agropecuária atua em oito linhas de pesquisa, sendo: agricultura de precisão, meio ambiente, biotecnologia, automação de processos, novos materiais, agricultura e agroindústria familiar, qualidade de produtos e matérias-primas, manutenção de equipamentos laboratoriais. Aeromodelo para Reconhecimento da Cobertura de Solo,

${ }^{2}$ Entende-se por instrumentação o desenvolvimento de métodos, conceitos e projetos, construções manutenção com engenharia, utilização de sistemas, sensores a atuadores para: observações, medição e controle, comunicação e processamento de sinais e imagens. 
Clorador, Fossa Séptica Biodigestora e Língua Eletrônica são alguns dos produtos gerados pela unidade. Os principais produtos desenvolvidos e oferecidos pela Embrapa Instrumentação Agropecuária estão apresentados no Apêndice 1 deste trabalho.

A estrutura organizacional da Embrapa Instrumentação Agropecuária está sob a coordenação de uma Chefia Geral e organizada em duas Chefias Adjuntas - de Pesquisa e Desenvolvimento e de Administração - e uma Gerência de Comunicação e Negócios (Figura 10).

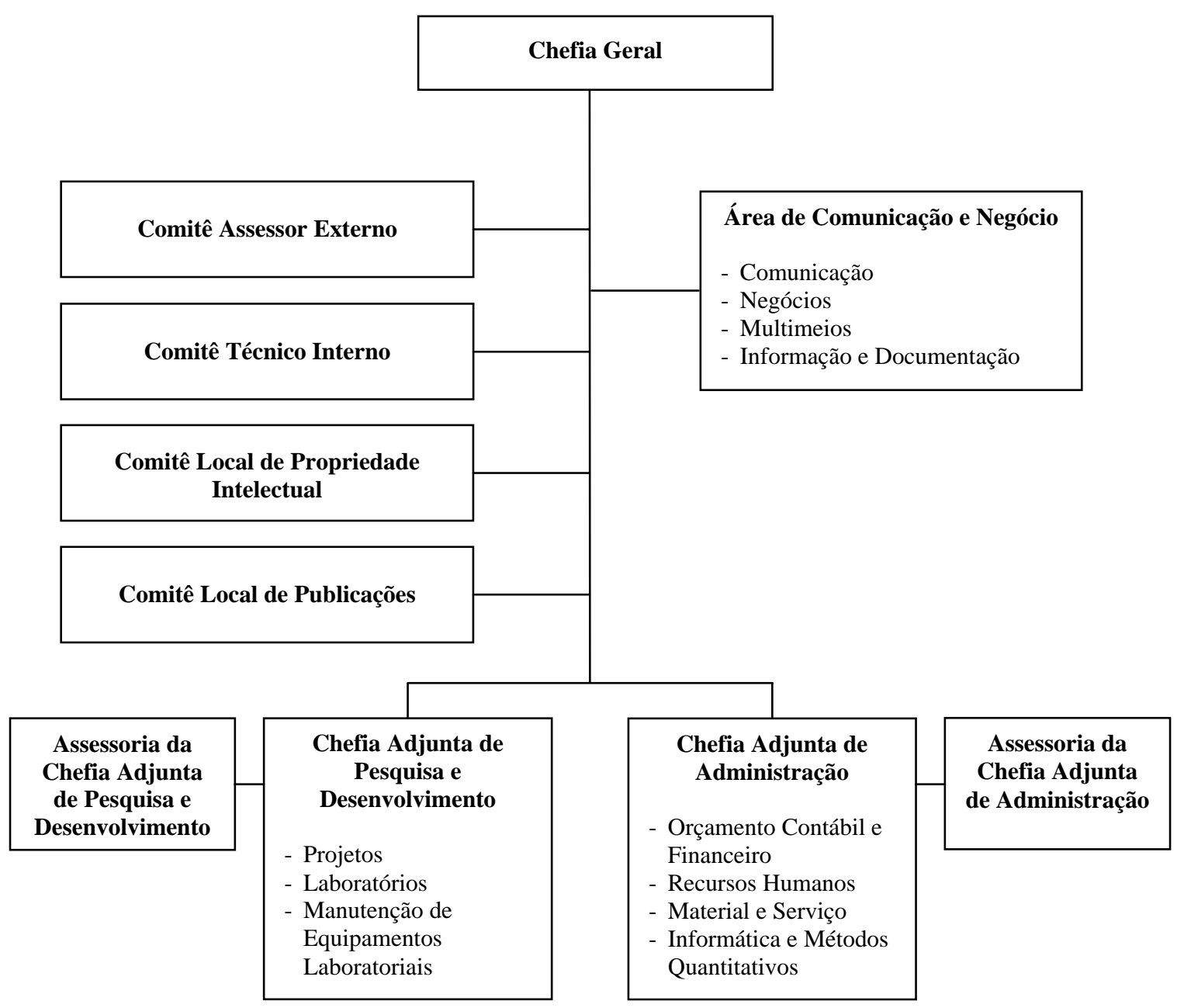

Figura 10 - Estrutura organizacional da Embrapa Instrumentação Agropecuária 


\subsection{A evolução do planejamento estratégico na Embrapa}

A Embrapa foi fundada em um momento de reestruturação institucional que estava vinculada a um conjunto de medidas políticas e econômicas empreendidas pelo Estado, cujo propósito era acelerar o processo de desenvolvimento do país e de inserí-lo no cenário econômico internacional da década de 1970. Sua missão era coordenar o sistema nacional de inovação tecnológica agropecuária e de promover a gestão de programas de pesquisa que fossem capazes de provocar a modernização da agricultura brasileira (BRITO, 2000).

Nos primeiros anos de sua existência, a Embrapa investiu maciçamente em programas de capacitação de recursos humanos, fortalecendo a infra-estrutura física de pesquisa e definindo seu modelo institucional com centros nacionais por produtos (EMPRESA BRASILEIRA DE PESQUISA AGROPECUÁRIA, 1998).

A partir da década de 80, em decorrência das mudanças no ambiente político, econômico e social do país, as organizações passaram a visualizar a ciência e tecnologia como um fator determinante na busca de um diferencial competitivo em um cenário globalizado e dinâmico.

Diante desse ambiente, as organizações públicas se viram obrigadas a institucionalizar práticas de gestão que fossem capazes de promover ganhos de eficiência e eficácia no atendimento do interesse público, para se manterem competitivas e sustentáveis nesse novo mercado. Para Brito (2000), essa necessidade passou a exercer uma espécie de pressão coercitiva sobre as organizações públicas de pesquisa, principalmente no que se refere ao controle de resultados e, ao privilegiar a racionalidade empresarial, imprimiu novas exigências às organizações públicas de pesquisa, forçando-as a promoverem uma reorientação estratégica.

Como forma de acompanhar as mudanças desse novo ambiente e com o objetivo de modernizar sua gerência e definir rumos e direcionamentos institucionais de médio e longo prazos, a Embrapa, desde 1988, vem exercitando o planejamento 
estratégico por meio da elaboração e implementação de seus Planos Diretores, para a Empresa (PDE) e suas Unidades Descentralizadas (PDU’s).

O Quadro 11 apresenta os cenários organizacionais pelos quais a Embrapa passou, destacando-se a mudança ocorrida na empresa a partir de 1988, quando iniciou-se o exercício de planejamento estratégico como conseqüência das grandes mudanças ocorridas no ambiente ao qual a empresa estava inserida.

\section{Quadro 11 - Cenários organizacionais da Embrapa}

\begin{tabular}{|c|c|}
\hline PERÍODO & CENÁRIOS ORGANIZACIONAIS DA EMBRAPA \\
\hline Década de 70 & $\begin{array}{l}\text { - formação e consolidação da Empresa; } \\
\text { - criação e desenvolvimento de seus recursos humanos; } \\
\text { - disponibilidade de recursos financeiros para o desenvolvimento de } \\
\text { projetos. }\end{array}$ \\
\hline 1988 a 1992 & $\begin{array}{l}\text { - elaboração e implementação do I Plano Diretor; } \\
\text { - modernização da gestão empresarial; } \\
\text { - aplicação do planejamento estratégico; } \\
\text { - foco no resultado. }\end{array}$ \\
\hline 1994 a 1998 & $\begin{array}{l}\text { - elaboração e implantação do II Plano Diretor; } \\
\text { - } \text { análise de cenários globais; } \\
\text { - redefinição da missão e visão da Empresa; } \\
\text { - implantação de projetos estratégicos para estruturar e dar consistência ao } \\
\text { modelo de gestão; } \\
\text { - definição de uma política global da Empresa composta por: pesquisa e } \\
\text { desenvolvimento, negócios e comunicação empresarial. }\end{array}$ \\
\hline 1999 a 2003 & $\begin{array}{l}\text { • elaboração e implantação do III Plano Diretor; } \\
\text { • foco no cliente; } \\
\text { • estrutura por processos/projetos. }\end{array}$ \\
\hline
\end{tabular}

Fonte: adaptado de Ubeda (2003) 
“O objetivo central do processo de reorientação estratégica foi fazer crescer, no interior da cultura organizacional, uma nova compreensão sobre a sustentabilidade institucional que não fosse mais baseada em elos políticos frágeis, mas em uma maior interação entre a organização e seus clientes, beneficiários ou usuários” (BRITO, 2000, p. 106, relato de entrevista de ex-presidente).

“No planejamento estratégico, as organizações buscaram os recursos gerenciais para apoiar o processo de revisão e ajustes. [...] A boa elaboração do planejamento estratégico depende fundamentalmente de uma clara visão de possíveis estados futuros devendo estes, serem baseados em tendências e eventos potenciais” (EMPRESA BRASILEIRA DE PESQUISA AGROPECUÁRIA, 2003b, p.7).

Segundo Brito (2000), outro fator determinante que leva a essa reorientação estratégica das empresas públicas é a tendência de o Estado reduzir progressivamente a sua participação no financiamento das atividades de pesquisa e priorizar investimentos na formação de recursos humanos e infra-estrutura. Dessa maneira, as empresas públicas necessitam buscar novas fontes de recursos para o custeio de suas pesquisas, além daquelas oriundas do governo. Para obter esses recursos, as organizações públicas de pesquisa passam a concorrer entre si e, até mesmo, com empresas do setor privado, sendo necessária a criação de estratégias que consolidem parcerias com a iniciativa privada e agências de fomento, na busca de financiamentos para o desenvolvimento das pesquisas.

"No que se refere ao auto-financiamento como regra de sobrevivência, as empresas públicas de pesquisas, incluindo a Embrapa, estão tentando desenvolver parcerias com a iniciativa privada, que no Brasil não tem tradição em investir em pesquisa agropecuária. Dessa forma, as organizações públicas de pesquisa agropecuária estão enfrentando o dilema da escassez de recursos públicos e da baixa participação do setor privado" (BRITO, 2000, p. 101).

Para Ribeiro, Vasconcelos e Ramalho (2002), as mudanças de natureza institucional e fiscal que estão ocorrendo na sociedade brasileira e, em particular, nos governos Federal e estaduais, têm imposto restrições e controles dos orçamentos cada vez maiores nas organizações públicas em geral, reforçando a necessidade de se 
incrementar a cooperação entre diferentes esferas do setor público e entre essas e entes privados, com vistas a maximizar a capacidade de atuação das instituições públicas.

Portanto, em seu III Plano Diretor (PDE), com vigência de 1999 a 2003, a Embrapa define sua missão, objetivos e estratégias, com base no contexto atual por que passa o Brasil e na situação de mudanças de uma civilização globalizada, cuja gestão não é simples.

Para que a Embrapa possa se tornar uma empresa de referência, o III Plano Diretor postula, entre outras diretrizes estratégicas, "ser uma empresa focada no cliente e estruturada por processo". Processos esses que utilizam os recursos da organização para oferecer resultados objetivos aos seus clientes.

“A Embrapa considera como cliente todo indivíduo, grupo ou entidade, pública ou privada, cujo sucesso em suas atividades dependa dos produtos e serviços, de natureza econômica ou social, oferecido pela empresa e seus parceiros” (EMPRESA BRASILEIRA DE PESQUISA AGROPECUÁRIA, 1998).

Para implementar as propostas do III Plano Diretor a Empresa iniciou um processo de reestruturação e incentivo às Unidades Descentralizadas a adotarem a estrutura por processos em substituição à estrutura funcional predominante na Empresa. No modelo proposto foram definidas, na estrutura da Unidade, apenas as chefias geral e adjuntas e as áreas de comunicação e negócios. No nível das supervisões foram definidos os processos de trabalho, em substituição aos setores e áreas tradicionais. Esse processo vem sendo implantado de forma democrática, onde é possibilitado às UD’s, por um período, adotar uma estrutura semi-flexível.

A Figura 11 apresenta o modelo de gestão corporativo de forma geral, desenvolvido pela Embrapa. 


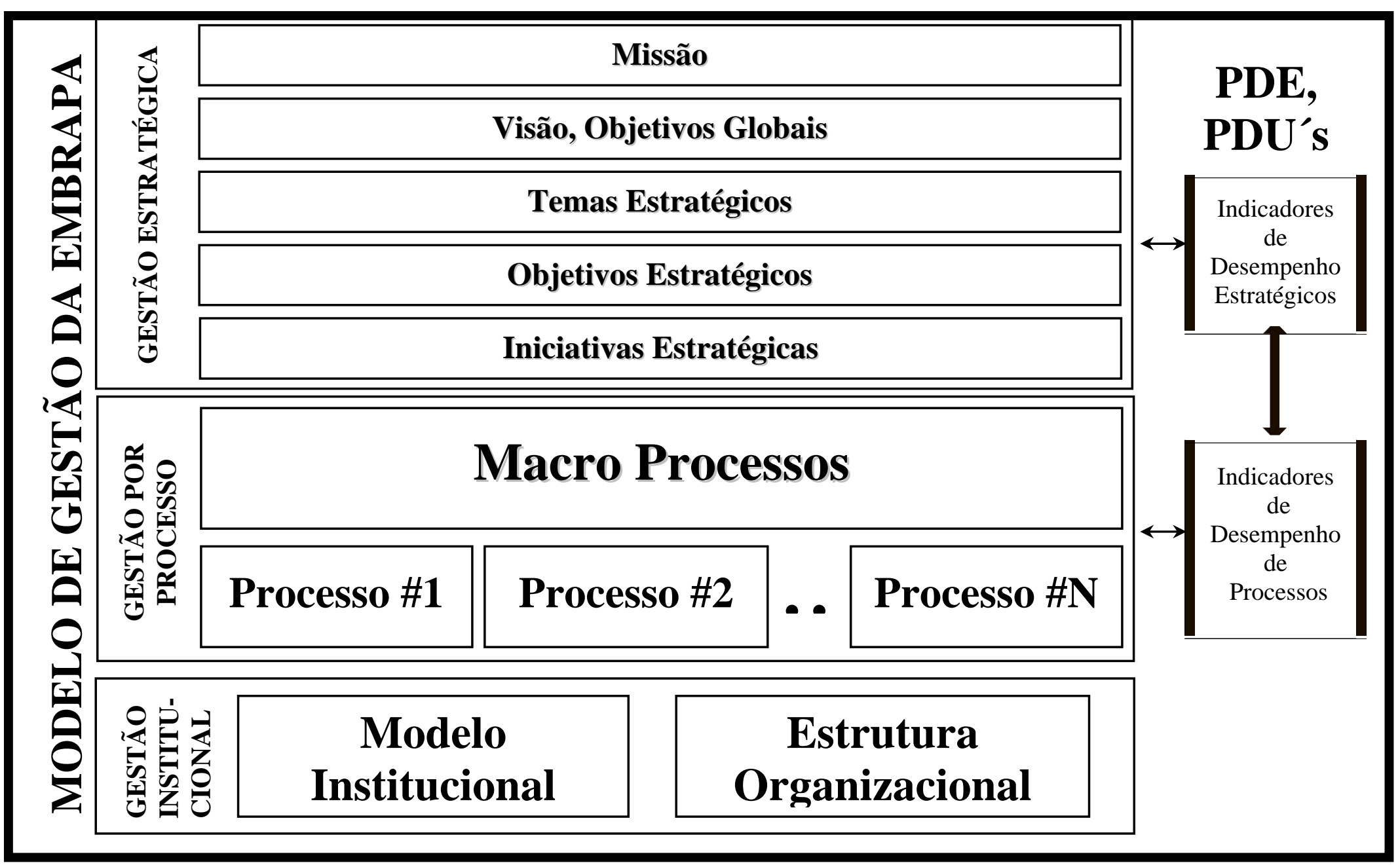

Figura 11 - Modelo de gestão corporativo da Embrapa 


\subsubsection{O planejamento estratégico na Embrapa Instrumentação Agropecuária}

Com a preocupação de adequar-se às mudanças ambientais que acontecem no país e no mundo, e seguindo as diretrizes apresentadas pela evolução do planejamento estratégico na Embrapa, a Embrapa Instrumentação Agropecuária vem desenvolvendo, a partir de 1993, o exercício do planejamento estratégico com a apresentação e implantação de seu I Plano Diretor.

Em 2000, a Embrapa Instrumentação Agropecuária reavaliou seu I Plano Diretor, novamente em consonância com o III Plano Diretor da Embrapa, levando em consideração cenários internos e externos, demandas de clientes e usuários e, principalmente, sempre considerando a importância da Ciência e Tecnologia para o desenvolvimento sustentável e competitivo.

Em conseqüência dessa reavaliação a Embrapa Instrumentação Agropecuária desenvolveu e implementou seu II Plano Diretor, que explicita sua missão de viabilizar soluções para o desenvolvimento sustentável do agronegócio, por meio da geração, adaptação e transferência de conhecimento e tecnologias em instrumentação para o benefício da sociedade.

Verifica-se, intrinsecamente, a preocupação com a satisfação do cliente refletida na preocupação com o desenvolvimento de tecnologias focadas em necessidades dos diversos segmentos do agronegócio. Objetivando o atendimento dessas necessidades, a Embrapa Instrumentação Agropecuária exercita, constantemente, o aprimoramento de seu processo de modernização organizacional, promovendo maior interação entre as diversas áreas e o planejamento em todos os níveis.

Na busca dessa moderna organização, orientada para a excelência, a Embrapa Instrumentação Agropecuária elegeu cinco projetos estratégicos: gestão estratégica, núcleos temáticos, levantamento de demandas e avaliação de impactos, comunicação e transferência de tecnologia, infraestrutura. 
No projeto de gestão estratégica, por meio de seus objetivos, é claramente demonstrada a preocupação da empresa com sua gestão, focada nos clientes e em resultados (EMPRESA BRASILEIRA DE PESQUIS AGROPECUÁRIA, 2000):

- Promover a gestão por processos e implementar o Modelo de Gestão Estratégica (MGE);

- Fundamentar, de forma sistêmica, os princípios da qualidade total, com foco no cliente e avaliação de resultados;

- Explorar e disponibilizar, otimizadamente, os recursos da internet nas diferentes áreas do Centro: técnico-científica, apoios técnico e administrativo e área gerencial, ampliando o uso de canal de satélite da Embrapa;

- Manter rede de computadores com níveis necessários de qualidade, definindo estratégias para a contínua evolução do sistema interno de informática, incluindo contratação de serviços especializados e consultorias;

- Criar mecanismos de qualificação e atualização de funcionários e parceiros.

Verificou-se, ao longo desse processo de evolução do planejamento apresentado pela Embrapa e suas unidades, a necessidade de instrumentos de gestão para operacionalizar essas estratégias formuladas no PDE e PDU’s.

Para a implementação desse planejamento foi criado o Modelo de Gestão Estratégica - MGE, adaptado à realidade da Embrapa (EMPRESA BRASILEIRA DE PESQUISA AGROPECUÁRIA, 2002). 


\subsection{O Modelo de Gestão Estratégica da Embrapa - MGE}

O modelo de gestão de $\mathrm{P} \& \mathrm{D}$ pressupõe a construção de uma orientação para o mercado, na busca pela excelência e foco no cliente, em que a geração do conhecimento científico e tecnológico passa a incorporar a lógica da pesquisa por demanda (BRITO, 2000).

“O processo de planejamento estratégico da Embrapa, mesmo estabelecendo uma direção para a empresa, mostrava-se deficiente na implantação das ações estratégicas, isto é, daquelas ações que efetivamente conduziam a empresa ao estado futuro desejado, explicitado na missão, visão e objetivos globais constantes dos planos estratégicos” (FRESNEDA, 2002).

Diante dessa situação, a Embrapa institucionalizou um instrumento de gestão que traduziu as estratégias propostas em seus planos diretores em ações estratégicas a serem implantadas para a efetivação de seus planos diretores.

Para a implementação desse planejamento foi criado o Modelo de Gestão Estratégica -MGE, desenvolvido com base no Balanced Scorecard (BSC) e adaptado à realidade da Embrapa.

Para Fresneda (2002), o MGE permite aos executivos e colaboradores, o aprendizado do processo de melhoria das estratégias por meio do exercício permanente da execução das estratégias e do feedback dos resultados alcançados.

Como resultado da aplicação dessa metodologia em um projeto piloto desenvolvido em uma unidade da empresa no período de 1997 a 1999, foi gerado um Modelo de Gestão Estratégica (MGE) operacional e gerenciável em nível corporativo para direcionamento do Plano Diretor da Embrapa (PDE). O desenvolvimento do modelo contou com a participação de um grupo de técnicos tanto das Unidades Centrais como das Unidades Descentralizadas. 
O Modelo de Gestão Corporativa procura focalizar os esforços com base nos objetivos estratégicos para os quais ela deve dirigir sua atenção e recursos, estabelecendo indicadores de desempenho, monitorando e realinhando o andamento da sua implementação, permitindo, ainda, o vínculo entre as metas institucionais e as individuais (Figura 12).

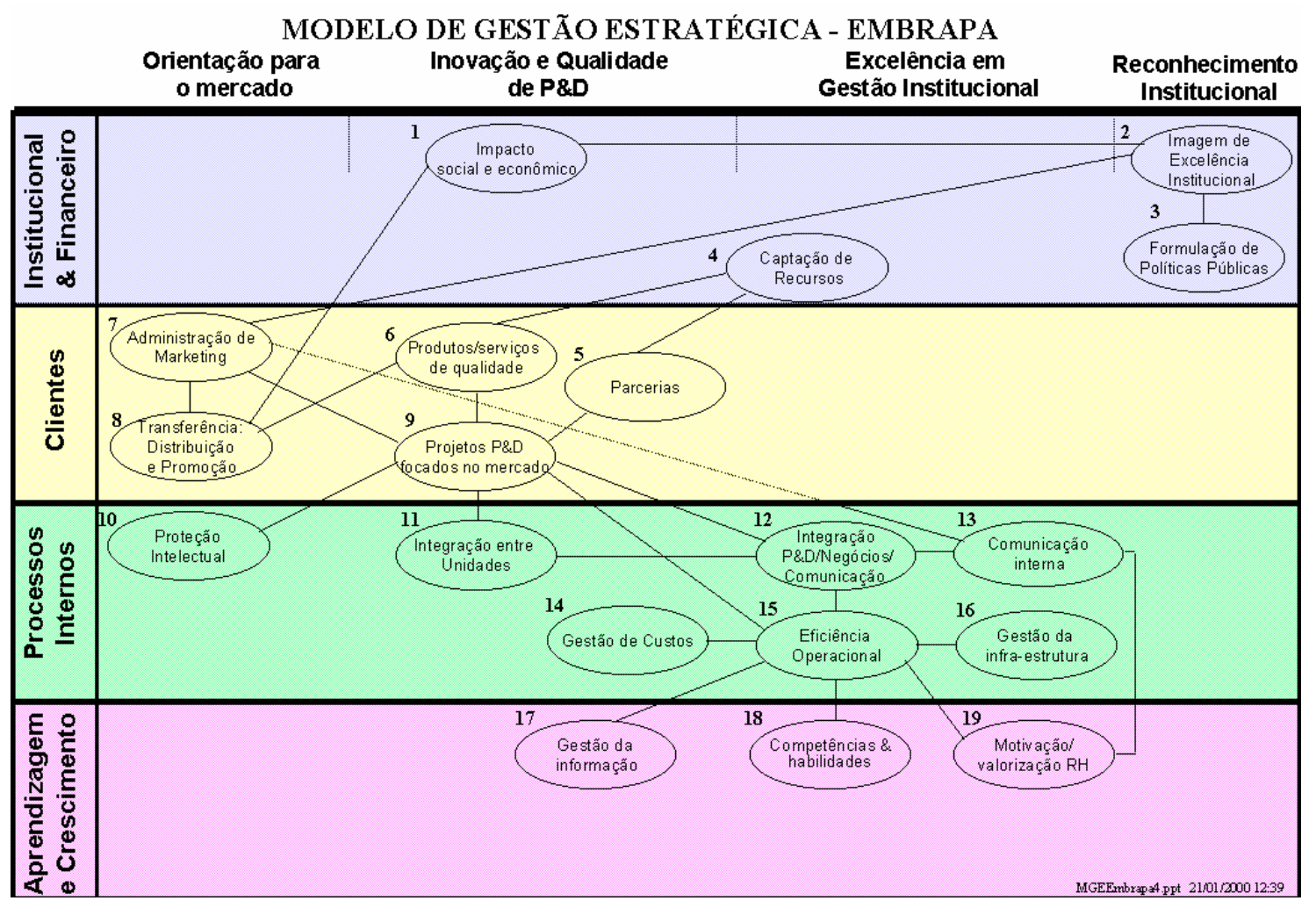

Fonte: EMPRESA BRASILEIRA DE PESQUISA AGROPECUÁRIA (2000, p. 14-15).

Figura 12 - Modelo de Gestão Estratégica Corporativo da Embrapa

Os principais objetivos do MGE são:

- operacionalizar a implantação e apoiar a gestão dos planos estratégicos, quais sejam: Plano Diretor da Embrapa (PDE) e das Unidades (PDU), onde estão explicitadas a Missão, as Diretrizes e as Metas de cada uma das Unidades da empresa; 
- atuar como agente integrador dos vários instrumentos de gestão (Planos Anuais de Trabalho - PAT, Sistema Embrapa de Planejamento - SEP, Sistema de Informações Gerenciais - SIGER, Sistema de Avaliação de Unidades - SAU e Sistema de Planejamento, Acompanhamento e Avaliação de Desempenho do Trabalho SAAD/RH) implantados na empresa como principais instrumentos da mudança organizacional;

- apoiar o processo de transformação organizacional da empresa.

Estruturado sobre as quatro perspectivas adaptadas de Kaplan e Norton (1997) - institucional e financeira, clientes, processos internos e aprendizagem e crescimento - o MGE diagrama uma matriz dividida também em quatro Temas Estratégicos, alinhados à missão e à visão estabelecidas no PDE :

- orientação para o mercado com ações de P\&D que deverão tornar disponíveis produtos e serviços de qualidade, baseados em demandas identificadas no mercado com vistas à busca da constante melhoria do nível de vida da população, diminuição dos desequilíbrios sociais e equilíbrio entre a produção e o ambiente;

- inovação e qualidade de P\&D que consiste na geração e adaptação de conhecimentos e tecnologia visando oferecer produtos e serviços de qualidade, originais e adaptados para os diversos segmentos do mercado por meio de prospecção científica e tecnológica, integração interdisciplinar e interistitucional, utilização de métodos e procedimentos adequados e uso eficiente e eficaz de recurso;

- excelência em gestão institucional, buscando a satisfação dos seus clientes internos e externos direcionada para a sua atividade-fim por meio de uma estrutura leve, flexível, ágil e descentralizada, integrada horizontalmente pela adoção da gestão por processos, com definição clara de objetivos e metas e delegação de responsabilidades e avaliação de resultados, pessoal capacitado, desenvolvido e motivado, mediante uma política de incentivos direcionada para o alto desempenho (produtividade, eficácia e efetividade). 
- reconhecimento institucional, resultado da percepção e da posição alcançada pela instituição junto à sociedade em razão das soluções e benefícios viabilizados para a clientela, a comunidade e o país, assim como, da qualidade e relevância do trabalho desenvolvido.

Uma vez formada a matriz, os temas estratégicos foram decompostos em 19 Objetivos Estratégicos (OE), associados às perspectivas de gestão:

OE 1 - Incrementar o impacto social, econômico e ampliar a sustentabilidade ambiental dos produtos e serviços da Embrapa;

OE 2 - Aprimorar a imagem de excelência institucional, com ênfase na Pesquisa e Desenvolvimento;

OE 3 - Incrementar a contribuição na formulação de políticas públicas para o agronegócio e C\&T;

OE 4 - Ampliar a captação de recursos financeiros privilegiando fontes externas ao Tesouro Nacional;

OE 5 - Incrementar as parcerias com organizações nacionais e internacionais;

OE 6 - Gerar e adaptar produtos e serviços de qualidade;

OE 7 - Implantar e manter a administração de marketing eficiente com vistas ao aumento da competitividade da Empresa;

OE 8 - Ampliar e melhorar a capacidade para transferência, distribuição estratégica e promoção de produtos e serviços;

OE 9 - Desenvolver projetos de P\&D focados no mercado;

OE 10 - Aperfeiçoar e internalizar a gestão de proteção da propriedade intelectual; 
OE 11 - Incrementar e manter a integração e articulação entre as unidades da Embrapa;

OE 12 - Promover a integração entre as ações de P\&D, de Negócios Tecnológicos e de Comunicação Empresarial;

OE 13 - Melhorar a comunicação interna;

OE 14 - Implantar, exercer e manter a gestão de custos para valoração dos produtos e serviços;

OE 15 - Aumentar a efetividade dos processos de P\&D, gerenciais e administrativos;

OE 16 - Implantar a gestão estratégica da infra-estrutura;

OE 17 - Implementar a gestão da informação para apoiar as atividades técnico-científicas, administrativas e gerenciais;

OE 18 - Desenvolver e incorporar competências e habilidades para atender às necessidades estratégicas da Embrapa;

OE 19 - Elevar a motivação e a assistência dos recursos humanos, valorizando a eficiência e a criatividade.

Para cada OE são definidos seus gerentes que, em conjunto com as chefias de cada Unidade e demais supervisores, definem um Plano de Ação Estratégico (PAE) para cada objetivo, que são incluídos no Plano Anual de Trabalho (PAT).

O Plano Anual de Trabalho (PAT), planejado pela unidade com vistas no MGE, é desmembrado em planos de trabalho individuais onde cada empregado terá suas atividades especificadas e, por meio do Sistema de Acompanhamento e Avaliação de Desempenho (SAAD), serão monitorados e corrigidos quaisquer desvios com relação à meta pré-estabelecida. Verifica-se aqui, a importância das pessoas, representadas por meio do SAAD, como um elemento de extrema importância no processo de gestão 
estratégica da Embrapa uma vez que, por meio de suas atividades diárias previstas no SAAD, em consonância com o MGE, refletem diretamente na efetividade do planejamento estratégico - PDE (SENTANIN, 2003).

A Figura 13 apresenta o processo de gestão estratégica na Embrapa, desde seu planejamento estratégico propriamente dito, refletido no PDE até a importância das pessoas nesse processo (SAAD), incluindo também o feedback das avaliações de unidades e pessoas (Sistema de Avaliação de Unidades - SAU e Sistema de Premiação - SAPRE), visando às atualizações dos próprios MGEs, do PDE e dos PDUs (EMPRESA BRASILEIRA DE PESQUISA AGROPECUÁRIA, 2000).

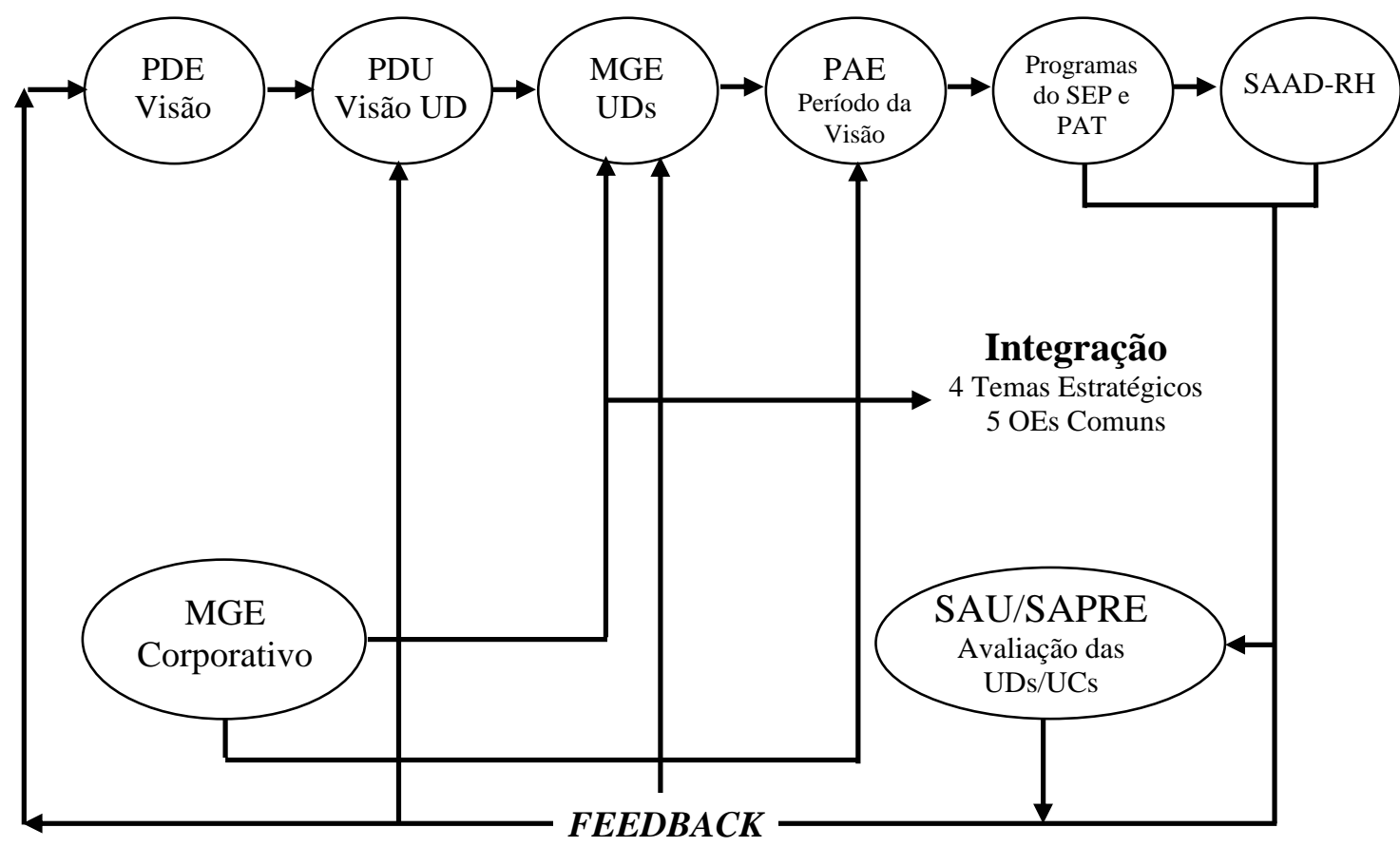

Legenda:

PDE - Plano Diretor da Embrapa;

SEP - Sistema Embrapa de Planejamento;

PDU - Plano Diretor da Unidade;

PAT - Plano Anual de Trabalho;

UD - Unidade;

MGE - Modelo de Gestão Estratégica;

SAAD - Sistema de Acompanhamento e Avaliação de Desempenho;

PAE - Plano de Ação Estratégico;

SAU - Sistema de Avaliação de Unidade;

SAPRE - Sistema de Premiação.

Fonte: EMPRESA BRASILEIRA DE PESQUISA AGROPECUÁRIA (2000, p. 14-15).

Figura 13 - Processo de Gestão Estratégica na Embrapa 


\subsubsection{O Modelo de Gestão Estratégica da Embrapa Instrumentação Agropecuária}

Uma vez finalizado e testado o Modelo de Gestão Estratégica Corporativo, em uma das unidades, eleita como unidade piloto, o modelo foi apresentado às demais unidades da Embrapa, de 1999 a 2001.

Para divulgar e apresentar esse novo modelo, a Embrapa sede, realizou um treinamento a dois funcionários designados por cada unidade, denominados “facilitadores”, que teriam a incumbência de receber o treinamento sobre o novo modelo e disseminar em suas unidades de origem, auxiliando na criação dos modelos de gestão estratégicas de cada unidade.

Tendo como base o Modelo de Gestão Estratégica Corporativo, seu Plano Diretor e, contando com o auxílio dos “facilitadores”, cada unidade designou uma comissão, especialmente criada, para a elaboração de seu Modelo de Gestão Estratégica com seus objetivos estratégicos.

Os objetivos estratégicos presentes no MGE corporativo - impacto social, econômico e ambiental, administração de marketing e melhoria de processo de transferência e distribuição, projetos de $\mathrm{P} \& \mathrm{D}$ focados no mercado e produtos e serviços de qualidade (OE 1, 6, 7, 8 e 9) foram comuns a toda Embrapa, pois estão relacionados às prioridades identificadas no PDE, imprescindíveis para que a Empresa alcance os resultados esperados, e deveriam constar em todos os modelos das unidades.

Baseada nessas diretrizes, a Embrapa Instrumentação Agropecuária elaborou seu Modelo de Gestão Estratégica (Figura 14), estabelecendo 12 objetivos estratégicos, assim definidos:

OE 1 - Impacto social, econômico e ambiental;

OE 2 - Imagem de excelência institucional;

OE 3 - Captação de recursos; 
OE 4 - Administração de marketing, comercialização e proteção intelectual;

OE 5 - Produtos/serviços de qualidade;

OE 6 - Parcerias internas e externas;

OE 7 - Projetos de P\&D focados no mercado;

OE 8 - Integração - P\&D/Negócios/Comunicação;

OE 9 - Comunicação interna;

OE 10 - Implantação da gestão por processos;

OE 11 - Gestão da informação;

OE 12 - Motivação, qualidade de vida e competência.

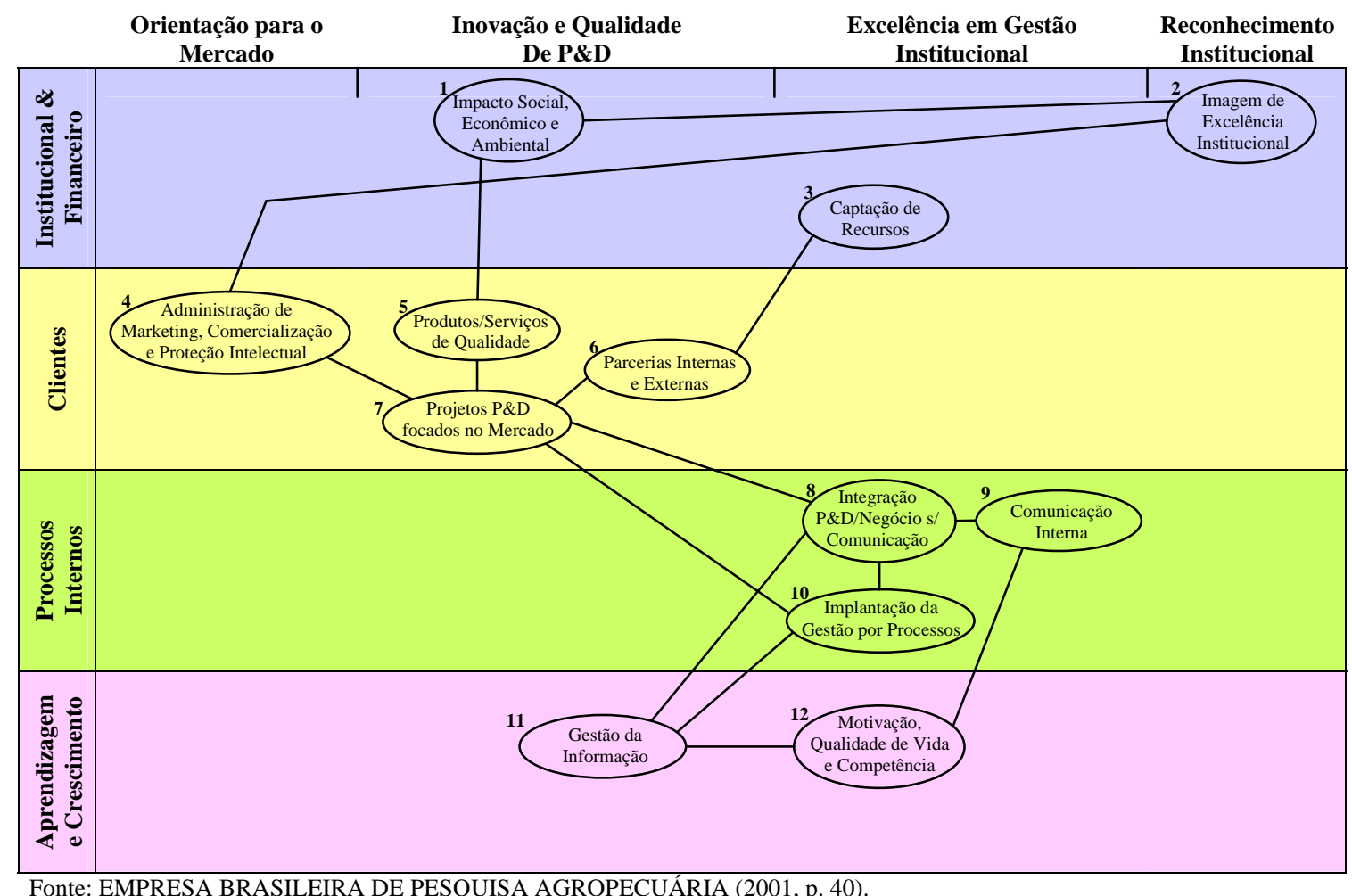

Figura 14 - Modelo de Gestão Estratégica da Embrapa Instrumentação Agropecuária 


\subsection{Gestão por processos na Embrapa}

Verifica-se, em seus Planos Diretores, a preocupação da Embrapa com as constantes e importantes mudanças ocorridas no cenário mundial. Na busca pela excelência, também em termos organizacionais, a Embrapa explicita em seu III Plano Diretor a importância de promover uma gestão baseada em princípio de qualidade, sendo focada no cliente, estruturada por processo e embasada na avaliação de resultados, acoplada a sistemas de recompensa.

Para efetivar essa perspectiva apresentada em seu III Plano Diretor a Embrapa implementou ações voltadas a implantação de uma gestão por processos, ou seja, um modelo organizacional que privilegia a flexibilidade, o fluxo de informações, a busca de parcerias, a confiança e o compartilhamento de informações e uma maior integração entre as atividades e equipes fortalecendo a comunicação.

A estratégia em aumentar a efetividade dos processos de pesquisa e desenvolvimento (P\&D), gerenciais e administrativos tem por objetivo a consciência dos empregados na execução de suas atividades com a visão de processo, o trabalho em equipe com rapidez, qualidade e produtividade, a redução do desperdício e a adoção dos princípios de gestão pela qualidade total (EMPRESA BRASILEIRA DE PESQUISA AGROPECUARIA, 2002a).

Demonstrando a intenção da Embrapa em relação à implementação da gestão por processo, o objetivo estratégico 15 do MGE corporativo estabelece a gestão voltada para o aumento da efetividade dos processos de $\mathrm{P} \& \mathrm{D}$, gerenciais $\mathrm{e}$ administrativos. O objetivo estratégico busca o bom desempenho de tais processos, por meio da execução dos mesmos em equipe com rapidez, qualidade, produtividade, redução de despesas objetivando a plena satisfação dos clientes com os resultados alcançados.

Nessa linha, o MGE propõe que o trabalho não ocorra mais em setores isolados, dentro de departamentos, coordenações, supervisões etc., mas por processo, ou 
seja, procurando reagrupar atividades, tornando-as mais integradas, sistêmicas e interdependentes.

Para que ocorra essa mudança organizacional de uma visão funcional para uma visão de processos, a Embrapa apresenta alguns pré-requisitos:

- envolvimento do pessoal, de modo que todos trabalhem com o mesmo objetivo, em termos de lealdade e compromisso;

- comunicação a todos os funcionários, inclusive altos executivos, de forma gerenciada, planejada, para que não haja más interpretações dos objetivos propostos;

- trabalho em equipe;

- capacitação e empowerment da equipe;

- $\quad$ inter-relação das equipes de processos;

- sistema de informação eficiente, possibilitando a gerência da execução dos processos.

Em termos institucionais, o compromisso com essa mudança organizacional para processos também está presente no Sistema de Avaliação de Unidades - SAU, onde todas as unidades estabelecem anualmente, como meta qualitativa a melhoria de três processos, e também na Premiação Nacional de Equipes, que possui uma categoria específica para premiar as cinco melhores equipes que se destacaram na análise e melhoria de processos.

Com isso a empresa busca criar mecanismos efetivos de incentivo para a implantação da Gestão por Processos nas Unidades, buscando o compartilhamento de experiências entre as unidades, a racionalização de recursos e esforços no sentido das equipes de Análise e Melhoria de Processos concentrarem-se em processos essenciais e de maior relevância para a Embrapa e suas unidades. 
Nesse sentido, a empresa configurou uma modelo de gestão por processos que apresenta uma arquitetura geral, em que destacam os três componentes principais para sua efetivação - componentes estratégicos; componentes de análise e melhoria de processos e componentes de suporte (Figura 15).

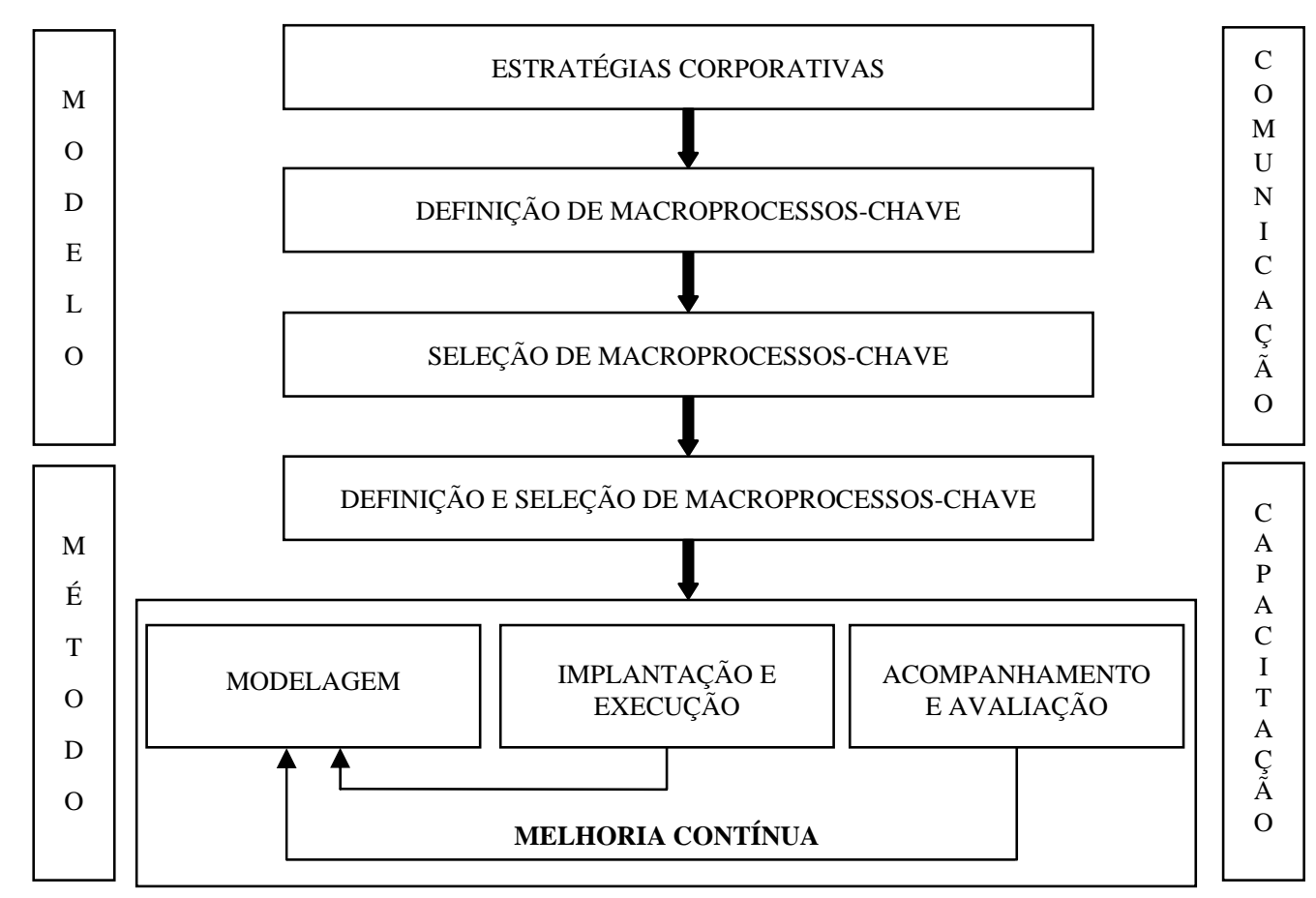

TECNOLOGIA - WORKFLOW /ERP

Fonte: EMPRESA BRASILEIRA DE PESQUISA AGROPECUÁRIA (2002a, p. 32).

Figura 15 - Gestão por processos da Embrapa: arquitetura geral

Outro mecanismo utilizado pela empresa, na busca de compartilhamento e integração entre as unidades, foi a criação e disponibilização na intranet, de um banco de dados, denominado "banco de boas práticas”, onde todos os processos analisados e melhorados pelas unidades da Embrapa, são apresentados, sucintamente, a todos os empregados e gerentes da empresa, de modo que possa haver um benchmarking entre as unidades na busca de se evitar retrabalho em processos já estudados. Por exemplo, analisar e melhorar um processo que já tenha sido melhorado por outra unidade. Nessa situação, inicia-se o processo de melhoria a partir do que já foi proposto e implementado pela unidade anterior e, a partir desse estágio, buscar uma melhoria incremental. 
Nesse “banco de boas práticas” são cadastrados processos de acordo com uma classificação pré-estabelecida:

- Aguardando Parceria, processos de interesse geral da empresa, em que a Unidade deseja modelar ou promover melhorias em futuro próximo, mas em função da abrangência e complexidade, considera mais viável a realização do trabalho de análise e melhoria em parceria com outras Unidades;

- Em Operação, processo em uso corrente na Unidade, para o qual, em função do desempenho atual, precisam ser efetuadas análise e implementação de melhorias;

- Em Modelagem, processos analisados em que estejam sendo implementadas melhorias, incluindo a redefinição e reimplantação do fluxo de atividades;

- Implantado Manualmente, processos analisados e melhorados, que já estejam em rotina na Unidade e cujos planos de melhoria foram implementados e não demandaram ações de automação;

- Implementado Automatizado, Processos analisados e melhorados, que já estão em rotina na Unidade, cujos planos de melhoria incluíram a automação de etapas ou do processo como um todo;

- Indicadores em Operação, Processos analisados e melhorados que encontram-se na fase de implantação e monitoramento dos indicadores de desempenho, os quais possibilitarão mensurar os atributos e resultados do processo e também a comparação com os padrões de qualidade previamente definidos;

- Monitoramento da Satisfação, processos analisados e melhorados, com indicadores de desempenho implantados e monitorados, que encontram-se na fase de implantação da pesquisa sistemática de satisfação dos clientes, tanto em termos de resultados como no que se refere aos requisitos de qualidade. 
- Em Melhoria Contínua, processos sistematizados, para os quais foi realizada a análise, as melhorias foram implantadas, o sistema de indicadores de desempenho e o nível de satisfação dos clientes estão sendo monitorados e as ações de melhoria contínua estão em rotina.

Esse banco de dados foi amplamente divulgado para toda a empresa por meio de cartazes que objetivam incentivar os funcionários das unidades a exporem suas idéias e ações gerenciais que possam servir de referência para a Embrapa (Apêndice 2).

\subsubsection{Metodologia de análise e melhoria de processos na Embrapa}

Para auxiliar as unidades no exercício de melhoria dos processos, a Embrapa apresentou uma metodologia de análise e melhoria de processos (AMP). “Ao utilizar a metodologia de AMP, a equipe passa a ter uma visão mais integrada dos processos da Unidade e da Empresa. As pessoas, ao invés de trabalharem com uma lista de atribuições, passam a trabalhar com processos identificados e descritos” (EMPRESA BRASILEIRA DE PESQUISA AGROPECUÁRIA, 2002a, p.133).

Segundo a própria empresa, uma das principais vantagens dessa mudança é a disponibilidade de informações aos executores do processo, que facilitam a realização do trabalho com qualidade, uma vez que, na descrição do processo, definemse claramente objetivo, clientes, indicadores de desempenho, produtos e resultados esperados.

A metodologia de AMP apresentada pela empresa é composta por oito fases constituídas de atividades e que geram produtos específicos, conforme apresentado no Quadro 12 e detalhado a seguir. 


\section{Quadro 12 - Visão geral da metodologia de análise e melhoria de processos (AMP) na Embrapa}

\begin{tabular}{|c|c|c|}
\hline FASES & PRODUTOS & $\begin{array}{c}\text { EXECUTOR / } \\
\text { RESPONSÁVEL }\end{array}$ \\
\hline $\begin{array}{l}\text { 1. Identificação e Descrição } \\
\text { do Processo }\end{array}$ & $\begin{array}{l}\text { - Descrição do Processo } \\
\text { - Macrodiagrama }\end{array}$ & Equipe de AMP \\
\hline 2. Modelagem e Melhoria & $\begin{array}{l}\text { - Fluxogramas dos subprocessos } \\
\text { - Definição dos I.D } \\
\text { - Plano de Melhoria }\end{array}$ & Equipe de AMP \\
\hline $\begin{array}{l}\text { 3. Implantação Manual do } \\
\text { Processo Modelado e } \\
\text { Melhorado }\end{array}$ & $\begin{array}{l}\text { - Gerente do processo designado } \\
\text { - Equipe formada e treinada } \\
\text { - "Documentação” do processo disponível }\end{array}$ & $\begin{array}{l}\text { Gerente do } \\
\text { Processo }\end{array}$ \\
\hline $\begin{array}{l}\text { 4. Acompanhamento e } \\
\text { Avaliação (implementação } \\
\text { dos Indicadores de } \\
\text { Desempenho-I.D.) }\end{array}$ & $\begin{array}{l}\text { - Descrição dos I.D. } \\
\text { - Formulário(s) de Coleta dos Dados dos I.D. } \\
\text { - Demonstrativo da evolução dos I.D. } \\
\text { - Relatório de três Gerações }\end{array}$ & $\begin{array}{l}\text { Gerente do } \\
\text { Processo }\end{array}$ \\
\hline 5. Automação do Processo & - Software para automação pronto e testado & Área de Informática \\
\hline $\begin{array}{l}\text { 6. Implantação da } \\
\text { Automação do Processo }\end{array}$ & $\begin{array}{l}\text { - Treinamento da Equipe no uso do Software } \\
\text { - Software para automação implantado e } \\
\text { operacional }\end{array}$ & Área de Informática \\
\hline $\begin{array}{l}\text { 7. Monitoramento da } \\
\text { Satisfação do Cliente }\end{array}$ & $\begin{array}{l}\text { - Relatório(s) de Avaliação da Satisfação do } \\
\text { cliente }\end{array}$ & $\begin{array}{l}\text { Gerente do } \\
\text { Processo }\end{array}$ \\
\hline $\begin{array}{l}\text { 8. Elaboração do Plano de } \\
\text { Melhoria Contínua }\end{array}$ & $\begin{array}{l}\text { - Plano de Melhoria Contínua-5w2h } \\
\text { - Descrição, Macrodiagrama, Fluxogramas e } \\
\text { Indicadores revisados }\end{array}$ & Equipe de AMP \\
\hline
\end{tabular}

Fonte: EMPRESA BRASILEIRA DE PESQUISA AGROPECUÁRIA (2002a, p.138).

A fase de identificação e descrição do processo é realizada após a seleção do processo a ser analisado, sendo necessário todas as informações sobre o mesmo. Os produtos gerados por essa fase fornecem uma visão geral do processo, compreendendo:

- Descrição do processo;

- Macrodiagrama do processo.

As atividades executadas para a geração desses produtos são:

- Definição da equipe que será responsável pelo trabalho e elaboração do plano de execução; 
- Apresentação do processo para a equipe que conduzirá o trabalho, para nivelamento de informações a todos os membros do grupo sobre o processo a ser modelado;

- Elaboração da descrição do processo, compreendendo o nome do processo, objetivo, entradas, normas e procedimentos, atividade que inicia o processo, conteúdo, atividade, saídas ou produtos, clientes, fornecedores, indicadores de desempenho e equipe responsável pela execução do processo;

- Elaboração do macrodiagrama do processo, que fornece uma visão, rápida, simples e abrangente do processo, com entradas, fornecedores, saídas e clientes.

A fase de modelagem e melhoria tem por objetivo fornecer uma visão mais detalhada possível do processo, apresentando os seguintes produtos:

- Fluxograma dos subprocessos;

- Definição dos indicadores de desempenho;

- Relatório de melhoria.

São executadas as seguintes atividades nessa fase:

- Levantamento dos requisitos e necessidades dos clientes do processo;

- Elaboração do fluxograma dos subprocessos, levando-se em consideração sua situação atual para que possam ser propostas melhorias;

- Análise das atividades que agregam valor ao processo, na busca de avaliar a conveniência e impacto de eliminar atividades que não agregam valor; 
- Definição dos fatores críticos de sucesso do processo, na busca de selecionar as atividades que têm maior impacto no resultado final e impedir que sua incorreta execução gere resultados indesejáveis ou retrabalho;

- Definição dos indicadores de desempenho que servirão para monitorar o processo;

- Revisão da descrição e do macrodiagrama;

- Validação do modelo geral;

- Elaboração do Relatório de Melhoria.

A fase de implantação manual do processo modelado e melhorado é a fase de validação e ajuste do modelo definido. Os principais produtos gerados nessa fase são:

- Gerente do processo designado;

- Equipe formada e treinada;

• “Documentação” do processo disponível para a equipe.

As principais atividades que compõem essa fase são:

- Seleção e designação do gerente do processo, preferencialmente com aptidões para a gerência de pessoas e habilidade para se relacionar com equipes multidisciplinares;

- Constituição e treinamento da equipe que executará o processo;

- Disponibilização da “documentação” do processo para conhecimento de toda a equipe. 


\section{A fase de acompanhamento e avaliação (implementação dos}

indicadores de desempenho) compreende o monitoramento do processo, por meio de seus indicadores de desempenho, que foram estabelecidos e deverão ser medidos periodicamente visando verificar possíveis desvios que interferem em seu desempenho.

Os produtos gerados nessa fase são:

- Descrição dos indicadores de desempenho - I.D.;

- Formulário de coleta dos dados dos I.D.;

- Demonstrativo da evolução dos I.D.;

- Relatório de Três Gerações.

As atividades relacionadas a essa fase são as seguintes:

- Descrição dos indicadores de desempenho, identificando os dados necessários para a sua obtenção, os pontos de coleta, os "meios de coleta” e a periodicidade;

- Monitoramento dos indicadores de desempenho;

- Elaboração do relatório de “Três Gerações”, que permite a visualização do que foi planejado, do executado e proposição de novas ações para o plano estabelecido.

A fase de automação do processo produz melhorias expressivas, com a utilização da tecnologia da informação, tendo como produto o software para automação pronto e testado. 
A fase de implantação da automação do processo consiste na integração do software para automação com a equipe do processo, tendo como principais produtos gerados:

- Treinamento da equipe do processo no uso do software;

- Software para automação implantado e operacional.

A fase de monitoramento da satisfação do cliente avalia a satisfação do cliente em relação ao processo e pode ser realizada sistematicamente através dos Indicadores de Desempenho (contínua e rotineira) ou realizando pesquisas periódicas de Satisfação dos Clientes (periódica e pontual). O produto gerado nessa fase é o Relatório de Avaliação da Satisfação do Cliente.

A fase de elaboração do plano de melhoria contínua deve ser executada periodicamente durante o processo de modo a rever o ciclo do processo, completando com isso o ciclo de melhoria contínua da metodologia. Os principais produtos gerados nessa fase são:

- Plano de Melhoria Contínua - 5W2H;

- Descrição, macrodiagrama, fluxograma e indicadores de desempenho revisados.

As principais atividades executadas nessa fase são:

- Definição da equipe e elaboração de plano de melhoria;

- Identificação dos problemas do processo que está sendo analisado, utilizando a técnica de Brainstorming ou Brainwriting, e sua priorização, utilizando a técnica de 
Votação Múltipla ou Matriz GUT (matriz de gravidade, urgência e tendência dos objetos selecionados);

- Identificação e priorização das causas que estão provocando esse problema, conduzindo-se uma sessão de Brainstorming ou Brainwriting. As causas do problema devem ser classificadas e organizadas no Diagrama de Causa e Efeito (espinha de peixe) e priorizadas utilizando-se a técnica de Votação Múltipla ou Matriz GUT;

- Identificação e priorização das soluções para as causas identificadas, tendo-se sempre em mente o problema que está sendo analisado;

- Elaboração do plano de ação utilizando-se a Planilha 5W2H (What - O que deve ser feito? Who - Quem fará? Where - Onde será implementada a solução? When Quando será implementada? Why - Por que essa atividade é necessária? How - Como será realizada essa atividade? How much - Quanto custa para executá-la?);

- Atualização da descrição, macrodiagrama, fluxograma e indicadores de desempenho do processo.

\subsubsection{A gestão por processos na Embrapa Instrumentação Agropecuária}

Após várias discussões internas e elaboração de uma apostila inicial sobre gestão por processos, em setembro de 2001, a empresa iniciou uma divulgação de forma mais efetiva a todas as suas unidades, culminando com um treinamento corporativo a dois funcionários de cada unidade de pesquisa da empresa, escolhidos pela Chefia Geral. A empresa enfatizou às Chefias a importância da indicação de funcionários que realmente estivessem engajados e comprometidos com essa nova visão de negócio, uma vez que caberiam a eles a tarefa de exercitar a aplicação da gestão de processo em suas respectivas unidades, atuando como "multiplicadores” da metodologia aos demais empregados. 
Demonstrando o envolvimento da empresa com esse novo modelo de gestão proposto, além do treinamento realizado pelos seus funcionários sobre a metodologia de gestão por processos, a Embrapa incluiu, também, no Sistema de Avaliação de Unidades (SAU), a obrigatoriedade de cada unidade propôr a análise e melhoria de três processos anuais.

A Embrapa Instrumentação Agropecuária, em consonância com a proposta apresentada pela empresa, vem aplicando a metodologia de análise e melhoria de processos, constituindo anualmente, comissões encarregadas de realizar a análise e melhoria de seus processos propostos. O Quadro 13 apresenta os processos selecionados pela unidade para análise e proposta de melhoria.

\section{Quadro 13 - Processos analisados e melhorados na Embrapa Instrumentação Agropecuária}

\begin{tabular}{|c|c|}
\hline Ano & Processo \\
\hline 2000 & $\begin{array}{l}\text { - Atendimento ao cliente externo; } \\
\text { - Atendimento aos clientes da biblioteca; } \\
\text { - Manutenção de equipamentos laboratoriais. }\end{array}$ \\
\hline 2001 & $\begin{array}{l}\text { - Registro de metas realizadas; } \\
\text { - Uso do laboratório de Preparação de Amostras. }\end{array}$ \\
\hline 2002 & $\begin{array}{l}\text { - Atendimento ao cliente; } \\
\text { - Comunicação interna; } \\
\text { - Prestação de serviços; } \\
\text { - Registro de metas. }\end{array}$ \\
\hline $2003 / 2004$ & $\begin{array}{l}\text { - Acervo documental - organização e tratamento da informação; } \\
\text { - Ações para otimização de custos; } \\
\text { - Captação de recursos via projetos de P\&D. }\end{array}$ \\
\hline
\end{tabular}


No final de 2003 foram analisados e receberam propostas para melhoria no ano de 2004 os seguintes processos:

- Acervo documental - organização e tratamento da informação, com a finalidade de preservar o acervo e melhorar as condições de armazenamento e busca da informação;

- Ações de otimização de custos, com a finalidade de desenvolver ações para o envolvimento de todos os agentes, visando à otimização dos custos da Unidade;

- Captação de recursos via projetos de $P \& D$, com a finalidade de elaboração de normas e otimização da atividade.

Para a análise e proposta de melhoria dos processos técnico-científicos e de apoio, as comissões constituídas para essa finalidade, buscam solucionar os problemas específicos a cada processo detectados por meio de sugestões e críticas recebidas, considerando-se a perspectiva do cliente, tanto interno como externo, e o foco no resultado.

\subsubsection{A visão de clientes para a Embrapa Instrumentação Agropecuária}

Considerando os clientes atuais como aqueles que precisam de seus serviços/produtos e clientes potenciais aqueles que desejam ter seus produtos ou serviços e novas tecnologias, a Embrapa Instrumentação Agropecuária classifica e segmenta seus clientes em dois grandes grupos, cujo critério de segmentação é orientado pela natureza dessa demanda, ou seja, em qual estágio de desenvolvimento de uma determinada tecnologia esses clientes se enquadram (EMPRESA BRASILEIRA DE PESQUISA AGROPECUÁRIA, 2003): 
- Tecnologias disponibilizadas, clientes que demandam produtos, serviços, tecnologias e material técnico ou de divulgação já disponibilizados pela empresa. Esse segmento é constituído por todo indivíduo, grupo ou entidade, empresário do campo, produtor ou criador, ou membro de qualquer elo da cadeia produtiva que, em algum momento de sua atividade econômica ou social, interage com a Embrapa Instrumentação Agropecuária;

- Tecnologias em fase de pesquisa e desenvolvimento, segmento constituído por pesquisadores da própria Embrapa ou de outras instituições de pesquisa públicas ou privadas, por alunos, por empresas privadas e por parceiros da Embrapa Instrumentação Agropecuária, que demandam por processos, metodologias, tecnologias, serviços ou conhecimento que estão em fase de pesquisa e desenvolvimento. São, portanto, parceiros ativos e participantes do processo de desenvolvimento de novas tecnologias e que em muitos casos trazem o problema ou a demanda por soluções que requerem a atuação da empresa.

\subsubsection{A classificação dos processos na Embrapa Instrumentação Agropecuária}

As unidades da Embrapa classificam seus processos em duas grandes categorias:

- Processos finalísticos e de desenvolvimento institucional, são aqueles relativos às atividades essenciais da empresa como P\&D, Transferência de Tecnologia e Comunicação Empresarial;

- Processos de suporte à pesquisa e de administração, são aqueles que apoiam as atividades essenciais da empresa. 
Os processos finalísticos e de desenvolvimento institucional da Embrapa Instrumentação Agropecuária compreendem uma gama de processos de Pesquisa e Desenvolvimento (P\&D) e de Transferência de Tecnologia - baseada na gestão voltada ao cliente e a obtenção de resultados - ligados diretamente aos projetos de pesquisas, que tem início na prospecção de demandas do mercado e termina na disponibilização de produtos, processos e serviços (tecnologias).

Os processos finalísticos da Embrapa Instrumentação Agropecuária, ligados diretamente à sua atividade-fim são:

- Desenvolvimento de equipamentos;

- Desenvolvimento de metodologias;

- Serviços de manutenção de equipamentos laboratoriais;

- Transferência de tecnologia;

- Solicitação de patentes.

Tais processos finalísticos foram avaliados, baseados na nova forma de gestão introduzida pela Embrapa, em 2002. Foram criados Macroprogramas, os quais induzem a pesquisa nas áreas avaliadas como de interesse da empresa para atingir sua missão e objetivos, sempre voltados, também, aos interesses da sociedade. São divididos em cinco, os macroprogramas, com características específicas quanto à estrutura de suas equipes e arranjos institucionais, orientando-se para a obtenção de resultados de impacto que levem ao cumprimento das metas técnicas da empresa, tendo cada um seus projetos, fontes de financiamento e formas de indução de projetos específicos.

Os cinco macroprogramas são: 
- Macroprograma 1 - Grandes Desafios Nacionais, compreende uma carteira de projetos de $P \& D$ de base científica elevada, de caráter transdisciplinar, multiinstitucional e estratégica, com uma estrutura de parcerias complexa, formando grandes redes de pesquisa. Os avanços tecnológicos perseguidos nesse macroprograma devem romper fronteiras e estabelecer novos paradigmas, além de contemplar a busca pela superação de desequilíbrios sociais;

- Macroprograma 2 - Competitividade e Sustentabilidade Setorial, compreende uma carteira de projetos de P\&D de caráter aplicado, estratégico ou eventualmente básico, devendo ser interdisciplinares. A estrutura, embora menos complexa que no Macroprograma 1, deve apresentar a organização de clusters, equipes interativas e redes. Os avanços esperados devem ser significativos, inovadores e subsidiar políticas públicas voltadas para o estímulo da competitividade e sustentabilidade do agronegócio e o desenvolvimento econômico e social do país;

- Macroprograma 3 - Desenvolvimento Tecnológico Incremental do Agronegócio, são projetos que apoiam o aperfeiçoamento tecnológico contínuo do agronegócio e atividades correlatas, com vistas voltadas ao atendimento de suas demandas e necessidades de curto e médio prazos. A execução deve ocorrer em arranjos simples, com pouca intensidade de aplicação de recursos. Esses projetos estão voltados para atividades de $\mathrm{P} \& \mathrm{D}$, transferência de tecnologia, organização de informação e viabilização de atividades previstas em contratos de prestação de serviços técnicos não rotineiros;

- Macroprograma 4 - Transferência de Tecnologia e Comunicação Empresarial, projetos de Transferência de Tecnologia e de Comunicação Empresarial que integram a atividade de P\&D e o mercado. Pode abrigar iniciativas de caráter aplicado, de natureza temática ou interdisciplinar, com equipes compatíveis com a complexidade do seu tema;

- Macroprograma 5 - Desenvolvimento Institucional, são projetos que tem como objetivo consolidar e atualizar os instrumentos de gestão estratégica da Embrapa (Planos Diretores, Agenda Institucional e Modelo de Gestão Estratégica Corporativo); ampliar os resultados e a efetividade organizacional; desenvolver e 
utilizar plenamente o potencial dos talentos humanos da empresa; implantar a gestão por processo na empresa e realizar ações que visem a adoção dessa forma de organização e divisão do trabalho; desenvolver a gestão do recurso informação e a gestão do conhecimento. Esse macroprograma compõe-se de projetos e processos que integram equipes multiinstitucionais e multidisciplinares, e que buscam avanços técnicos ou administrativos, radicais ou incrementais, para o estabelecimento de novos paradigmas no desenvolvimento institucional. Ele abrange, ainda, projetos e processos previstos em contratos de prestação de serviços técnicos, que caracterizam desenvolvimento institucional.

Os processos de suporte à pesquisa e de administração são os processos de apoio técnico e administrativo que fornecem suporte aos processos finalísticos, sendo desenvolvidos de acordo com procedimentos gerenciais, visando otimização de desempenho e foco no cliente e resultados.

Os processos de apoio da Embrapa Instrumentação Agropecuária são:

- Gestão de laboratórios;

- Comunicação interna;

- Compras;

- Gestão do almoxarifado;

- Controle patrimonial;

- Manutenção e conservação de bases físicas;

- Manutenção de máquinas, móveis e equipamentos;

- Controle e manutenção de veículos; 
- Controle de viagens a serviço;

- Administração orçamentária e financeira;

- Administração de recursos humanos;

- Capacitação de curta duração;

- Treinamento de pós-graduação;

- Bem-estar de recursos humanos;

- Segurança no trabalho;

- Estágio de complementação educacional;

- Gestão de contratos de serviços terceirizados;

- Gestão da informação;

- Gestão da propriedade intelectual;

- Atendimento ao cliente;

- Divulgação na mídia escrita, falada e televisiva.

\subsection{Considerações finais}

Este estudo de caso apresentou o processo de evolução da Embrapa Instrumentação Agropecuária em termos de uma empresa orientada para processos, 
como conseqüência do exercício de seu planejamento estratégico, tendo como premissa as mudanças ocorridas no ambiente em que a empresa está inserida.

A apresentação do Modelo de Gestão Estratégica da Embrapa, baseado no Balanced Scorecard, possibilitou à empresa viabilizar e operacionalizar seu planejamento estratégico, e proporcionou, também, às suas unidades, a possibilidade de alinharem seus modelos organizacionais aos modelos corporativos apresentados pela Embrapa, na busca de atendimento das demandas dos clientes e foco em resultados, inserindo-se nesse contexto, a gestão por processos, como um dos objetivos estratégicos de seu modelo de gestão.

A importância desta visão de processos proposta pela Embrapa, explicitada em seu planejamento estratégico e modelo de gestão, demonstra a sua preocupação na busca da efetividade em termos estratégicos, táticos e operacionais.

No entanto, conforme apresentado na revisão de literatura, a lacuna existente entre a avaliação da estratégia e o ambiente operacional, há muito tem criado dificuldades na implantação dessas estratégias e na efetividade de processos como, por exemplo, o planejamento estratégico.

Ao longo desta pesquisa, ficou patente ter havido uma grande evolução quanto ao engajamento, tanto em nível gerencial como dos próprios funcionários envolvidos nos processos. A metodologia de análise e melhoria de processos implementada pela Embrapa tem auxiliado, também, as unidades no exercício da aprendizagem com relação a essa nova proposta de estrutura organizacional.

A proposta apresentada pela própria Embrapa, quando disponibilizou a todas as unidades o "banco de boas práticas" demonstra sua preocupação com o ambiente organizacional, na busca de maior integração entre as diversas unidades da empresa.

Especificamente, a unidade pesquisada, Embrapa Instrumentação Agropecuária, também vêm passando por um momento de transição e aprendizado 
organizacional, com a proposta de implantação desse novo modelo de estrutura organizacional.

Dentro deste processo de evolução organizacional apresentado pela Embrapa Instrumentação Agropecuária, com o auxílio da metodologia de análise e melhoria de processo, houve uma grande evolução para a implantação desta nova proposta de estrutura organizacional, observado no avanço dos processos em suas diversas fases. Os processos escolhidos para serem analisados, de forma efetiva, cumpriam apenas a fase de planejamento e implementação; ficavam para segundo plano, as fases de acompanhamento e reavaliação dos processos. No entanto, principalmente neste último ano, a fase de acompanhamento dos processos propostos tem recebido maior atenção, com reuniões periódicas da comissão de análise e melhoria de processos para avaliação das ações tomadas no decorrer do período e para proposição de novas ações.

Vale destacar que, a proatividade na proposição desta fase de acompanhamento é demandada pela gerência, que demonstra, uma vez mais, a importância da conscientização dos altos executivos para a efetividade do processo.

Do ponto de vista dos clientes, a Embrapa Instrumentação Agropecuária também demonstra sua preocupação em detectar quais são seus reais clientes e, principalmente, quais estratégias utilizar para transformar seus processos de pesquisa em resultados que contribuam e atendam às necessidades por eles apresentadas.

No processo denominado “captação de recursos via projetos de P\&D”, por exemplo, a grande preocupação da comissão encarregada de analisar e propor melhorias, reside no fato de a unidade diagnosticar quais são realmente seus clientes (iniciativa privada, agências de fomento, instituições de pesquisa) com o objetivo de alinhar seus processos de modo a ampliar a capacidade de captação, a otimização dos recursos humanos e materiais e o direcionamento das ações de captação de recursos baseados em um plano estratégico de gerenciamento do processo.

Outro ponto importante destacado por essa comissão é a necessidade de compor arranjos internos entre as áreas de P\&D, Negócios e Administrativa, com o 
objetivo de prospectar demandas e otimizar o fluxo operacional das ações de pesquisa. Essa integração entre as áreas é de fundamental importância para que os processos estejam alinhados em prol da efetividade organizacional e na busca da vantagem competitiva para, assim, sobreviver nesse novo ambiente de competição.

Um exemplo, relatado por um funcionário que caracteriza a importância desse tipo de gestão e demonstra a evolução para uma gestão por processos, foi pontual, mas considerada importante, em uma reunião programada de alta gerência, da qual participaram as diversas áreas envolvidas em um processo de aquisição de materiais a serem usados para determinado projeto. A partir dessa reunião, o funcionário em questão, retornou às suas atividades com conhecimento do motivo pela qual estaria realizando seu trabalho o que, segundo ele, contribuiu para desempenhar tais atividades com maior motivação e rapidez.

Comparados os resultados desta pesquisa com os estágios evolutivos de uma empresa em direção à organização por processos, apresentados por Gonçalves (2000b), verifica-se que, de acordo com algumas características, a Embrapa Instrumentação Agropecuária, enquadra-se no estágio “B”:

- seus processos e subprocessos foram identificados, porém o foco do esforço ainda está centrado nas funções: conforme observação de alguns funcionários, apesar de as propostas de mudança e implementação de algumas melhorias, a unidade, de modo geral, não absorveu a proposta de processos; para a maioria deles, não está claro o funcionamento desse novo modelo. Neste sentido, o trabalho continua centrado em suas atividades funcionais, sem a visão de processo;

- seus processos são enquadrados na estrutura funcional e empregam formas de trabalho antigas: apesar da mudança no organograma da unidade e a eliminação de níveis organizacionais, as principais áreas funcionais continuaram a existir.

A alteração no organograma da unidade, com a eliminação de alguns cargos de nível gerencial, na linha de supervisão funcional, gerou forte resistência 
desses gerentes em relação à nova estrutura organizacional. Essas resistências foram caracterizadas por dois motivos: primeiro a perda de autonomia e poder sobre suas atividades e seus subordinados, o que corrobora os estudos de Hammer e Stanton (1999). O segundo motivo que contribuiu para a resistência gerencial funcional, foi o financeiro, pois com a extinção de algumas funções gerenciais, esse supervisores também perderam seus cargos comissionados, o que gerou desconforto e insatisfação. Como relatado por esses supervisores, o problema apresentado nessa mudança, foi o fato de, na visão deles, continuarem a desempenhar as mesmas atividades desenvolvidas anteriormente à mudança.

Isto mostra que a transição de uma empresa estruturada por funções para uma organizações por processos envolve aprendizado organizacional e muitas dificuldades em termos de resistências por parte de funcionários e gerentes, o que demonstra a necessidade de a mudança ocorrer gradativamente e com muito esforço por parte da organização.

\section{Quadro 14 - Estágio evolutivo da Embrapa Instrumentação Agropecuária rumo à organização por processos}

\begin{tabular}{|c|c|c|}
\hline & $\begin{array}{c}\text { Estágio B } \\
\text { (Gonçalves, 2000b) }\end{array}$ & $\begin{array}{c}\text { Embrapa Instrumentação } \\
\text { Agropecuária }\end{array}$ \\
\hline Situação atual & $\begin{array}{lcc}\text { - } \begin{array}{l}\text { Processos, } \\
\text { subsubprocessos identificados. }\end{array} & \mathrm{e}\end{array}$ & $\begin{array}{l}\text {-Processos identificados dentro das } \\
\text { funções. }\end{array}$ \\
\hline Comentários & $\begin{array}{l}\text { - O foco do esforço ainda está nas } \\
\text { funções; } \\
\text { - Os processos são enquadrados na } \\
\text { estrutura funcional; } \\
\text { - A abordagem é ampla demais; } \\
\text { - A forma de trabalho é provavelmente } \\
\text { ainda antiga. }\end{array}$ & $\begin{array}{l}\text {-Há uma grande preocupação da unidade } \\
\text { com os processos, mas esses continuam } \\
\text { enquadrados dentro dos setores } \\
\text { funcionais; } \\
\text { •O trabalho continua centrado em suas } \\
\text { atividades funcionais; } \\
\text { •A visão de processos não está clara para } \\
\text { muitos funcionários da empresa; } \\
\text {-A metodologia de análise e melhoria de } \\
\text { processos apresentada pela empresa está } \\
\text { sendo utilizada pela unidade, como } \\
\text { exercício para alguns processos eleitos } \\
\text { para análise e melhoria. }\end{array}$ \\
\hline
\end{tabular}




\section{CONCLUSÕES}

Este trabalho buscou avaliar como a Embrapa está se estruturando para atender aos novos desafios que se apresentam nesse novo contexto de mudança, os quais forçam as organizações a reavaliarem e readequarem seus modelos de gestão e suas estruturas organizacionais para poderem se manter competitivas.

Este capítulo final confronta a teoria apresentada nos Capítulos 2 e 3 com o estudo de caso apresentado no Capítulo 4. O capítulo é finalizado com abrangência deste estudo e sugere alguns direcionamentos para trabalhos futuros.

\subsection{Confrontação entre teoria e prática}

De modo geral, o futuro vai pertencer às empresas que conseguirem explorar o potencial de concentração em suas prioridades, das ações e dos recursos em seus processos essenciais, deixando de avaliar somente os processos de produção, e centrando esforços também nos processos gerais da empresas - administrativos, de pesquisa e de comunicação e negócios - sempre com objetivos de atendimento aos clientes. Para tanto, elas deverão decidir por um modelo de organização orientada por processos que apresente melhores resultados e avaliar, estrategicamente, quais 
providências devem ser tomadas para realizar a transição de sua atual estrutura para a estrutura desejada.

As grandes transformações pelas quais o mundo tem passado nos últimos anos, forçam as organizações a reverem seus modelos de gestão na busca da alcançarem vantagem competitiva sustentável.

Obterão vantagem competitiva sustentável as empresas que conseguirem se planejar e estruturar-se para esse processo de mudança, de forma a conseguirem implementá-lo e prosseguirem na busca de posições melhores - mesmo depois das mudanças.

No caso da Embrapa, está clara a preocupação com esse novo ambiente quando, a partir de 1988, a empresa começou a exercitar e implementar seus planos diretores, como forma de se manter competitiva.

Tanto o Plano Diretor da Embrapa (PDE) como os Planos Diretores das Unidades (PDU's) enfocam a preocupação da empresa com seu futuro e mostram que para conseguir sobreviver a esse futuro incerto, é necessária a criação de modelos organizacionais que auxiliem a Embrapa a obter vantagem competitiva sustentável, por meio da otimização de processos para maior agilidade e rapidez no desenvolvimento das atividades-meios, para que essas interfiram o menos possível nos resultados a serem alcançados em sua atividade-fim.

Para que isso ocorra, é necessário que todas as pessoas envolvidas nos processos tenham entendimento claro e exato que qualquer processo começa e termina em um cliente e, principalmente, que saibam quem são, realmente, seus clientes. No caso da Embrapa, com a criação do Modelo de Gestão Estratégica (MGE), como forma de operacionalizar sua estratégia, e a proposta de implementação da gestão por processos, a empresa buscou internalizar sua proposta de mudança e enfatizar, a seus funcionários e gerentes, a importância do cliente nesse novo cenário.

No entanto, para que esta internalização tenha os resultados desejados, é de grande importância a conscientização das pessoas sobre o trabalho em equipe e, 
principalmente, que saibam qual seu papel dentro do processo neste novo modelo organizacional, bem como o motivo pelo qual está desempenhando tal atividade dentro de uma visão maior. Para que isso efetivamente ocorra, é necessária uma mudança cultural dos funcionários envolvidos nos processos de modo para deixarem de ver suas atividades isoladamente e passarem a percebê-las como parte integrante de um todo dentro da organização.

Outro fator importante para essa mudança organizacional na Embrapa ser efetiva e conseguir os resultados planejados é a conscientização da alta gerência - não somente em nível corporativo mas, principalmente, em termos de unidades - quanto à importância dessas mudanças, pois não basta os funcionários estarem motivados, é necessária, também, essa proatividade em termos gerenciais. Um exemplo dessa participação mais efetiva da alta gerência nesse processo, pode ser verificado por meio da participação desses gerentes nas comissões de análise e melhoria de processos da Embrapa Instrumentação Agropecuária.

Conforme diagnosticado ao longo desta pesquisa, desde a implantação da metodologia de análise e melhoria de processos, houve evolução organizacional em termos desta metodologia. A proposta da empresa, que cada unidade proponha, anualmente, a análise e melhoria de três processos, contribui significativamente para esse aprendizado. A fase de acompanhamento dos processos planejados e implementados tem recebido grande atenção, principalmente por parte da alta gerência, o que demonstra sua preocupação com a efetividade desta proposta e, principalmente, a importância dos altos executivos para o processo de aprendizagem e evolução em termos de processo.

No entanto, com base nesta pesquisa, verificou-se na empresa em estudo, que a adoção da estrutura por processos não está efetivada de forma clara, identificandose, ainda, a presença de características de uma organização funcional, principalmente, no que diz respeito à perspectiva de clientes não evidenciando a visão geral do processo.

Verifica-se a necessidade de a empresa reforçar, em seus funcionários e executivos, uma visão mais ampla do seu trabalho, como premissa básica para uma gestão orientada para processos, de modo a efetivar uma interação maior entre os 
envolvidos de cada etapa do processo e, até mesmo, que extrapole os limites da sua atual unidade organizacional.

Percebe-se, com a redução de níveis hierárquicos e funções gerenciais apresentadas pela empresa, que, financeiramente, talvez a empresa tenha atingido seus objetivos, porém, as ações implementadas não correspondem ao modelo de estrutura por processos, mas sim ao da estrutura funcional.

Apenas com sua reestruturação, a Embrapa Instrumentação Agropecuária não conseguiu consolidar uma visão de processos. Apesar da constante preocupação da unidade com seus processos, constata-se que, apesar de serem escolhidos com base em seus aspectos estratégicos, eles são avaliados pontualmente, caracterizando uma gestão de processos e não uma gestão por processos.

Mendes e Guimarães (2002) enfatizam que a lacuna na condução do processo de reestruturação das unidades de pesquisa da Embrapa parece estar relacionada aos aspectos comportamentais. O caminho pode estar na implementação de ações que visem à criação de um ambiente receptivo a mudanças, a redução de possíveis resistências e a busca de maior comprometimento das pessoas com o processo.

Os resultados obtidos nesta pesquisa mostram que a Embrapa Instrumentação Agropecuária, apesar de apresentar vários indicativos de mudança de estrutura organizacional para modelos mais flexíveis, ainda não institucionalizou a gestão por processos, possuindo características do modelo funcional infundidas em sua cultura organizacional.

Para Gulledge e Sommer (2002), não se pode manter uma estrutura de gerenciamento de comando e controle hierárquico e esperar que o gerenciamento de processo seja efetivo. Eles relatam que os órgãos públicos adotam os conceitos de gerenciamento de processos mas não mudam sua estrutura organizacional, o que, em experiências do setor privado mostram que aumenta a probabilidade de insucesso.

No entanto, por outro lado, esses indicativos de gestão por processos - integração das áreas, flexibilidade organizacional - estão sendo inseridos, 
de forma cada vez para incisiva, na unidade, sendo percebido, principalmente, nas reuniões das comissões de análise e melhoria dos processos.

Esses resultados demonstram que a empresa passa por uma fase de transição caracterizando um aprendizado para todos os envolvidos e, principalmente, que as resistências apresentadas a esse novo modelo de gestão proposto estão sendo reduzidas por conseqüência da internalização dos conceitos e do maior conhecimento por parte dos executivos e funcionários, sobre a metodologia proposta pela empresa.

Fica claro que a adoção da gestão por processos não se faz apenas com a mudança de estrutura; é necessário que as pessoas envolvidas estejam preparadas para adotar novos comportamentos em relação às novas práticas da organização, de modo que essas pessoas possam entender realmente qual é seu papel dentro da organização e, principalmente, que saibam para que, por que e para quem estão desempenhando tais atividades.

Como apresentado pela própria empresa, uma gestão participativa genuína requer cooperação, compartilhamento de informações e confiança para delegar, dando autonomia à equipe para atingir metas. “Como resposta, as pessoas tomam posse dos desafios e dos processos dos quais participam, tomam decisões, inovam e dão à organização um clima organizacional saudável” (EMPRESA BRASILEIRA DE PESQUISA AGROPECUÁRIA, 2002a, p.18).

Assim, com base no estudo do modelo organizacional da Embrapa, verificou-se que ainda há necessidade de a Embrapa investir em estratégias que efetivamente resultem na adoção da gestão por processo, como alternativa de modelo de gestão mais adequado a ambientes altamente competitivos e mutáveis.

Conforme apresentado por Gonçalves (1998), o grande desafio das organizações, além de identificar as mudanças, é se ajustar às variações que ocorrem com freqüência e simultaneidade. Nesse sentido é importante destacar que cada pessoa dentro da organização e, até mesmo cada organização, reage de forma diferente em relação às mudanças, sendo de grande importância o planejamento das mudanças de forma mais adequada, que contemple os anseios e expectativas de todos os atores da mudança. 


\section{Quadro 15 - Análise e perspectivas para a Embrapa Instrumentação Agropecuária rumo à organização por processos}

\section{Principais características e perspectivas da Embrapa com relação à gestão por processos}

- Preocupação clara da Embrapa com novo ambiente competitivo, com a implementação de seus planos diretores, a partir de 1988;

- Internalização da proposta de mudança com a criação do Modelo de Gestão Estratégica (MGE);

- Redução das resistências apresentadas a esse novo modelo de gestão proposto por conseqüência da internalização dos conceitos e do maior conhecimento por parte dos executivos e funcionários, sobre a metodologia proposta pela empresa;

- Atenção dada à fase de acompanhamento dos processos planejados e implementados;

- Importância do cliente nesse novo cenário;

- Importância da conscientização das pessoas sobre o trabalho em equipe e de seu papel nesse novo modelo organizacional;

- Mudança cultural dos funcionários envolvidos nos processos de modo a não mais verem suas atividades isoladamente mas como parte integrante de um todo dentro da organização;

- Maior interação entre os envolvidos de cada etapa do processo e, até mesmo que extrapole os limites da sua atual unidade organizacional;

- Conscientização da alta gerência quanto à importância dessas mudanças;

- Adoção da estrutura por processos, na Embrapa Instrumentação Agropecuária, não está efetivada de forma clara, conforme proposta pela empresa e apresentada pela teoria, identificando-se muitas características de uma organização funcional;

- Necessidade da Embrapa investir em estratégias que resultem efetivamente na adoção da gestão por processo, como uma alternativa de modelo de gestão mais adequada a ambientes altamente competitivos e mutáveis.

\subsection{Abrangência deste estudo}

Este trabalho procurou avaliar, de modo geral, como a Embrapa está se estruturando para enfrentar as mudanças ocorridas no ambiente competitivo em que está inserida. 
Especificamente, avaliou como a Embrapa Instrumentação Agropecuária, uma de suas unidades de pesquisa está vivenciando essa transição de cenários internos e externos.

Este trabalho estudou apenas uma das unidades da empresa, com suas características específicas. Ampliar o leque de unidades estudadas, deverá constribuir para a melhor avaliação de como essas unidades também estão enfrentando a transição. Seria importante, inclusive, buscar informações quanto às unidades centrais da empresa, com características diferentes das enfrentadas pelas unidades de pesquisa, que contribuiriam muito para a melhoria dos estudos.

\subsection{Sugestões para trabalhos futuros}

Esta dissertação teve a proposta apenas de abordar parte de um assunto muito vasto, que oferece diversas oportunidades para novos estudos nessa área.

Em continuidade a esta linha de pesquisa, futuros trabalhos poderão auxiliar no desenvolvimento de alternativas e soluções para equacionar os problemas enfrentados pelas organizações quanto às mudanças organizacionais, no que diz respeito à estrutura orientada para processos.

Trabalhos futuros poderão orientar-se para alguns pontos a serem desenvolvidos:

- qual a importância da tecnologia da informação nesse novo modelo de organização;

- aprofundar estudos relacionados a sistemas de recompensa a serem desenvolvidos de forma a se adequarem a estrutura orientada para processos;

- estudar e propor ferramentas de modelagem de processos que sirvam de apoio à metodologia de análise e melhoria de processos proposta pela Embrapa; 
- analisar, de forma mais aprofundada, como as organizações públicas se diferenciam das organizações privadas, por exemplo, em relação à visão de clientes;

- realizar revisão de literatura no sentido de buscar modelos de gestão alternativos que possam servir de modelo para implementação de mudanças;

- desenvolver métodos de pesquisa que embasem a identificação dos estágios evolutivos de uma organização orientada para processos.

\subsection{Considerações finais}

Esta dissertação apresentou como a gestão por processos está sendo inserida em uma empresa de pesquisa e desenvolvimento, como um dos objetivos estratégicos de seu modelo de gestão estratégica.

Por meio do aprofundamento de uma revisão bibliográfica inerente ao tema e confrontação com o estudo de caso realizado na Embrapa, este trabalho avaliou a transição da empresa de uma estrutura organizacional funcional para uma proposta de gestão orientada para processos, buscando manter-se conectada com seu planejamento estratégico.

Considerando-se que, para uma organização manter-se competitiva nesse novo ambiente, tanto interno como externo, é necessário que ela reestruture seus modelos de gestão organizacional, este estudo fornece subsídios para ajustes e mesmo para planejamento dessa reestruturação que viabilize participação mais consciente, motivada e produtiva de cada indivíduo, buscando-se - com os produtos e serviços oferecidos pela organização - satisfazer às necessidades dos clientes e buscar a otimização de resultados. 


\section{REFERÊNCIAS BIBLIOGRÁFICAS}

ALMEIDA, L.G. (2002). Gestão do processo e a gestão estratégica. Rio de Janeiro: Qualitymark.

ANDRADE, A.R.de (2002). Comportamento e estratégias de organizações em tempos de mudança sob a perspectiva da tecnologia da informação. Cadernos de Pesquisas em Administração, São Paulo, v.9, n.2, p.49-58, abr.jun.

ANSOFF, I. (1988). Administração estratégica. Tradução de Mário Ribeiro da Cruz. São Paulo: Atlas.

ANSOFF, I.; DECLERCK, R.P.; HAYES, R.L. (1990). Do planejamento estratégico à administração estratégica. Tradução de Carlos Roberto Vieira de Araújo. São Paulo: Atlas.

AQUINO, A.C.B. de (2000). Sistema de apoio ao processo decisório: a gestão econômica utilizando indicadores balanceados nas decisões estratégicas e a longo prazo. 172 p. Dissertação (Mestrado) - Escola de Engenharia de São Carlos, Universidade de São Paulo, São Carlos. 2000. 
AYRES, T.C.de S. (2002). Da escola tradicional à gestão por processos: uma perspectiva. In: SIMPÓSIO DE ENGENHARIA DE PRODUÇÃO, 9., 2002, Bauru. Anais eletrônicos... Bauru: UNESP. Disponível em: <http://www.simpep.feb.unesp.br/html/anais_ix_simpep.html>. Acesso em: 5 set. 2003.

BELMIRO, T.R. et al. (2000). Corporate communications within a BPR context. Business Process Management Journal, v.6, n.4, p.286-303.

BELMIRO, T.R.; RECHE, J.R.F. (2003). O desafio de uma gestão por processos sob a ótica de uma telecom. Revista de Administração de Empresas, São Paulo, v. 38, n.3, p.260-272, jul./ago./set.

BITITCI, U.S.; MUIR, D. (1997). Business process definition: a bottom-up approach. International Journal of Operations \& Production Management, v.17, n.4, p.365-374.

BRITO, M.J.DE (2000) Mudança e cultura organizacional: a construção social de um novo modelo de gestão de P\&D na Embrapa. 261 p. Tese (Doutorado) - Faculdade de Economia, Administração e Contabilidade, Universidade de São Paulo, São Paulo, 2000.

CAKAR, F.; BITITCI, U.S.; MACBRYDE, J. (2003). A business processes approach to human resource management. Business Process Management Journal, v.9, n.2, p.190207.

CAMARGO, M.A.de; DIAS, A.T. (2003). Estratégica, administração estratégica e estratégia corporativa: Uma síntese teórica. Caderno de Pesquisas em Administração, São Paulo, v.10, n.1, jan./mar. 
CAMPOS, J.A. (1998). Cenário balanceado (balanced scorecard): painel de indicadores para a gestão estratégica dos negócios. São Paulo: Aquariana.

CASTRO, A.M.G. de; LIMA, S.M.V.; CARVALHO, J.R.P.de (1999). Planejamento de C\&T: sistemas de informação gerencial. Brasília: Embrapa-SPI/Embrapa-DPD.

CRUZ, T. (2003). Sistemas, Métodos \& Processos: administrando organizações por meio de processos de negócios. São Paulo: Atlas.

DAVENPORT, T.H. (1994). Reengenharia de processos: como inovar na empresa através da tecnologia da informação. Rio de Janeiro: Campus.

DEJOURS, C. (1995). O fator humano. Rio de Janeiro, Fundação Getúlio Vargas.

EMPRESA BRASILEIRA DE PESQUISA AGROPECUÁRIA (1998). Secretaria de Administração Estratégica. III Plano Diretor da Embrapa: realinhamento estratégico, 1999-2003. Brasília.

EMPRESA BRASILEIRA DE PESQUISA AGROPECUÁRIA (2000). Centro Nacional de Pesquisa e Desenvolvimento de Instrumentação Agropecuária. II Plano Diretor do Centro Nacional de Pesquisa e Desenvolvimento de Instrumentação Agropecuária - CNPDIA: realinhamento estratégico 2000-2003. São Carlos.

EMPRESA BRASILEIRA DE PESQUISA AGROPECUÁRIA (2000a). Secretaria da Administração Estratégica. Modelo de Gestão Estratégica. Brasília. 
EMPRESA BRASILEIRA DE PESQUISA AGROPECUÁRIA (2001). Secretaria da Administração Estratégica. Relatório de Atividades 1998-2001 Embrapa Instrumentação Agropecuária. São Carlos.

EMPRESA BRASILEIRA DE PESQUISA AGROPECUÁRIA (2002). Secretaria de Gestão Estratégica. Modelo de gestão estratégica: descrição geral. Brasília.

EMPRESA BRASILEIRA DE PESQUISA AGROPECUÁRIA (2002a). Departamento de Organização e Desenvolvimento. Gestão por processos: manual operacional. Brasília.

EMPRESA BRASILEIRA DE PESQUISA AGROPECUÁRIA (2003a). Departamento de Organização e Desenvolvimento. Relatório de Gestão da Embrapa Instrumentação Agropecuária: projeto excelência na pesquisa tecnologia. São Carlos.

EMPRESA BRASILEIRA DE PESQUISA AGROPECUÁRIA (2003b). Secretaria de Gestão Estratégica. Pesquisa, desenvolvimento e inovação para o agronegócio brasileiro: cenários 2002-2012. Brasília, 92 p.

EMPRESA BRASILEIRA DE PESQUISA AGROPECUÁRIA (2004). Secretaria de Gestão Estratégica. Homepage institucional. Disponível em <http://www.cnpdia.embrapa.br/>. Acesso em: 29 de abr.

EMPRESA BRASILEIRA DE PESQUISA AGROPECUÁRIA (2004). Homepage institucional. Disponível em <http://www.embrapa.br/embrapa/index.htm>. Acesso em: 23 de abr. 
FERREIRA, A.B.H. (1986). Novo Dicionário da Língua Portuguesa. Rio de Janeiro: Nova Fronteira.

FRESNEDA, P.S.V. (2002). Modelo de gestão estratégica da Embrapa: estudo de caso. I Fórum Balanced Scorecard Brasil, 41 p.

GARVIN, D.A. (1995). Leveraging Processes for Strategic Advantage. Harvard Business Review, p.77-90, Sep./Oct.

GARVIN, D.A. (1998). The processes of organization and management. Sloan Management Review, p.33-50, Summer.

GIL, A.C. (2000). Técnicas de pesquisa em economia e elaboração de monografias. São Paulo: Atlas.

GONÇALVES, J.E.L. (1997). Os novos desafios da empresa do futuro. RAE - Revista de Administração de Empresas, São Paulo, v.37, n.3, p.10-19, jul./set.

GONÇALVES, J.E.L. (1998). A necessidade de reinventar as empresas. RAE - Revista de Administração de Empresas, São Paulo, v.38, n.2, p.6-17, abr./jun.

GONÇALVES, J.E.L. (2000a). As empresas são grandes coleções de processos. RAE Revista de Administração de Empresas. v.40, n.1, p.6-19, jan./mar.

GONÇALVES, J.E.L. (2000b). Processo, que processo? RAE - Revista de Administração de Empresas, São Paulo, v.40, n.4, p.8-19, out./dez. 
GOOLD, M. CAMPBELL, A. (2002). Do you have a well-designed organization? Harvard Business Review, v.80, n.2, p.117-124.

GRAHAM, M.; LeBARON, M. (1994). The horizontal revolution. San Francisco: Jossey-Bass.

GULLEDGE JR.; SOMMER, R.A. (2002) Business process management: public sector implications. Business Process Management Journal, v.8, n.4, p.364-376.

HAMMER, M.; CHAMPY, J. (1994). Reengenharia: revolucionando a empresa em função dos clientes, da concorrência e das grandes mudanças da gerência. Tradução de Ivo Korytowski. Rio de Janeiro: Campus.

HAMMER, M. (1997) Além da reengenharia: como organizações orientadas para processos estão mudando nosso trabalho e nossas vidas. Tradução de Ana Beatriz Rodrigues e Priscilla Martins Celeste. Rio de Janeiro: Campus.

HAMMER, M.; STANTON, S. (1999). How process enterprises really work. Harvard Business Review, v.77, n.6, p.108-118, nov./dec.

HAMMER, M. (1998). Empresa voltada para processos. HSM Management, n.9, ano 2, jul./ago.

HARRINGTON, H.J. (1993). Aperfeiçoando processos empresariais. São Paulo: Makron Books. 
HARRINGTON, H.J. (1991). Business process improvement. New York: McGraw Hill.

HAVE, S.T. et al. (2003). Modelos de gestão: o que são e quando devem ser usados. Tradução de Brasil Ramos Fernandes. São Paulo: Peason Prentice Hall.

HERNADEZ, J.M.C.; CALDAS, M.P. (2001). Resistência à mudança: uma revisão crítica. RAE -Revista de Administração de Empresas, São Paulo, v.41, n.2, p.31-45, abr.jun.

KAPLAN, R.S.; NORTON, D.P. (1997). A estratégia em ação: balanced scorecard. Tradução de Luiz Euclydes Trindade Frazão Filho. Rio de Janeiro: Campus.

KAPLAN, R.S.; NORTON, D.P. (2000). Organização orientada para a estratégia: como as empresas adotam o balanced scorecard prosperam no novo ambiente de negócios. Tradução de Afonso Celso da Cunha Serra. Rio de Janeiro: Campus.

KAPLAN, R.S.; NORTON, D.P. (2004). Mapas estratégicos: convertendo ativos intangíveis em resultados tangíveis. Rio de Janeiro: Campus.

KOTTER, J.P. (1997). Liderando mudança.Rio de Janeiro: Campus.

MAGANELLI, R.L.; KLEIN, M.M. (1995). Manual de reengenharia: um guia passo a passo para a transformação da sua empresa. Rio de Janeiro: Campus.

MANO, C. (2003). Sem essa de cada um na sua: como a gestão por processos está mudando a rotina e os resultados da Johnson e Johnson no Brasil. Revista Exame. São Paulo, edição 800, p.74-77. 
MENDES, P.J.V.; GUIMARÃES, T. de A. (2002). Gestão Flexibilidade organizacional em ambiente de P\&D: alcance e limites da divisão do trabalho por processos. In: ENCONTRO NACIONAL DOS PROGRAMAS DE PÓS-GRADUAÇÃO EM ADMINISTRAÇÃO, 26, 2002, Salvador. Anais eletrônicos...Disponível em: <http://www.anpad.org.br/frame_enanpad2002.html>. Acesso em: 10 mai. 2004.

MINTZBERG, H.; AHLSTRAND, B e LAMPEL, J. (2000). Safári de estratégia: um roteiro pela selva do planejamento estratégico. Tradução de Nivaldo Montingelli Júnior. Porto Alegre: Bookman.

OSTROFF, F.; SMITH, D. (1992). The horizontal organization. The McKinsey Quarterly, n.1.

PORTER, M.W. (1996). What is strategy? Harvard Business Review, p.61-78, nov./dec.

REY, L. (1993). Planejar e redigir trabalhos científicos. São Paulo: Editora Edgard Blücher.

RIBEIRO, O.R.; VASCONCELOS, J.R.P.; RAMALHO ,J. (2002). Consórcio Organizacional para promoção e apoio a atividades de $P \& D$ e transferência de tecnologia agropecuária. Brasília: SSE, 51 p.

ROBBINS, S.P. (2002). Comportamento organizacional. Tradução de Reynaldo Cavalheiro Marcondes. São Paulo: Prentice Hall. 
RODRIGUES, C.H. (2002). Empowerment e estágios evolutivos das áreas de gestão: estudos de casos em empresas manufatureiras. 115 p. Dissertação (Mestrado). Escola de Engenharia de São Carlos, Universidade de São Paulo, São Carlos, 2002.

RODRIGUES, C. H.; SANTOS, F. C. A. (2001). Empowerment: ciclo de implementação, dimensões e tipologia. Gestão \& Produção, v.8, n.3, p.237-249, dez.

SALERNO, M.S. (1999). Projeto de organizações integradas e flexíveis: processos, grupos e gestão democrática via espaços de comunicação-negociação. São Paulo: Atlas.

SENTANIN, O.F. (2003). Gestão por processos em uma empresa de P\&D. In: ENCONTRO NACIONAL DE ENGENHARIA DE PRODUÇÃO, 23., 2003, Ouro Preto. Anais... Ouro Preto: Abepro.

SILVA, J.R.G.da; VERGARA, S.C. (2002). Mudança organizacional e as múltiplas relações que afetam a reconstrução das identidades dos indivíduos. In: ENCONTRO NACIONAL DOS PROGRAMAS DE PÓS-GRADUAÇÃO EM ADMINISTRAÇÃO, 26, 2002, Salvador. Anais eletrônicos...Disponível em: <http://www.anpad.org.br/frame_enanpad2002.html>. Acesso em: 10 mai. 2004.

SILVA, L.C.DA (2003). O balanced scorecard e o processo estratégico. Caderno de Pesquisa em Administração. São Paulo, v.10, n.4, p.61-73, out/dez.

SLACK, N. et al. (1999). Administração da Produção. São Paulo: Atlas.

STEWART, T. (1992). The search for the organization of tomorrow. Fortune, v.125, n.10, p.92-98, may. 
THIOLLENT, M. (2003). Metodologia de pesquisa-ação. São Paulo: Cortez.

UBEDA, C.L. (2003). A gestão de competências em uma empresa de pesquisa e desenvolvimento: um estudo de caso. 123 p. Dissertação (Mestrado) - Escola de Engenharia de São Carlos, Universidade de São Paulo, São Carlos. 2003.

UNIVERSIDADE DE SÃO PAULO. Escola de Engenharia de São Carlos. Serviço de Biblioteca. (2002). Diretrizes para elaboração de dissertações e teses na EESC-USP. 3.ed. São Carlos.

VALERIANO, D.L. (1998). Gerência em projetos. São Paulo: Makron Books.

VALERIANO, D.L. (2001). Gerenciamento estratégico e administração por projetos. São Paulo: Makron Books.

VIEIRA, M.M.F.; ZOUAIN, D.M. (2004). Pesquisa qualitativa em administração. Rio de Janeiro: Editora FGV.

WOOD JR., T. (1995). Mudança organizacional: aprofundando temas atuais em administração de empresas. São Paulo: Atlas.

YIN, R.K. (1989). Case study research: design and methods. Beverly Hills: Sage. 


\section{APÊNDICE 1}

\section{Produtos e Tecnologias da}

\section{Embrapa Instrumentação Agropecuária}

(fonte: <http://www.cnpdia.embrapa.br/>) 


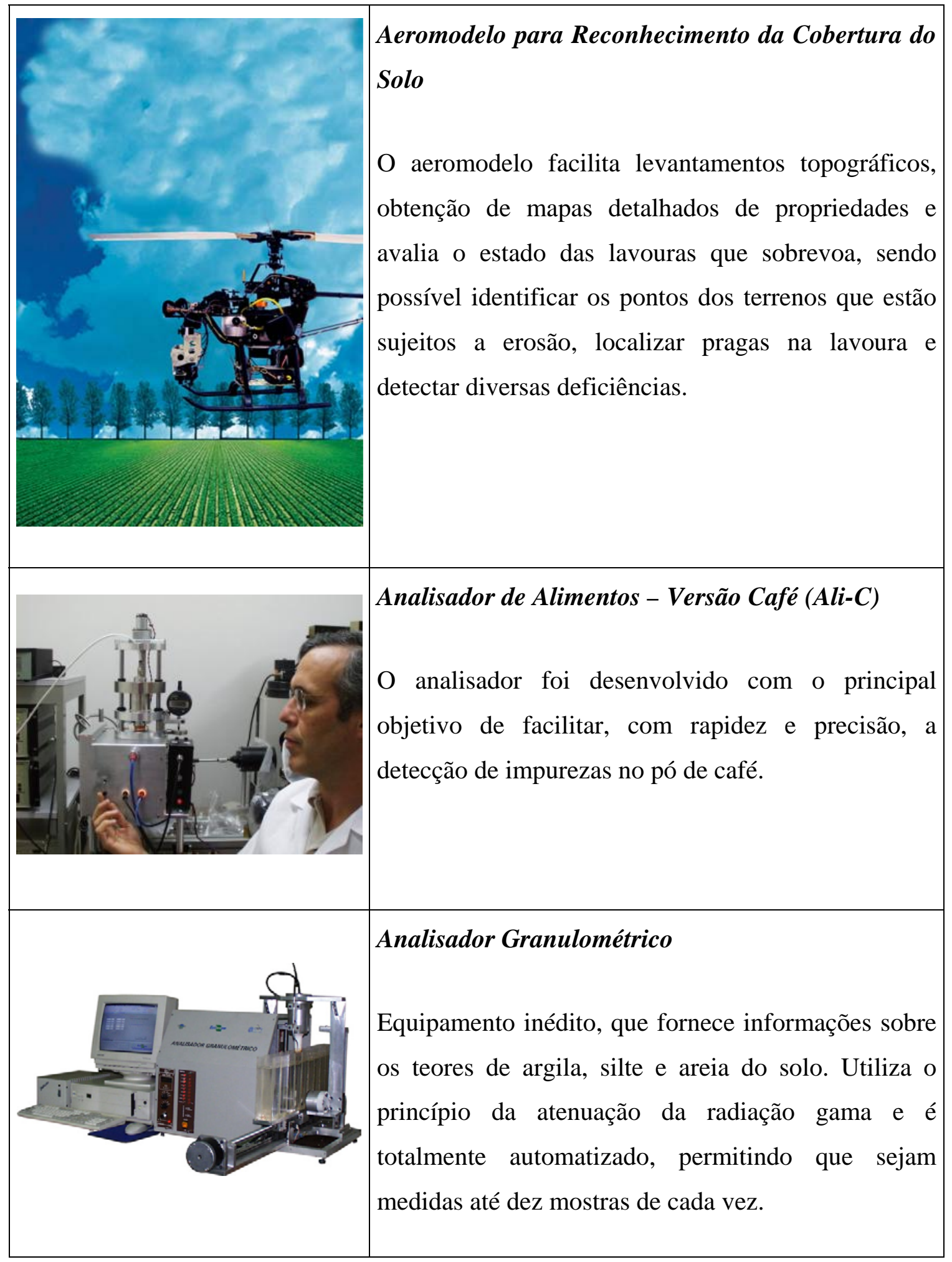




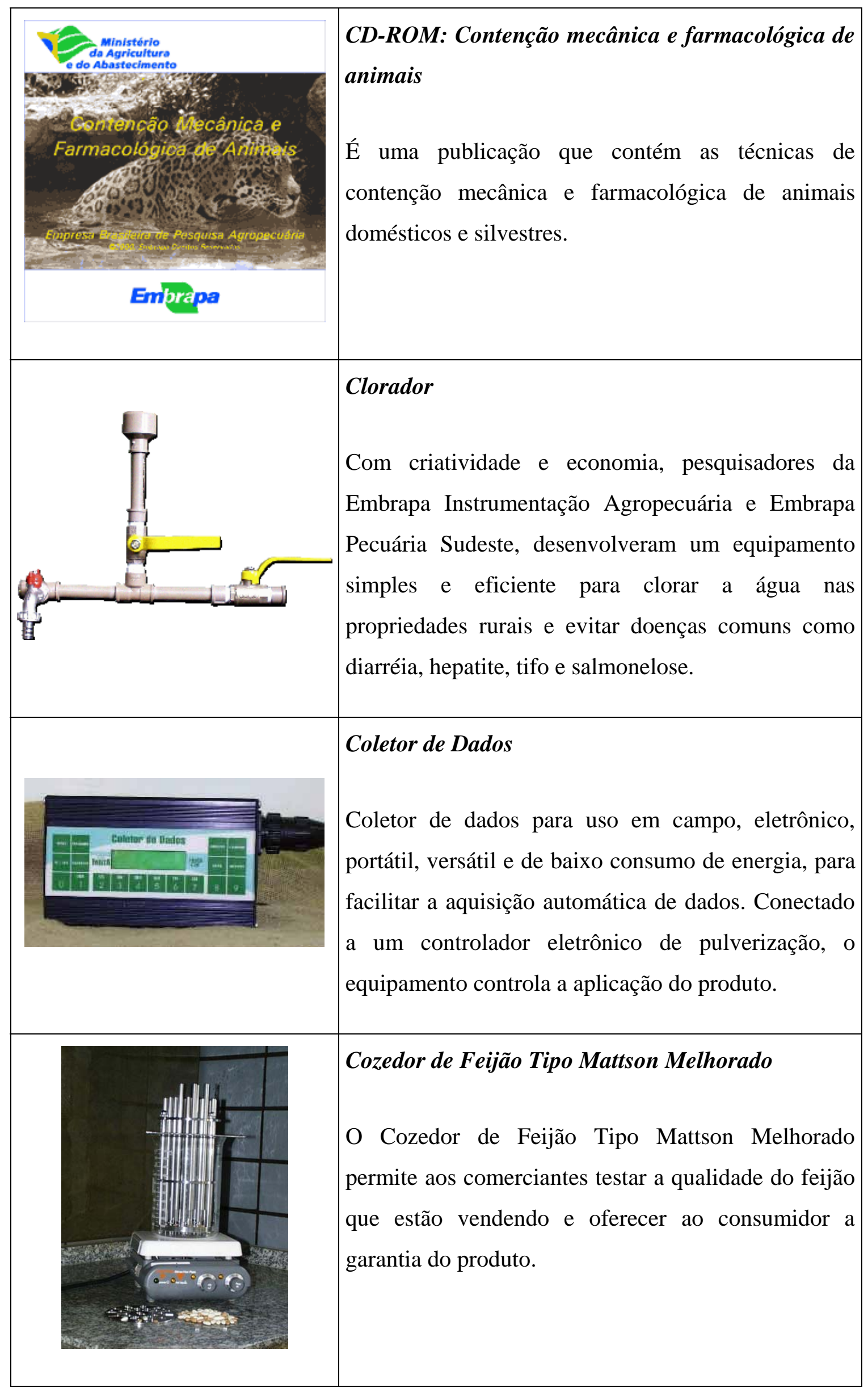




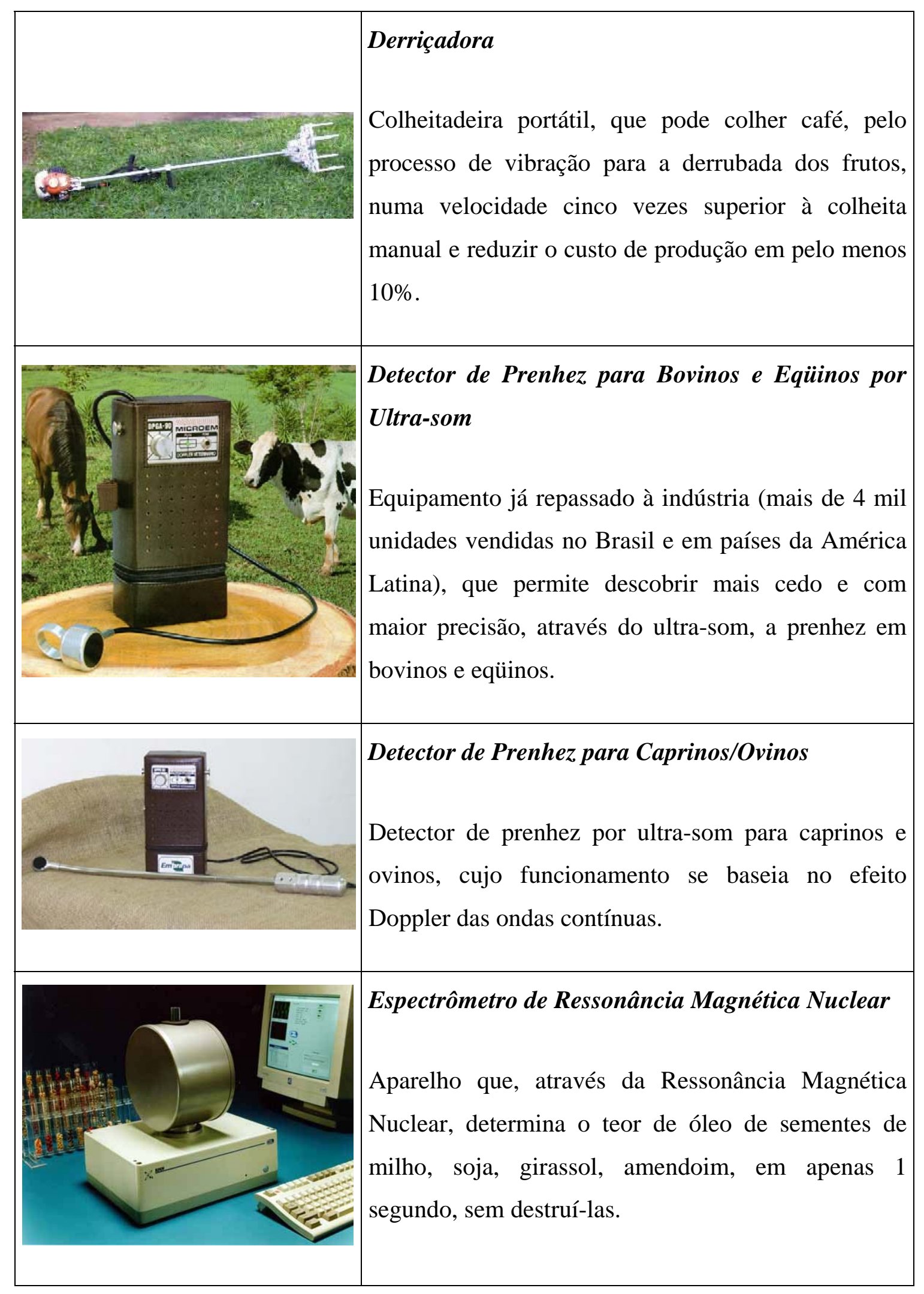




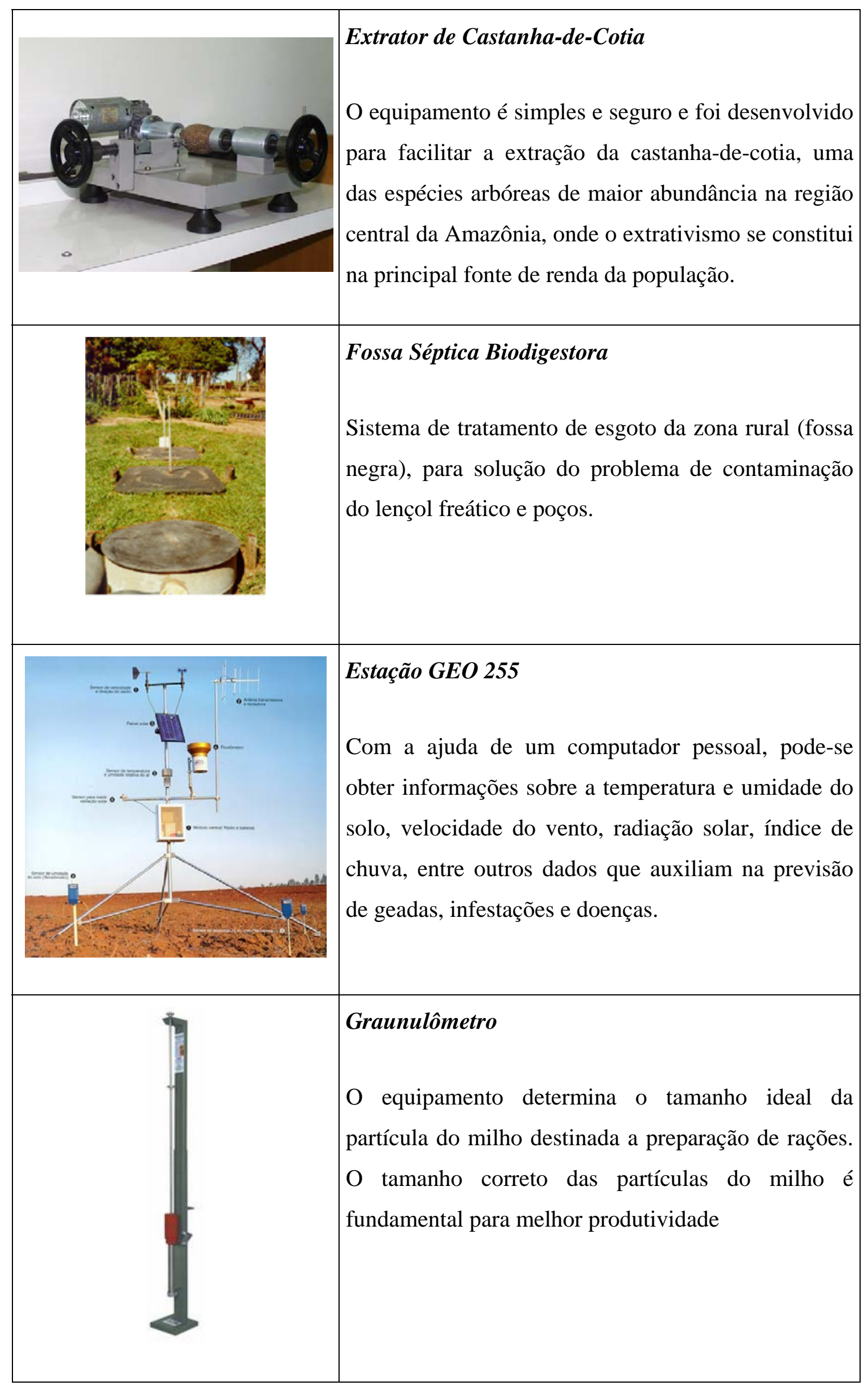




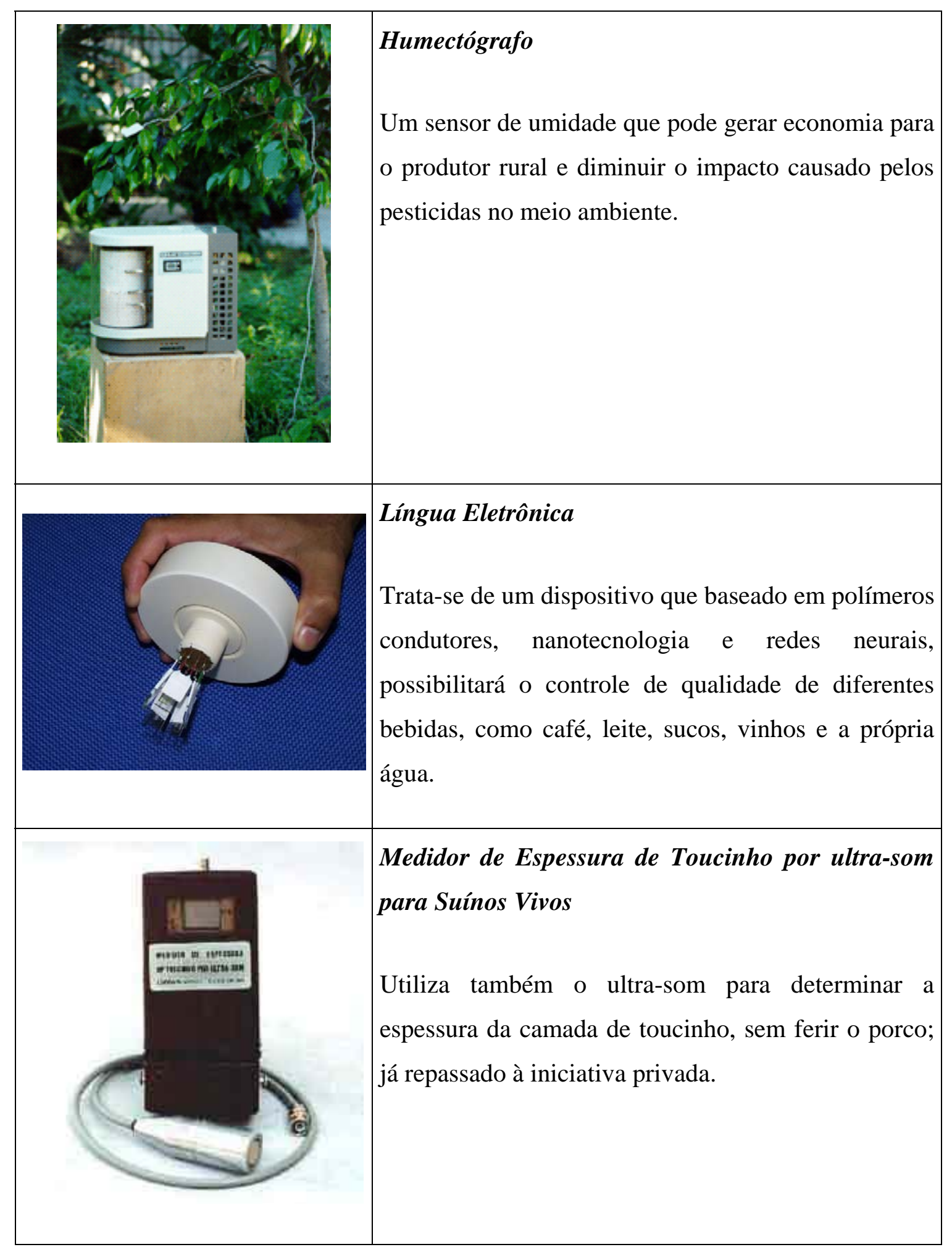




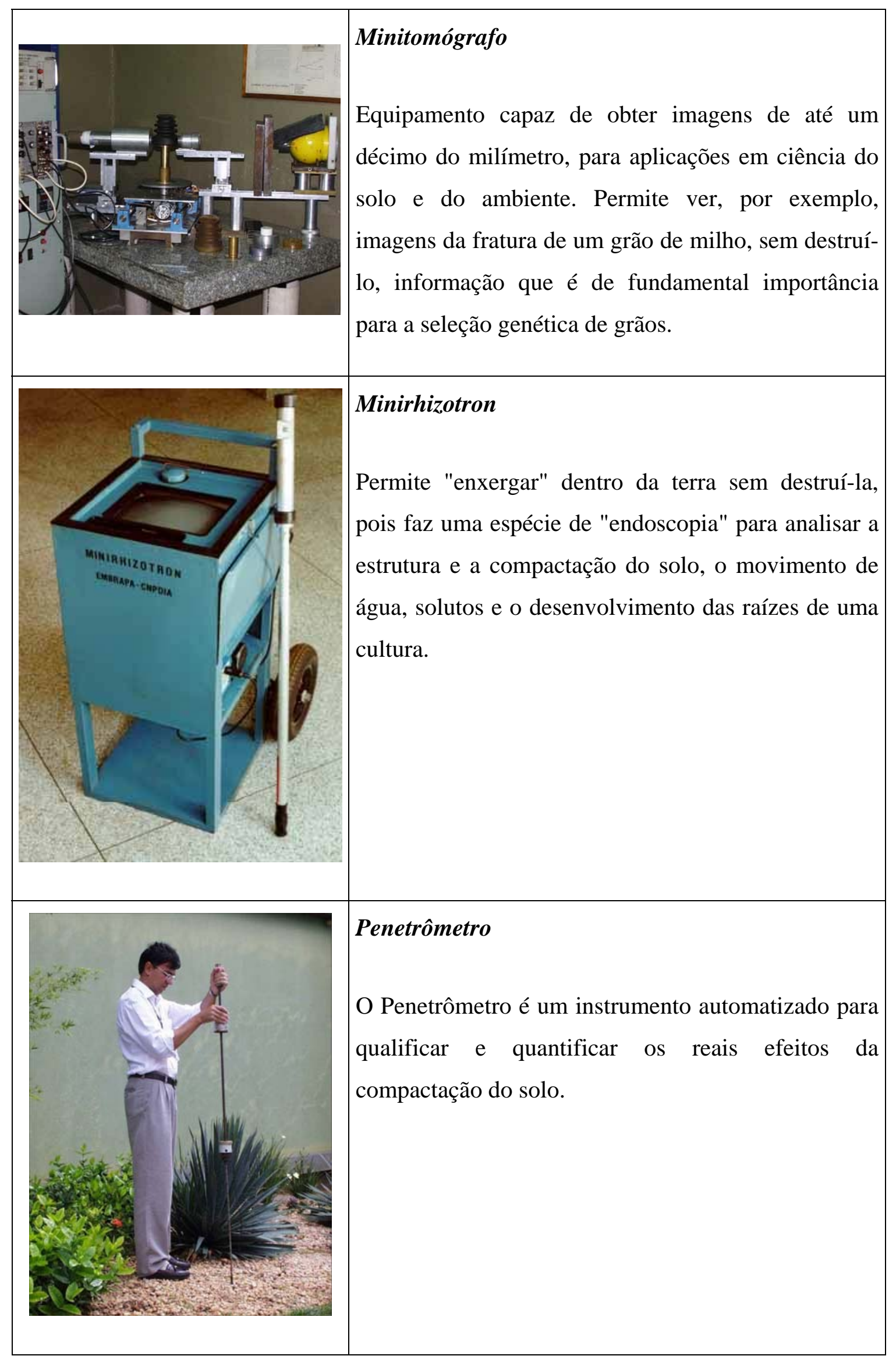




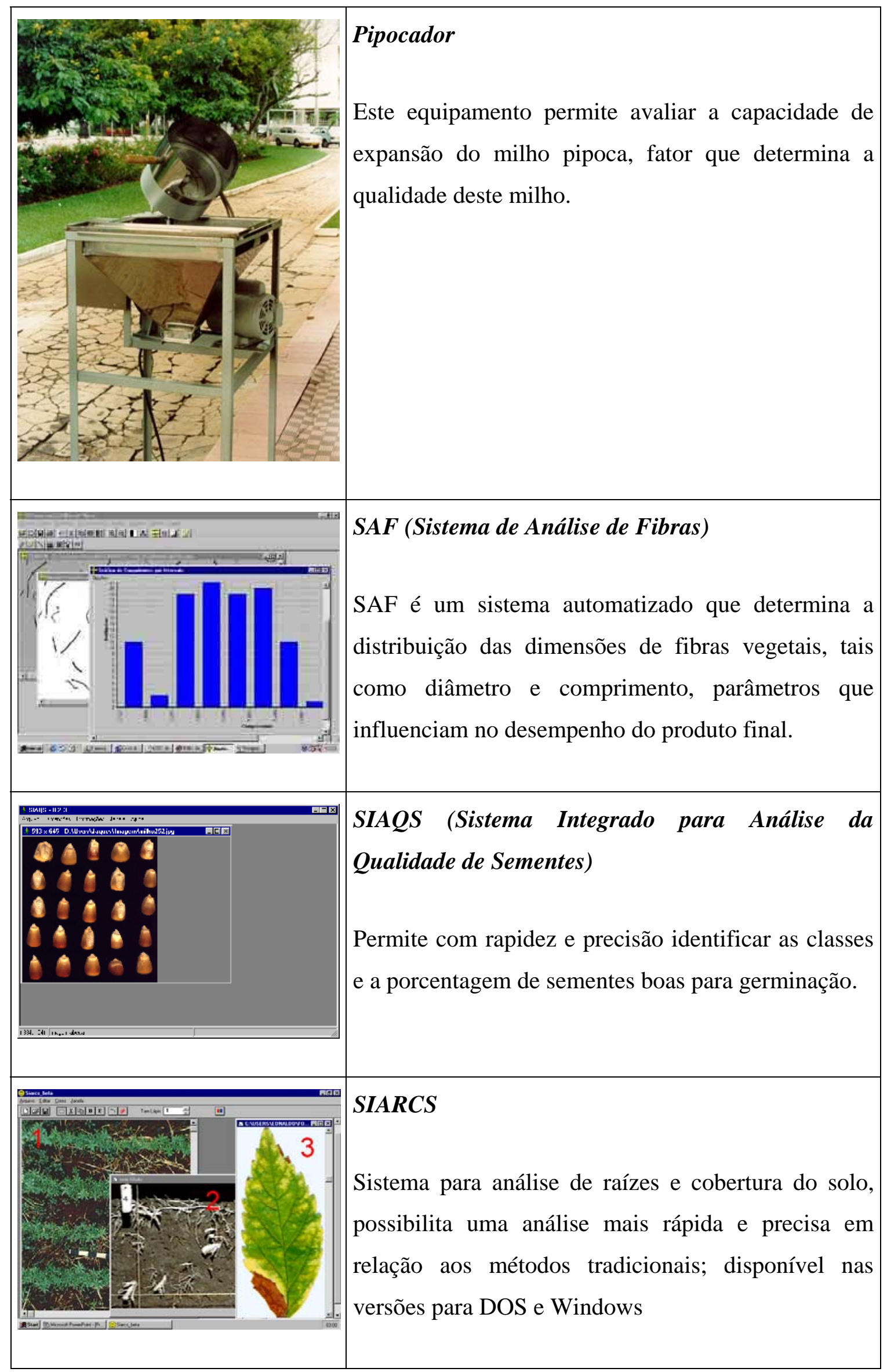




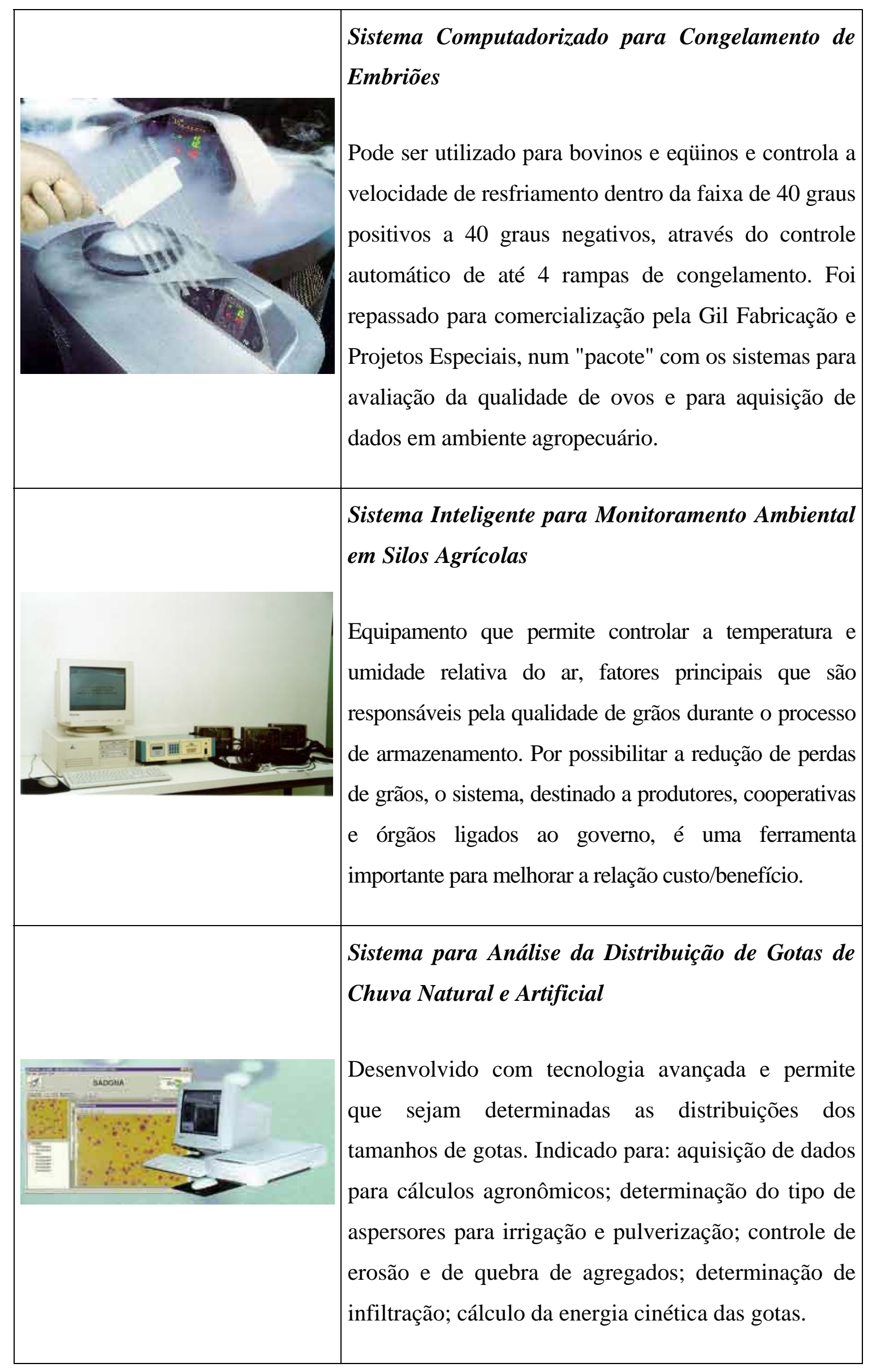




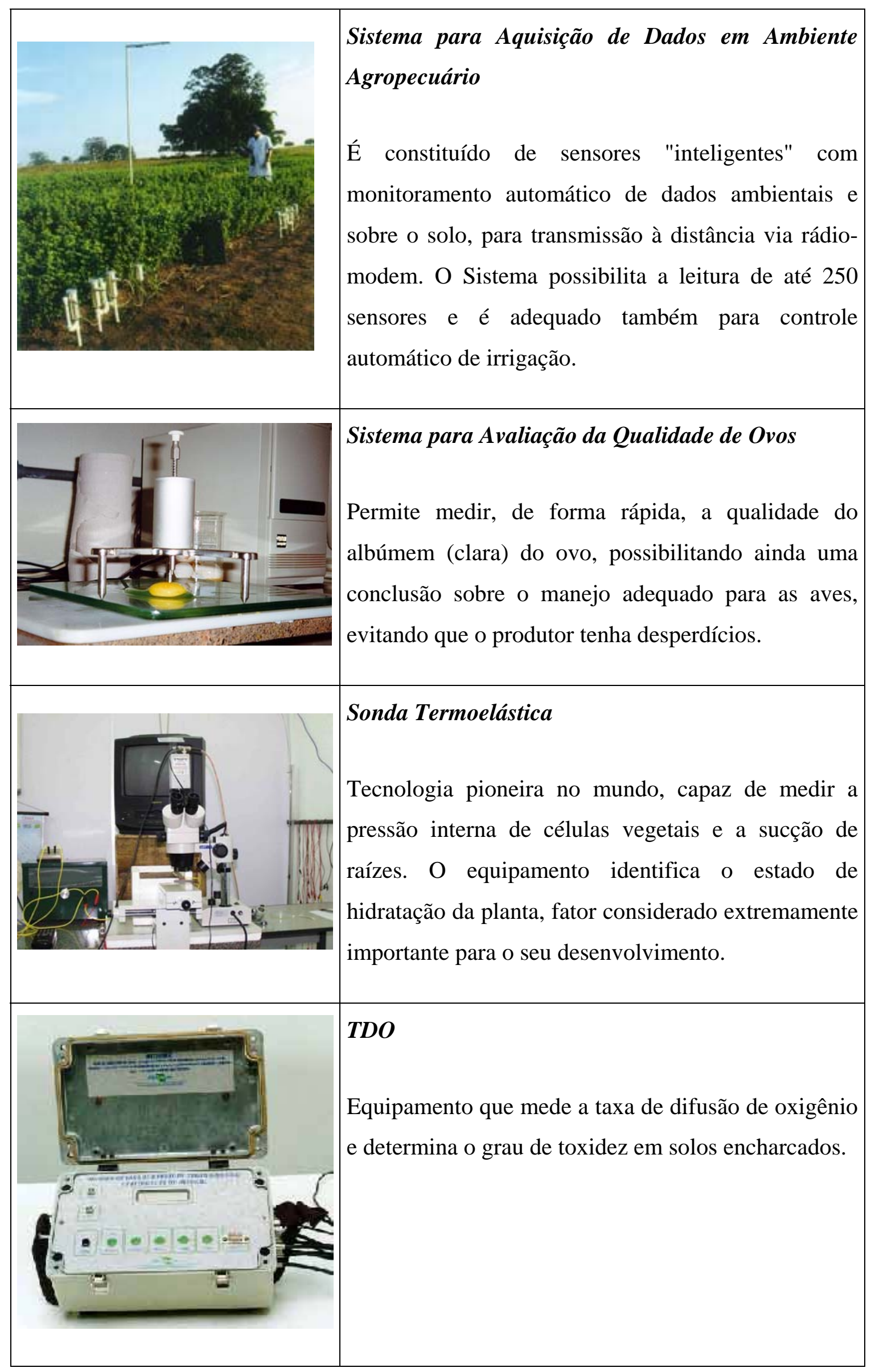




\begin{tabular}{|c|c|}
\hline $\mathrm{N}_{0}$ & $\begin{array}{l}\text { Tomógrafo Micrométrico } \\
\text { Obtém imagens, de forma não destrutiva, de amostras } \\
\text { de solo, que permitam visualizar detalhes com } \\
\text { medidas iguais ou menores que } 100 \mathrm{~mm} \text {. Esse } \\
\text { tomógrafo permite a avaliação de poros e partículas } \\
\text { com tamanhos compatíveis com essa dimensão. }\end{array}$ \\
\hline & $\begin{array}{l}\text { Tomógrafo Portátil de Campo } \\
\text { O equipamento permite a análise detalhada de solos - } \\
\text { compactação, raízes e umidade - e troncos de árvores } \\
\text { com até } 30 \mathrm{~cm} \text { de diâmetro. Permite também o estudo } \\
\text { de estruturas de concreto. A técnica tomográfica, } \\
\text { além de não destruir a amostra, permite a } \\
\text { visualização no próprio local. }\end{array}$ \\
\hline & $\begin{array}{l}\text { Veículo de apoio à aquisição de dados em ambiente } \\
\text { agrícola } \\
\text { Sua função é apoiar a aquisição de dados em campo. } \\
\text { O veículo leva equipamentos portáteis, utilizados } \\
\text { para medir parâmetros de planta em vários estágios, } \\
\text { entre eles, o vigor e o estresse. }\end{array}$ \\
\hline
\end{tabular}




\section{APÊNDICE 2}

Cartaz divulgado às unidades da Embrapa sobre Banco de Dados de Boas Práticas 


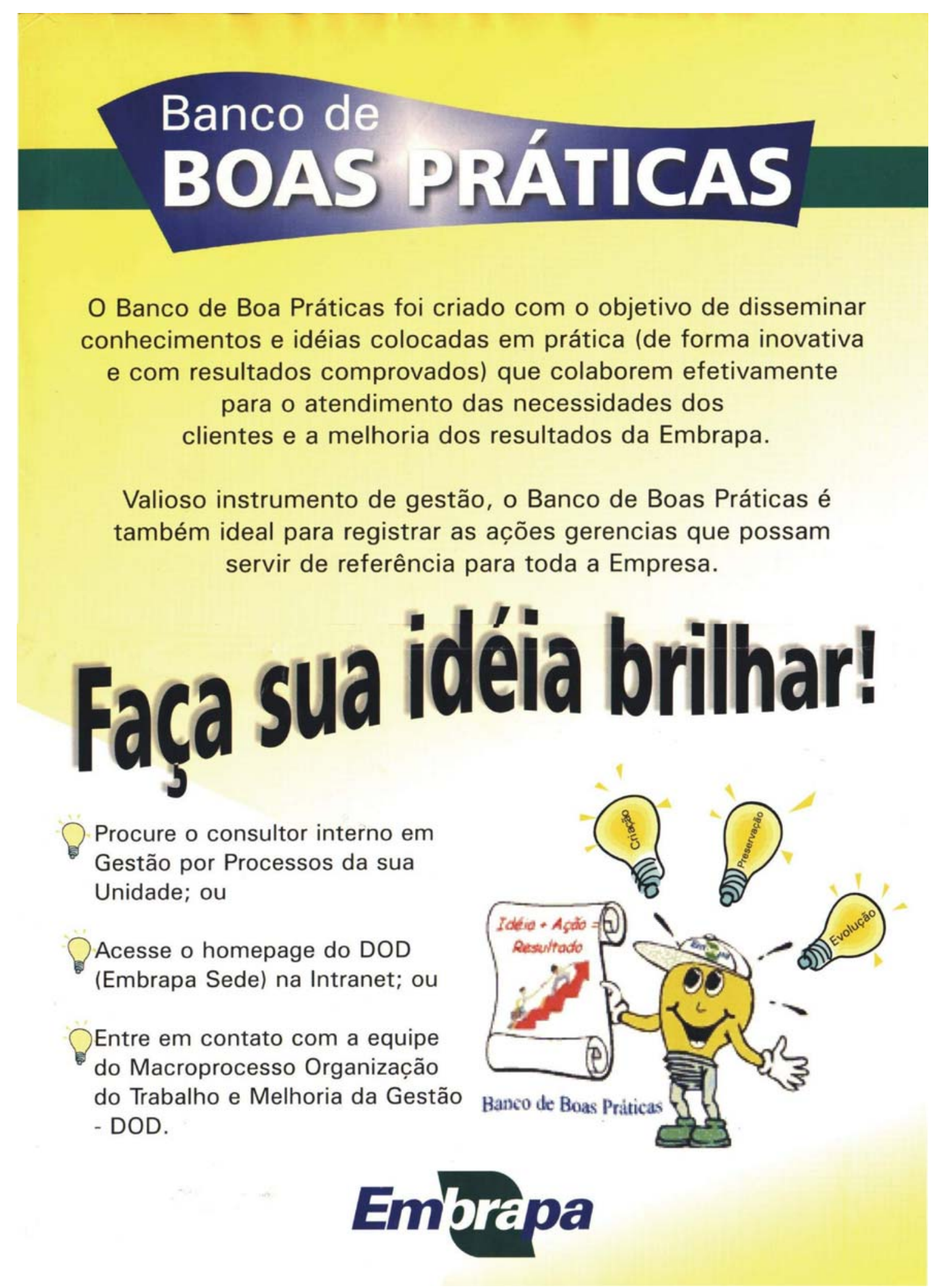

